\title{
Molecular Mechanism of SRY Action during Testicular Differentiation in The Mouse.
}

Ghazaleh Tavallaee

\author{
Biology Department \\ McGill University \\ Montreal \\ Quebec
}

August 2007

A thesis submitted to McGill University in partial fulfillment of the requirements for the degree of Master of Sciences.

(c) G. TAVALLAEE, 2007 


$\begin{array}{ll}\begin{array}{l}\text { Library and } \\ \text { Archives Canada }\end{array} & \begin{array}{l}\text { Bibliothèque et } \\ \text { Archives Canada }\end{array} \\ \begin{array}{l}\text { Published Heritage } \\ \text { Branch }\end{array} & \begin{array}{l}\text { Direction du } \\ \text { Patrimoine de l'édition }\end{array} \\ \begin{array}{l}\text { 395 Wellington Street } \\ \text { Ottawa ON K1A 0N4 } \\ \text { Canada }\end{array} & \begin{array}{l}\text { 395, rue Wellington } \\ \text { Ottawa ON K1A 0N4 } \\ \text { Canada }\end{array}\end{array}$

Your file Votre référence ISBN: 978-0-494-51350-7

Our file Notre référence

ISBN: 978-0-494-51350-7

NOTICE:

The author has granted a nonexclusive license allowing Library and Archives Canada to reproduce, publish, archive, preserve, conserve, communicate to the public by telecommunication or on the Internet, loan, distribute and sell theses worldwide, for commercial or noncommercial purposes, in microform, paper, electronic and/or any other formats.

The author retains copyright ownership and moral rights in this thesis. Neither the thesis nor substantial extracts from it may be printed or otherwise reproduced without the author's permission.
AVIS:

L'auteur a accordé une licence non exclusive permettant à la Bibliothèque et Archives Canada de reproduire, publier, archiver, sauvegarder, conserver, transmettre au public par télécommunication ou par l'Internet, prêter, distribuer et vendre des thèses partout dans le monde, à des fins commerciales ou autres, sur support microforme, papier, électronique et/ou autres formats.

L'auteur conserve la propriété du droit d'auteur et des droits moraux qui protège cette thèse. $\mathrm{Ni}$ la thèse ni des extraits substantiels de celle-ci ne doivent être imprimés ou autrement reproduits sans son autorisation.
In compliance with the Canadian Privacy Act some supporting forms may have been removed from this thesis.

While these forms may be included in the document page count, their removal does not represent any loss of content from the thesis.
Conformément à la loi canadienne sur la protection de la vie privée, quelques formulaires secondaires ont été enlevés de cette thèse.

Bien que ces formulaires aient inclus dans la pagination, il n'y aura aucun contenu manquant.

\section{Canada}




\section{Table of contents}

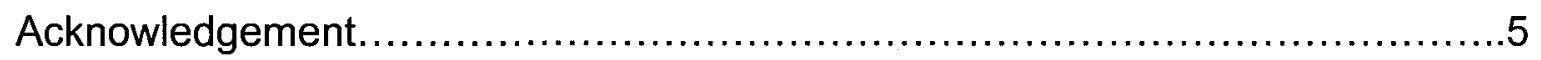

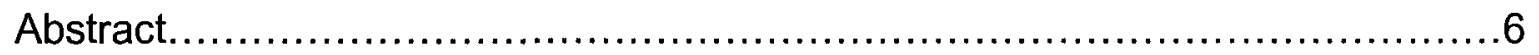

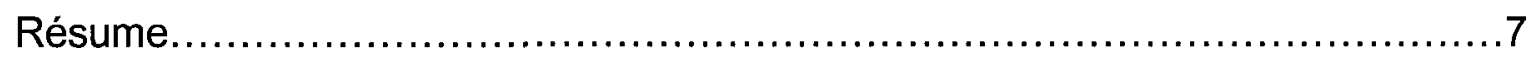

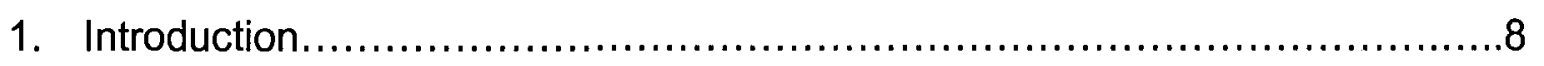

1.1. Mechanisms of sex determination in non-mammalian species..............9

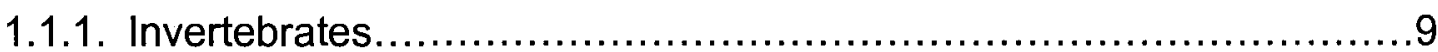

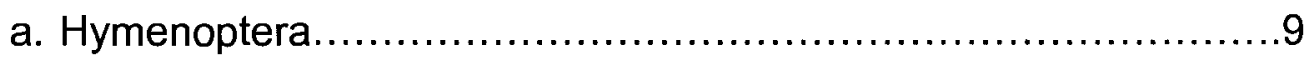

b. Dipterans (Drosophila melanogaster) .............................10

c. Nematodes (Caenorhabditis elegans) ..............................10

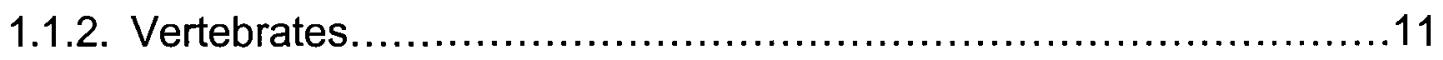

a. Reptiles........................................................ 11

b. Amphibians.......................................................

c. Fish................................................................

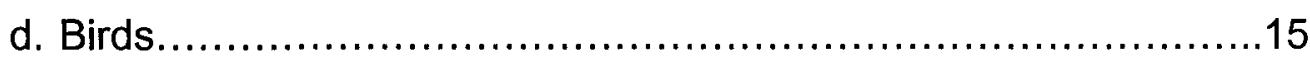

1.2. Mechanisms of sex determination in mammals........................16

1.2.1. Morphological Gonadal Organogenesis..............................17

1.2.2. Germ Cells................................................................... 20

a. Origin and migration...........................................20

b. Differentiation of PGCs and somatic cells........................21

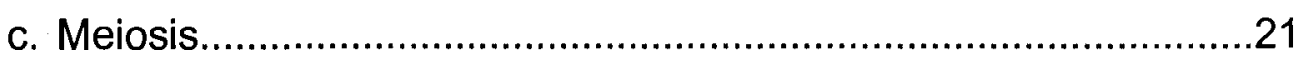

1.2.3. Ductal System: Development and Differentiation......................22

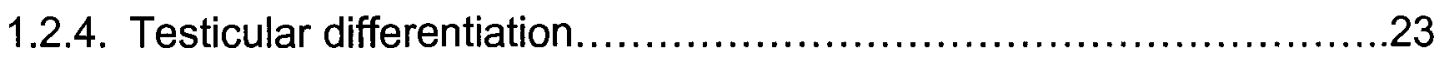

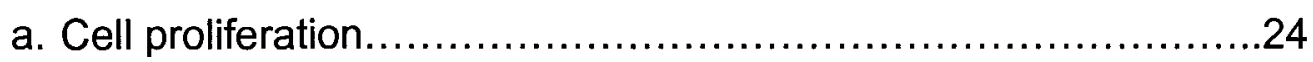

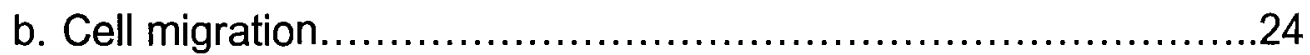

c. Sertoli cell differentiation............................................ 25

d. Peritubular myoid cells............................................27

e. Testis cord formation...............................................

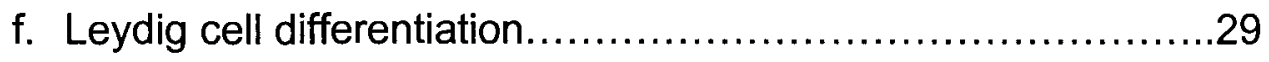

g. Vascular and other interstitial cells............................30 


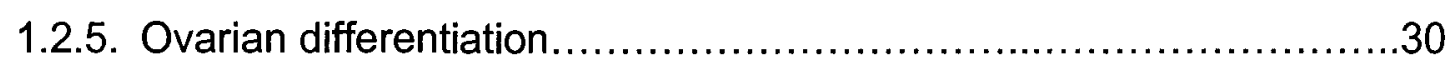

Formation of primordial follicles....................................... 32

1.3. Molecular genetics of gonadal differentiation.............................33

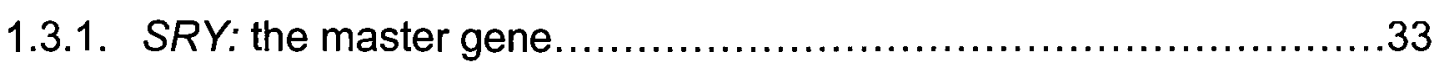

1.3.2. Other genes involved in gonadal sex differentiation ...................36

a. Bipotential stage ............................................... 36

SF1 .............................................................

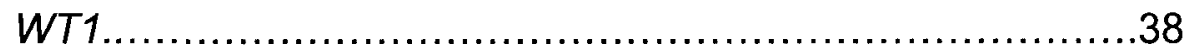

b. Genes involved in testicular differentiation downstream of $S R Y . . .40$ SOX9............................................................... 40

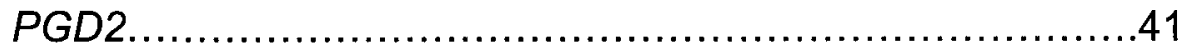

MIS ......................................................... 42

FGF9........................................................... 43

c. Other important genes............................................44

d. Genes involved in ovarian pathway............................44

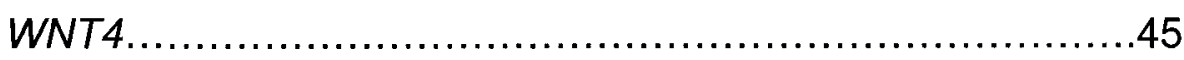

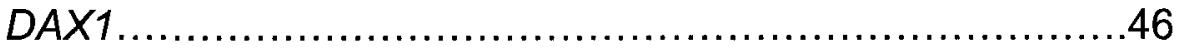

FST ...................................................... 48

FOXL2 ....................................................... 49

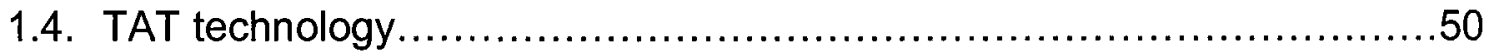

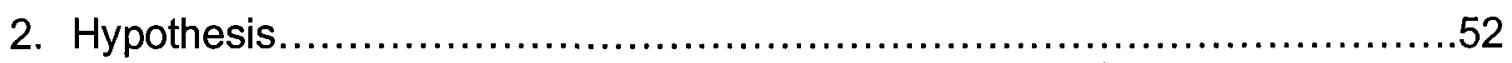

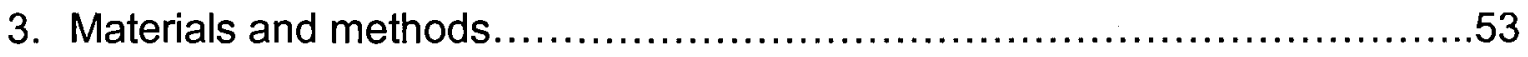

3.2. Expression and purification of TAT-fusion proteins ........................53

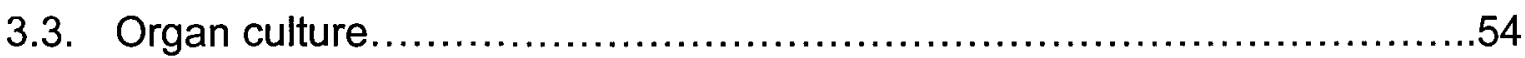

Tissue collection..................................................... 54

Organ Culture ........................................................... 54

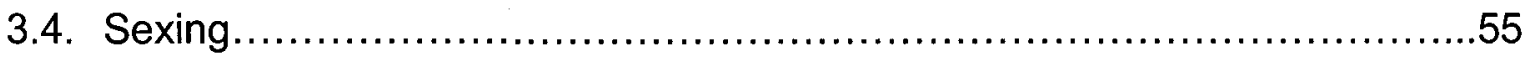

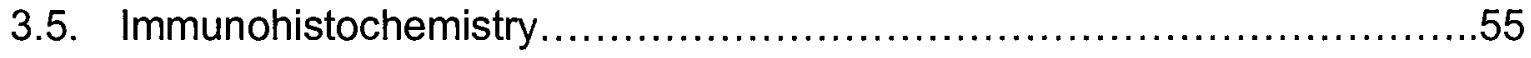

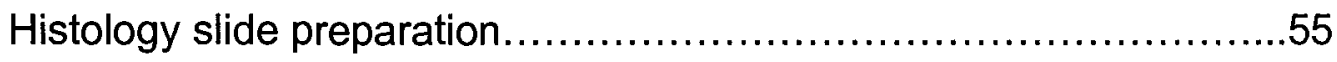




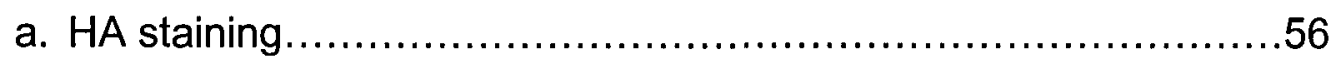

b. MIS-laminin double staining.....................................56

c. [SOX9 or SRY]-MIS double staining.............................56

Mounting and Imaging..................................................

3.6. TdT-mediated dUTP nick end labeling (TUNEL) assay ................57

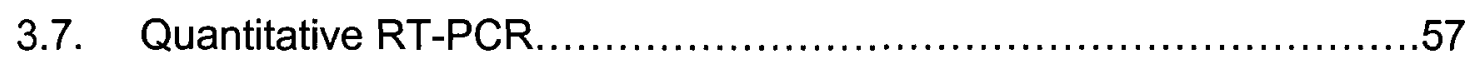

a. Total RNA purification.........................................57

b. cDNA synthesis.................................................... 58

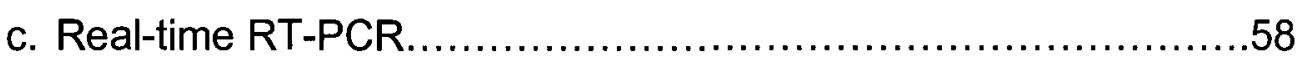

d. Statistical analysis.................................................59

4. Results. .60

4.1. Testis cord formation and Sertoli cell differentiation in culture.........60

a. In vivo control..................................................... 60

b. Untreated control ...............................................61

c. Treatment with TAT-HMG protein .............................61

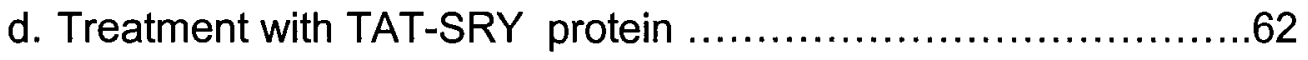

e. Treatment with DMSO alone.....................................62

f. Treatment with PGD2 ...............................................62

4.2. TAT- fusion protein incorporation into gonad..........................63

4.3. Time course of testicular differentiation in culture ......................63

a. Untreated control................................................63

b. Treatment with $6 \mu \mathrm{g} / \mathrm{ml}$ TAT-HMG..................................64

4.4. Effects of TAT-HMG on gene expression during testicular differentiation..............................................................64

4.5. Effects of DMSO alone on gene expression during testicular differentiation..................................................................65

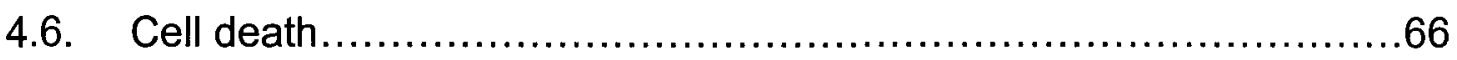

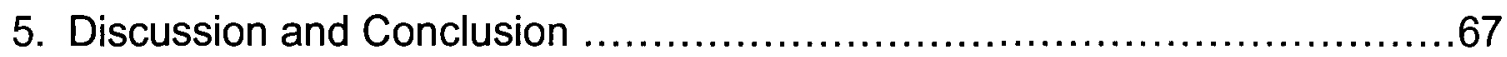

5.1. Sertoli cell differentiation and testis cord formation ...................67 
5.2. DMSO inhibits testicular differentiation...................................68

5.3. TAT-SRY failed to induce testicular differentiation......................69

5.4. TAT-HMG rescued Sertoli cell differentiation but not testis cord

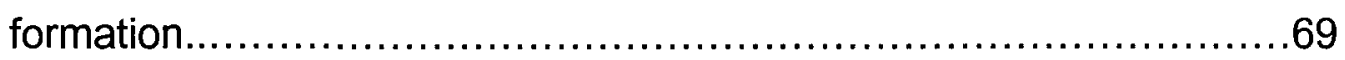

5.5. Prolonged SRY expression and delay in Sertoli cell differentiation.....71

5.6. Association of Fgf9 and Wnt4 transcript levels with testicular differentiation in culture .................................................. 71

5.7. Migration of mesonephric cells into developing gonad.................72

5.8. Conclusions................................................................

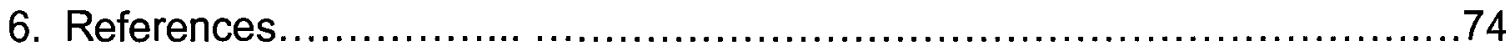

7. Figures \& figure legends........................................................ 


\section{Acknowledgement}

Dedicated to my parents, Nahid Mahmoodzadeh and Mahdi Tavallaee, with love,,

My special thanks to my husband, Arash Golshan, for all of his supports, my brother in law, Saeed Hassanzadeh, for his helps.

I am grateful to Dr. Teruko Taketo for her brilliant supervision, patience, friendship and great advises during my research period. I really enjoyed and appreciated friendship and kindness of all the people in $\mathrm{H} 6$ floor Royal Victoria Hospital, McGill University, specially, Michele Villemure and Cristina Ene our lab members, Lucia Fallavolita for her friendship and the French translation of the abstract of my thesis and Shirley Cote for her friendship.

I am grateful to Dr. Junjian Chen (McGill University) for allowing and helping me to use his real-time PCR facility. I also thank Luci Hamel and Joyce Rocha (McGill University) for their advices on real-time RT-PCR.

I would like to thank my sister, Haleh Tavallaee, my brother Amirali Tavallaee, and my niece and nephew, Helya and Kouroush Hassanzadeh. My special thanks to my parent's in-laws, Zahra Meshkinian and Fereidoun Golshan, brother and sister in law Syavash Golshan and Sanaz Golshan for their helps. 


\section{Abstract}

SRY (Sex determining Region of $Y$ chromosome) is the master gene initiating testis determination in mammals. To shed light on the molecular mechanism of $S R Y$ action during testicular differentiation, we examined the effects of TAT-HMG fusion protein on gonadal sex differentiation in culture. HMG is the DNA binding motif of SRY and "TAT" is a protein transduction domain. Each pair of CD1 mouse gonadal primordia at 11.5 days post coitum $(\mathrm{dpc})$ was cultured with or without TAT-HMG dissolved in dimethyl sulfoxide (DMSO) up to 3 days. Immunocytochemical labeling and Real-time RT-PCR of Sry, Sox9 and Mis indicated that DMSO blocked testicular differentiation, Sertoli cell differentiation and testis cords formation, downstream of SRY. TUNEL showed a massive mesenchymal cell death, which might be responsible for disruption of testis cord formation. Treatment with TAT-HMG rescued Sertoli cell differentiation, probably by up regulation of Sry, but not testis cord formation or cell death. 


\section{Résume}

SRY (la région déterminante du sexe dans le chromosome $Y$ ) est le gène maître inaugurant la détermination de testicule dans les mammifères. Pour éclaircir le mécanisme moléculaire d'action de SRY pendant la différenciation testicule, nous avons examiné les effets de TAT-HMG, une protéine de fusion, sur la différenciation du sexe gonadal en culture. HMG est le motif de SRY I'ADN liant, et TAT est un domaine de transduction de protéine. Chaque paire de CD1 primordia gonadal de souris à 11.5 jours poste coitum a été cultivé avec ou sans TAT-HMG dissous dans dimethyl sulfoxide (DMSO) jusqu'à 3 jours. L'étiquage immunocytochemical et RT-PCR en temps réel de SRY, SOX9 et MIS, indiquent que DMSO bloque la différenciation des testicules, la différenciation cellules des Sertoli, et la formation de corde testiculaire en aval de SRY. L'essai TUNEL a démontré une morte massive de cellules mesenchymales ce qui pourrait être responsable de l'interruption de la corde testiculaire. Le traitement avec TAT-HMG a secouru la différenciation cellules des Sertoli, probablement en augmentant SRY mais elle n'a pas affecté la formation de la corde testiculaire ou la mort des cellules. 


\section{Introduction}

Sex determination is a fundamental part of reproduction and a crucial process for the evolution and enrichment of the genome, so that it has been the subject of many studies across the species. Interestingly, data gathered by a variety of model organisms to date have shown a relative economy in the molecular regulation of sex determination. From insects to mammals, there is much to learn from the many mechanisms engaged in determining sexual fate (Manolakou et al., 2006). There exist various mechanisms involved in sex determination in the animal kingdom ranging from regulated mRNA splicing and intercellular ligandreceptor signaling to unknown temperature-sensitive mechanisms and the presence of distinct sex chromosomes. In most animal species the gonadal sex is portrayed by the phenotypic sex. In almost all mammalian species the male is easily distinguished from the female. Male and female differ in size (the male has larger bones and muscles), external genitalia, and sometimes skin, fur, and horns. The male is probably more aggressive than the female and has a different scent, an essential parameter in sexual attraction. These differences commence becoming apparent after differentiation of the embryonic gonad has taken place, since the gonadal hormones generally determine the somatic phenotypic sex (Byskov 1986). In most classes of vertebrates, except in mammals, the sex of animal exhibits great flexibility. The sex of amphibians and fish may change from male to female or through intersexuality to functional hermaphroditism known as natural sex reversal. The reversal or change of sex in different classes involves various factors such as genetic control mechanisms in Monopterus, changes in social organization in coral fish, changes in temperature in Rivulus, or changes in photoperiod (Chan, 1970; Baron et al., 2005). In mammals gonadal sex is normally a consequence of the genetic sex, which is established at fertilization and is evident in the chromosomal constitution (Byskov 1986). The first morphological signs indicating the sex of the fetus are seen in the gonadal anlagen, which are controlled by expression of certain genes on sex chromosomes at a certain time; SRY (Sex determining Region on $\mathrm{Y}$ chromosome) 
in $X Y$ gonads and its probable counterpart in $X X$ gonads (that is to be discovered). To date, the mechanisms that trigger the development of the gonads in both sexes are not well understood. Here, I will first review the mechanisms involved in the process of sex determination in some of the animal species studied up to now and then focus on sex determination in mammals in terms of morphology, gene expression and molecular interactions. Finally, I will represent my research project, results, discussion and conclusion.

\subsection{Mechanisms of sex determination in non-mammalian species}

\subsubsection{Invertebrates}

\section{a. Hymenoptera}

In the insect order of Hymenoptera (ants, bees and wasps) sex is determined by the fertilization of the egg: uniparental haploid males and biparental diploid females originate from unfertilized and fertilized eggs respectively. One of the best understood mechanisms is the single-locus complementary sex determination (slCSD), in which sex is determined by multiple alleles at a single locus. Heterozygotes at that sex locus develop as females whereas hemizygotes, and the odd case of homozygous diploids develop as males. In honeybees, for example, the sex locus has recently been identified as the complementary sex determiner (csd) gene that encodes an arginine-serine rich protein (Beye et al., 2003) whose function is required only in females. sl-CSD exhibits an evolutionary pressure against species with higher rates of inbreeding, due to one of its major faults. In most cases, mating leads to the creation of offspring with two different alleles at the sex locus (diploid females). However, a mating in such populations has higher probability of a union between a male and a female that share the same allele, a condition also known as a matched mating (Stalhut et al., 2004). In matched matings half the diploid offspring are predicted to turn out homozygous at the sex locus and develop as males rather than females. Diploid males in species 
with sl-CSD are generally sterile, unable to mate or are not viable (Zayed et al., 2004) and finally are eaten by the workers (Charlesworth et al., 2003).

\section{b. Dipterans (Drosophila melanogaster)}

In Drosophila melanogaster one single gene named sex-lethal $(s x /)$ makes the choice between male and female development and functions according to the ratio of $X$ chromosomes to autosomes (X:A ratio) (Penalva et al. 2003). Activation of the sxl gene early in development, through an "early" promoter in females, orchestrates a specific splicing of the $s x I$ mRNA. In males, standard splicing of the $s x I$ mRNA leads to a non-functional protein. It is only in females, through an autoregulatory feedback loop, that $s x$ stays active (Penalva et al. 2003, Keyes et al. 1992). SXL protein is a sequence-specific RNA-binding protein that interacts with RNA through an RNP motif (Lodish et al., 2001). SXL then regulates a series of other proteins that control female development, once again through the process of alternative splicing, leading finally to two alternative products of the doublesex gene (dsx), DSXF and DSXM (Lalli et al. 2003, De Loof et al. 1998). It is interesting to note that the $Y$ chromosome, present in males, takes no part in this entire process, and that its only use is to help successful completion of spermatogenesis later on in the differentiation of the male germ line.

\section{c. Nematodes (Caenorhabditis elegans)}

In nematodes the animal's sexual fate depends on the X:A ratio, and there is not even a $Y$ chromosome in males. C.elegans worms are special in that the choice lies between males with one $X$ chromosome and hermaphrodites with two. The $X: A$ ratio becomes effective through activation of several "X-signal elements", such as the SEX-1 (signal element on $X$ ) protein that acts on the transcription level and the FOX-1 (feminizing locus on $X$ ) protein that acts post-transcriptionally (Carmi et al. 1998). The two mentioned genes manage to suppress the levels of the XOL-1 (XO lethal) key protein (Meyer et al. 2000) in hermaphrodites. 
Expression or suppression of XOL-1 in turn activates a cascade of expression and suppression of several genes that results in the expression of TRA-1 (transformer 1) protein. TRA-1 is free to act in hermaphrodites and regulates the expression of several other genes (Kuwabara et al. 1992, Stothard et al 2003). This pathway involves several groups of gene products, some of which retain their active state in males and others in hermaphrodites. However, the hermaphrodites pose an interesting issue: they produce around 300 sperm in their fourth and final larval stage (L4), to use for self-fertilization when there are no males available (Kuwabara et al. 2001). This requires a careful regulation of the switching between the male and female differentiation of the same germ cells, without the benefit of the usual sex determination pathway and the "male" genes that normally regulate spermatogenesis are inactive anyway. Instead, a new series of genes take over at a specific stage of development and act in place of the HER-1 (Hermaphrodite 1) protein to inhibit tra-2 (transformer 2) and allow spermatogenesis to take place until the end of the L4 stage. Once this is over and the adult life onsets, a new series of genes take their place, tra-2 is once again active, and the adult hermaphrodite is free to continue with oogenesis for the rest of its life (Stothard et al 2003, Puoti et al. 2001)

\subsubsection{Vertebrates}

\section{a. Reptiles}

There are a considerable variety of sex determination patterns in different species of reptiles. For instance, most snakes possess a ZZ/ZW pairs of sex chromosomes, similar to the model mechanism for sex determination in birds. Lizards are even more complex, with different species having either a ZZ/ZW sex chromosome pair or a $X X X X Y$ system, similar to that observed in mammals (Graves et al. 2001, Maldonado et al. 2002). On the other hand, many species of reptiles, including most terrestrial turtles and all crocodilians and sea turtles examined to this date, have no discernible sex chromosomes, nor is their sex 
determined by the presence or absence of specific genes. Their sexual fate is determined by the temperature of the environment during the thermosensitive period (TSP) of incubation of the eggs, which regulates aromatase activity (Ferguson et al., 1982; Harvey et al., 1982).

Interestingly, a number of genes originally described as part of the genetic regulation of sex development in men and other mammals have also been detected in reptiles. For instance, in the sea turtle several genes so far related to mammalian sex determination are expressed, including $D A X 1$ (dosage-sensitive sex reversal 1), DMRT1 (doublesex- and mab-3-related transcription factor 1) and SOX9 (SRY related HMG box 9). Of particular importance is DAX1 whose expression in mammalian gonads, as will be discussed later, shows sexual specificity after a certain stage. In reptiles, however, it is not differentially expressed in response to temperature variation during the TSP, so that its role in reptile sex determination is unclear. DAX1 gene is also expressed in crocodilians with temperature-dependent sex determination, such as Alligator mississippiensis. Whether this gene could indeed be a target for androgen or estrogen-related actions following the TSP remains unknown (Schartl, 2004; Maldonado et al., 2002).

DMRT1 was first considered as a gene involved in sex determination in Drosophila melanogaster, because of having a domain compatible to the sex determinant gene DSX. Subsequent research, however, has proven the gene's expression in several other species as well, including birds, fish and reptiles. In alligators, such as Alligator mississippiensis, the gene is expressed exclusively in the gonads of males. Moreover, its expression appears to precede that of SOX9, another testis-specific gene conserved in a vast number of species, ranging from reptiles to mammals. The latter gene is originally expressed in the bipotential gonad of reptile embryos, but following the TSP, it remains active only in males, making it a candidate gene for sex steroid-induced regulation (Schartl, 2004; Maldonado et al., 2002).

In alligators, SOX9 is also related to increased MIS (Müllerian Inhibiting Substance) levels, but, contrary to mammals, MIS induction chronologically 
precedes that of SOX9 (Schartl, 2004; Maldonado et al., 2002). In the case of lizards, an attempt has also been made to examine sexual dimorphism in the brain. The first results from these experiments show distinct differences in estrogen receptor expression and progesterone concentrations in specific areas of the central nervous system, a finding that may imply that aromatase regulation is only the first step in a sequence of several more complex sex-specific/dimorphic genetic phenomena that still remain to be examined (Wennstrom et al., 2003). Finally, it has recently been suggested that aromatase may also be regulated by secondary parameters, other than temperature. This has been described for instance, in the case of prostaglandin E2, which appears to be associated with increased aromatase action (Simpson et al., 2001). Immunological reactions and cytokine levels may also be important (Purohit et al., 2003).

\section{b. Amphibians}

The thermosensitivity of the gonads has been demonstrated not only in reptiles, but also in several fish and some amphibians. These species tend to combine a genotypic sex determination mechanism -either male heterogamety, female heterogamety or polygenic- with aromatase activity. This may result in sex reversal, where the effects of temperature may go against the genotypic directions, allowing the existence of animals in genotypic and phenotypic sex discordance (Sarre et al. 2004). The exact mechanism by which temperature regulates sex determination in amphibians is yet to be deciphered, but it doesn't seem to be the same as reptiles. Of the various genes so far associated with sex determination in other species, amphibians appear to express DMRT1. However, it is yet to be determined whether this is a downstream product in the sex differentiation cascade or a factor with a more central role in sex determination (Schartl, 2004; Aoyama et al., 2003; Shibata et al., 2002).

\section{c. Fish}


There are numerous species of fish in the animal kingdom. Among such a variety of living organisms, research has been focused on relatively few, specific model organisms, each of which has been considered representative of the reproductive physiology of several other closely related species. Variable patterns of sex determination apply to fish: 1 . The presence of true hermaphrodites, an approach usually associated with lower evolutionary levels such as model of invertebratesnematodes. 2. Temperature-dependent sex determination, with a process similar to the one of the reptiles. 3. Presence of sex chromosomes (Manolakou et al., 2006). Contrary to mammals, the sex determining genes are yet to be described in fish, although some candidates have been proposed. It might also be possible that, instead of a common, uniform gene pattern for all fish, different genes play the major sex determinant roles in different species. It might also be possible to assume a number of competing genes in every species, with environmental and/or hormonal parameters regulating their relative priority in sex determination. For instance, the platyfish (Xiphophorus maculatus)'s genome may contain any of three sex chromosomes, namely $X, Y$ and $W ; W X, W Y$ and $X X$ develop as females, while $X Y$ and $Y Y$ become males. No specific sex-determining gene has been described so far. However, the $\mathrm{W}$ chromosome is considered a major candidate for this function, since its presence coincides with female phenotype regardless of the type of the second sex chromosome. Although classical hormonal regulators of sex differentiation such as MIS have not yet been identified in fish (Hofsten et al. 2005), SOX family members such as SOX9, as well as $D M R T 1$ are found in this and other kinds of fish. DMRT1 has been shown to be particularly important for sex determination in the teleost medaka, Oryzias latipes. The sex determining system of the medaka follows the XX/XY principle known for mammalian reproduction: males are $X Y$ heterogametic and females are $X X$ homogametic. Although some similarities with genes of the mammalian sex chromosomes may exist, the major sex determinant of mammals, $S R Y$, is missing. Indeed, in the $\mathrm{Y}$ chromosome of the fish a new gene has been detected, bearing six exons and a DM domain (Matsuda et al. 2005). The latter is a major characteristic of genes involved in sex determination in invertebrates, such as 
doublesex and mab3 in Drosophila melanogaster and C.elegans, respectively. This new gene was named DMY (DM domain of the $\mathrm{Y}$ chromosome) and it is homologous to $D M R T 1$ gene, which is conserved in various species. It appears that in the male, DMY and DMRT1 operate in procession as strong determinants of gonadal development. In the female, the role of aromatase is once again central, although its induction, in this case, may be a genetic rather than temperature-related event. Other genes' expression has also been detected exclusively in females, such as FIGa (factor in the germ line a) (Matsuda et al. 2005). Finally, sex determination in the zebra fish is considered to be a genetic phenomenon, but the details of the process are still under examination. Of particular interest are recent data, proving the expression of two sex-related genes in the zebra fish. These are a) VASA, a gene family expressed exclusively in the gonads of several species, including D.melanogaster, mice and fish and b) FTZF1 (fushi tarazu factor 1), a gene originally described in Drosophila and known to encode the steroidogenic factor 1 (SF1) in mammals, thus regulating sex steroid production (Krovel et al. 2004, Fujiwara et al. 1994). Interestingly, the rainbow trout is an interesting model for the study of Fox/2. Firstly, the trout genome went through a tetraploid phase, then a diploid phase in evolution. Secondly, sexual differentiation, even genetically controlled by an XY/XX mechanism, can be modified by environmental factors such as hormones, leading to the development of fertile neo-XX males or neo-XY females (Baron et al., 2005). In trout there are two FOXL2 genetically independent paralogue genes: FOXL2a and FOXL2b. FOXL2a expression is similar to that observed for the mammalian FOXL2 gene. FOXL2b, being specific of somatic cells of the ovary, is expressed later than FOXL2a. As well, the expression of FOXL2 in the ovarian somatic compartment is also found in the ovaries of estrogen-treated neo-XY females. Conversely, FOXL2 expression is not found in androgen-treated neo- $X X$ males. Accordingly, the expression of FOXL2 sharply decreases in XX females treated with aromatase inhibitors (Baron et al., 2004).

\section{d. Birds}


In birds females are the heterogametic (ZW) and males the homogametic sex (ZZ). However, we have yet to decipher which of the two ( $Z$ or $W$ ) is responsible for the choice between males and females. Sex may depend on $Z$ chromosome dosage, according to the example of D.melanogaster and C.elegans. One candidate gene for this theory is DMRT1, which is located on the $\mathrm{Z}$ chromosome. This gene escapes dosage compensation and is expressed specifically in the gonads, and is thus capable of linking the number of $Z$ chromosomes with gonadal differentiation (Ellegren et al. 2001, Smith et al. 2004). On the other hand, sex may be determined by the feminizing presence of the $W$ chromosome, following the example of $Y$ in eutherian mammals. The FET1 gene, which is located on $W$, does not have a $\mathrm{Z}$ homologue and is expressed almost exclusively in the female urogenital system. As well, products of the ASW gene, also known as $W P K C l$, and its $\mathrm{Z}$ homologue $\mathrm{ZPKCl}$, are capable of dimerisation, with a $\mathrm{ZPKCl}$ homodimer acting as a testis factor and a WPKCl/ZPKCl heterodimer preventing this effect (Pace et al. 2003, Smith et al. 2004). However, studies of ZW aneuploidy have shown that $Z Z Z$ animals develop testes but are infertile, $Z W W$ animals die early in embryonic development, but ZZW combinations manifest as intersexual: the animals appear female on hatching, but slowly turn into males at sexual maturity. It is still possible, thus, that combinations of the above mechanisms are functional (Ellegren et al., 2001; Clinton et al., 1999).

\subsection{Mechanisms of sex determination in mammals}

In mammals, sex determination is genetically controlled by the presence or absence of the $Y$ chromosome, and in particular, of a transcriptional factor SRY (sex determining region on the $Y$ chromosome). From marsupial with the smallest $Y$ chromosome to eutherian mammals, undifferentiated $X Y$ gonads usually turn into testes (Manolakou et al., 2006: Waters et al., 2007). In the conventional view of mammalian sex determination the basic pathway of organ development is ovarian, and the testis-determining gene operates by diverting this program 
toward testis development through simultaneously influencing the fate of the key supporting cell lineage and initiating a male-specific morphogenetic program in chromosomal males. In 1947, Alfred Jost demonstrated that if $X X$ and $X Y$ rabbit fetuses were castrated in utero before sexual differentiation, they would develop female ducts and external genitalia (Jost, 1947). Therefore, development of ovary represents the "default" state and is independent of gonadal hormones. Sex differentiation, defined as the development of any male- or female-specific physical or behavioural characteristic, is the series of molecular events that direct the undifferentiated bipotential gonad to become either a testis or an ovary (Fig. 1). Sexual differentiation supplies organisms with the anatomy and physiology necessary for sexual reproduction. As far as the genetics of sexual development is concerned, arguably the most significant events unfold within the fetal gonads. Although in mammals the sexual fate of the organism is cast at fertilization, this fate is revealed only during fetal development, when the gonads begin to differentiate as ovaries or testes after a considerable period of sexual ambiguity. All secondary sexual dimorphisms are thought to follow the differentiation of the gonads and their acquisition of endocrine function (Wilhelm et al., 2007). My study is focused on sexual differentiation in the mouse.

\subsubsection{Morphological Gonadal Organogenesis}

In all mammalian species, the embryonic gonad is made up of a mixed population of somatic cells and germ cells. This tissue is remarkable in that all of its cells are believed to be bipotential, and can differentiate into ovarian or testicular lineages (Eicher et al., 1986; Albrecht et al., 2001). At first, scientists had various ideas regarding the origin of somatic cell types forming the mammalian gonads; Byskov et al. (1977) proposed that, although the mesonephric-derived cells were crucial for gonadal differentiation, a minor role of coelomic epithelial cells cannot be excluded. Wartenberg (1978) suggested a dual origin of the somatic elements of the gonads; i.e., one cell type derives from the mesonephros and the other proliferates from the coelomic epithelium. Some claimed that the only significant 
somatic cell type of the developing gonads is that derived from the mesonephros (Upadhyay et al., 1979; Zamboni et al., 1981). To date we know that the mammalian gonad forms on the surface of the mesonephros within the urogenital ridge. This occurs through proliferation of the mesothelium (coelomic epithelium) in a restricted region on the medio-lateral side of the mesonephros, and through the allocation of cells from the mesonephros. At the same time, germ cells are completing their migration from the base of the allantois along the gut tube, and through the mesonephros to the site where the gonad is forming (Kim \& Capel, 2006). Different species have been studied with respect to early gonadal mesonephric interaction including mouse, rabbit, sheep, human; most reports are based on histological and ultrastructural studies of early stages of gonadal development (Byskov, 1986). The mouse is, by far, the most studied and the bestcharacterized model of mammalian sex determination. It is assumed that events in the human embryo follow the same basic pattern, even if there are differences in timing and anatomy. However, there are variations in mammalian sexual differentiation. After gastrulation, organogenesis in the mouse embryo starts approximately 8 days post coitum (dpc). The gonad, adrenal gland, kidney, and reproductive tract can be traced to a derivative of the intermediate mesoderm that forms at $9.5 \mathrm{dpc}$. The indifferent gonads arise as paired structures within the intermediate mesoderm, which lies on either side of the embryo filling much of the coelomic cavity between the limb buds during the first half of development. Within this region, three segments comprising the urogenital ridge are distinguished from anterior to posterior: 1) the pronephros, which includes the adrenal primordium near its caudal end; 2) the mesonephros, the central region from which the gonad arises; and 3) the metanephros, the most posterior region from which the kidney forms. The gonads emerge on the ventromedial surface of the mesonephros at $10.5 \mathrm{dpc}$. Cells that delaminate from the coelomic epithelium seem to provide one source of cells for the growing genital ridges, while recruitment of underlying cells from the mesonephros to the epithelial population also augments the cell population in the gonadal primordium in males (Wilhelm et al., 2007). From the earliest stages of gonad development, the mesonephric tubules form continuous 
bridges to the epithelial cells of the gonad in male and female genital ridges (Karl et al., 1995). No function for these tubule connections has yet been defined.

The early mammalian gonad is an undifferentiated primordium composed of bipotential precursor cells that can follow one of two possible fates. Precursors for supporting cells and steroid-secreting cells are believed to be present in the early gonad (Merchant-Larios et al., 1993). Supporting cell precursors continue to delaminate from the coelomic epithelium until $11.5 \mathrm{dpc}$ (Karl \& Capel, 1998). Supporting cell precursors can develop into either testis-specific Sertoli cells or ovary-specific follicle (granulosa) cells. In mosaic gonads, consisting of a mixture of $X X$ and $X Y$ cells, small numbers of $X X$ cells develop as Sertoli cells (Palmer \& Burgoyne, 1991a), and $X Y$ cells develop as granulosa cells (Burgoyne et al., 1988; Palmer \& Burgoyne, 1991). In addition, transgenic mice that express a reporter protein (green fluorescent protein, GFP) under the control of the Sry promoter express it not only in Sertoli cells in XY gonads, but also in granulosa cells in an XX gonad (Albrecht et al., 2001). As well, the steroid-secreting Leydig cells in the testis and theca cells in the ovary, which engage in many common steroid pathways, probably derive from a single precursor. In contrast, other characteristic cell types in the gonad are recruited differently in the testis versus the ovary (Wilhelm et al., 2007). Sex-specific differences are apparent at about $12.5 \mathrm{dpc}$ when the male gonad takes on a striped appearance, probably due to cells of the supporting cell lineage differentiating into Sertoli cells and aligning into testis cords, the presumptive seminiferous tubules. The ovary forms 2 or 3 days later in female embryos, behaving as a default pathway, initiated in the absence of specification of the male pathway. The testis comprises three main cell types: Sertoli cells, Leydig cells, and germ cells. Sertoli cells and germ cells form seminiferous tubules where spermatogenesis occurs. The Leydig cells populate the interstitial compartment and produce testosterone. The ovary also comprises three main cell types: granulosa cells, theca cells, and oocytes. The oocytes are surrounded by granulosa and theca cells forming follicles that grow and develop at puberty. The Sertoli cells and granulosa cells surround the germ cells in their respective organs. However, germ cells are not required for testis determination 
because mice homozygous for the Kit mutation lack germ cells yet form somatically normal testes (McLaren, 1995).

\subsubsection{Germ Cells}

\section{a. Origin and migration}

The primordial germ cells (PGCs) do not arise within the genital ridge or the mesonephros, but they originate from the base of the allantois at the posterior end of the primitive streak (Lawson \& Hage, 1994). At 6-6.5 dpc, the precursors of the PGCs can be found in the epiblast close to the extraembryonic ectoderm, but they are evidently not yet restricted to a germ cell fate because they can also form extraembryonic mesoderm. By $7 \mathrm{dpc}$, these cells are in the region of the forming hindgut. As development proceeds, the hindgut invaginates and the germ cells are swept into the embryo. Although germ cells have the capacity for active migration, this early stage is likely to be a passive process as they are not motile. By $9.5 \mathrm{dpc}$, PGCs commence leaving the hindgut and enter the forming urogenital ridges, which are in close proximity at this time. As development proceeds, the hindgut descends into the coelomic cavity and PGCs arriving later must migrate through the dorsal mesentery before entering the developing gonads. Survival of the PGCs during migration is dependent on an interaction between the tyrosine kinase receptor C-KIT, which is present on the surface of PGCs, and its ligand, stem cell factor (SCF), which is produced by the surrounding tissues (Bendel-Stenzel et al., 1998). During migration the PGCs also undergo several rounds of cell division to achieve a population of about 3,000 cells by $11.5 \mathrm{dpc}$, when almost all the PGCs have arrived at their destination. Once inside the genital ridge, the germ cells lose their motility and begin to aggregate with one another. They continue to proliferate within the indifferent gonad and maintain their bipotentiality until $13 \mathrm{dpc}$, whereupon germ cells within the male gonad become enclosed within the forming testis cords and enter mitotic arrest as T1 prospermatogonia. In the female, 
proliferation continues for a short while longer before the germ cells enter meiosis at $13.5 \mathrm{dpc}$.

\section{b. Differentiation of PGCs and somatic cells}

Primordial germ cells have the potential to develop either as meiotic oocytes, progressing through the first meiotic prophase and arresting in diplotene just after birth, or as prospermatogonia, mitotically arrested in G1/G0 until a few days after birth, when they resume proliferation (Hilscher et al., 1974; McLaren et al., 1984). This developmental switch, which has occurred by $13.5 \mathrm{dpc}$, is dependent on the sex of the somatic cells in the gonad, rather than the chromosomal sex of the PGCs: XY PGCs can develop as oocytes in female embryos, and XX PGCs can develop as prospermatogonia in male embryos (Ford et al., 1975; Palmer \& Burgoyne, 1991a). When germ cells migrate into ectopic sites such as the adrenal gland, they will develop as oocytes even in male embryos, entering meiosis with apparently normal timing (Zamboni \& Upadhyay, 1983).

Germ cells seem to play a more active role in ovary development than in testis development. In the absence of germ cells, supporting cells in the ovary differentiate into prefollicle cells that aggregate into mesenchymal condensations, but these eventually degenerate, leaving only stromal tissues. The involvement of germ cells in the differentiation and maintenance of the male supporting cell lineage is less obvious, as germ cells are required neither for the differentiation of Sertoli cells nor for the assembly of testis cords (McLaren, 1991).

\section{c. Meiosis}

It has been proposed that PGCs enter meiosis driven by an intrinsic clock and that as an yet uncharacterized signal produced by the somatic cells in a male genital ridge inhibits PGCs from entering meiosis, arresting them in $\mathrm{G} 1 / \mathrm{G} 0$, and directing them towards spermatogenesis (Dolci \& De Felici, 1990; McLaren \& Southee, 1997). PGCs in male genital ridges can be rescued from this signal if they are 
removed from the genital ridges at $11.5 \mathrm{dpc}$ and will develop as oocytes in lung aggregates. However, by $12.5 \mathrm{dpc}$, PGCs isolated from male genital ridges are committed to spermatogenesis (Adams \& McLaren, 2002; McLaren \& Southee, 1997). After birth the normal $X Y$ male germ cell starts its life cycle with a series of mitotic divisions. At puberty a certain fraction of the germ cells (spermatogonia) begin the spermatogenic cycle by entering the first meiotic prophase, thus becoming spermatocytes. After the meiotic divisions the spermatids differentiate into spermatozoa with either a $Y$ or an $X$ chromosome.

Entry into meiosis in the female embryo occurs in an anterior to posterior wave, a situation that possibly might not occur under the action of an intrinsic clock (Zamboni \& Upadhyay, 1983). Cocultures of fetal testes and ovaries showed that non-meiotic germ cells within the testes were induced to enter meiosis by close apposition with ovarian tissue in a dosage dependent manner (Byskov, 1978; Byskov et al., 1993; Byskov \& Saxen, 1976). These observations suggest that in the embryonic testes either this meiosis-inducing factor does not exist or a meiosis-inhibiting factor is produced. Recently it has been revealed that the retinoic acid produced within the mesonephros induces the entry into meiosis (Bowles et al., 2006; Koubova et al., 2006). PGCs in male gonadal explant cultures treated with exogenous retinoic acid start to express meiosis markers such as Stra8, Scp3, and Dmc1, whereas PGCs in female explants cultures treated with inhibitors of retinoic acid signalling do not enter meiosis but instead continue to express the pluripotency marker Oct4. Male germ cells are protected from the effects of retinoic acid by their location within the testis cords. Sertoli cells, which surround PGCs in the testis cords, express CYP26B1, an enzyme that catabolyzes retinoic acid and is therefore the male-specific meiosis-inhibiting factor (Bowles et al., 2006).

\subsubsection{Ductal System: Development and Differentiation}

In mammals, the primordia of both male and female duct systems are initially present in the mesonephroi. The Wolffian (or mesonephric) ducts are the 
progenitors of the male duct system and first appear in the mouse in short, transient segments within the pronephros, then as a stable continuous tube along the length of the urogenital ridge, adjoining the cloaca at its caudal end (Capel, 2000). The precursor of the female ductal system, the Müllerian (or paramesonephric) duct, forms by invagination of a tube from the surface epithelium of the mesonephros. This tube extends parallel to the Wolffian duct in both male and female embryos. Later on in development, one of the two duct systems will degenerate in mammals, depending on the differentiation of a testis or ovary. In addition to the duct formation, the mesonephric tubules form shortly after the Wolffian duct appearance and extend through the mesenchyme of the mesonephros toward the coelomic surface. The mesonephric tubules may play a role in the development of both the adrenal gland and the gonad either through signalling to the surrounding regions or by the direct contribution of cells to the forming organs (Wilhelm et al., 2007).

\subsubsection{Testicular differentiation}

Testis differentiation, defined as the proliferation and differentiation of supporting cells and their organization into testis cords, is induced by the expression of a male specific gene named Sry (Sex determining Region on $Y$ chromosome) in a subset of somatic cells that are due to differentiate into Sertoli cells. Testicular differentiation is characterized by three consecutive events: 1) Sertoli cell differentiation, 2) Testis cords formation, 3) Differentiation of Leydig cells in the interstitium. In parallel to the differentiation of Sertoli cells, the gonad increases remarkably in size due to the increased proliferation and migration of cells from adjacent mesonephros to the developing gonad. All of the experimental evidence suggests that these two processes are closely interwoven. For example, both proliferation (Schmahl et al., 2003) and migration of cells to trigger testis cord formation appear to be closely integrated with Sertoli cell differentiation (Tilmann et al. 1999). 


\section{a. Cell proliferation}

Early studies in several mammalian species suggested that the choice between testis and ovarian patterns in the gonad is potentially controlled by cell proliferation and gonad growth. At equivalent gestational ages, male embryos are more developed than females on average (Scott and Holson, 1977; Pedersen, 1980; Seller \& Perkins-Cole, 1987). The observation that the early male gonad is larger than the female gonad in many vertebrates supports the view that the differential growth rate between the sexes somehow determines the sex of the gonad, such that gonads with more rapid growth rates become testes, while gonads which failed to reach a certain size by a given stage develop into ovaries (Mittwoch, 1969, 1989; Mittwoch and Buehr, 1973; Hunt and Mittwoch, 1987). However, many studies comparing gonad size between the sexes did not take it into account. Additionally, the more rapid growth rate of male embryos is not an absolute distinction: some male embryos are smaller and develop more slowly than their female littermates, suggesting that growth rate and/or developmental acceleration are not the primary determinants of the sex of the embryo. After discovery of Sry as the testis determining gene, it was realized that expression of Sry initiates a dramatic increase in somatic cell proliferation in $X Y$ gonads at 11.25 dpc. In contrast, proliferation in the female gonad changes very little at this time (Schmal et al., 2000). Using the expression of sex-specific genes and the formation of testis morphology as markers of testis determination, it was found that proliferation within a specific 8 hour time window, coinciding with the initiation of Sry expression, is critical for the establishment of the male pathway and the formation of the testis. These studies suggested that proliferation is involved not only in the elaboration of organ pattern, but also in the choice between male and female patterns in the bipotential gonad. However, Inhibition of proliferation before or after this critical period led to smaller gonads, but did not block testis formation (Schmal \& Caple, 2003).

\section{b. Cell migration}


During gonadal differentiation, mesonephric cells make a substantial contribution to the structure of the ovary or testis. The study of early testis differentiation in the rabbit (Wartenberg et al., 1991) illustrated that cells migrate from both the mesonephros and the coelomic epithelium to the developing testis. The migration of mesonephric cells takes place in $X Y$ but not $X X$ gonads from 11.5 to $16.5 \mathrm{dpc}$ in mice and contributes to the interstitial cell population; the myoid, the endothelial, and some cells closely associated with endothelial cells, but not in the Sertoli cells or the germ cells (Martineau et al., 1997; Buehr et al., 1993, Cotinot et al., 2002). This migration is necessary for seminiferous cord organization in the testis, as it is consistently associated with Sry's presence and with testis cord formation (Caple et al., 1999; Buehr et al., 1993). The signal that triggers this migration operates over long distances, behaving as a chemoattractant, and fibroblast growth factor 9 (FGF9) seems to be the main factor responsible for this chemoattraction (Colvin et al., 2001). Indeed, when the migration is blocked, no cord formation occurs in the $X Y$ gonad. By contrast, when the migration is induced in $X X$ gonads, they develop cord structures and acquire male-specific gene expression patterns (Tilmann et al., 1999). Mesonephric cell migration is most likely induced by secreted factors expressed under the direct or indirect control of Sry. Several factors have been implicated such as neurotropin-3 (NT-3), hepatocyte growth factor (HGF) and platelet-derived growth factor (PDGF) (Smith et al., 2005; Wilhelm et al., 2007). However, all data obtained to date are in vitro or in ex vivo gonad cultures; it is still not known whether these factors play a role in vivo. Moreover, it is not clear whether a single factor induces the migration of one or more precursor cell type or several factors are each responsible for the migration of different cell precursors. It seems as if the first mechanism is working, since interference with any of the pathways studied so far resulted in the blockage of migration of all cells, not just a subset of cells (Wilhelm et al., 2007).

\section{c. Sertoli cell differentiation}


In the adult testis Sertoli cells are somatic cells that associate with germ cells and nurture their development into sperm; serving as a specific compartment for spermatogenesis and antimullerian hormone [Mullerian Inhibiting Substance (MIS)] secretion. Additional functions in the adult testis include synthesis of androgen-binding protein, secretion of fluid, phagocytosis of degenerating germ cells, and secretion of inhibin, a peptide with a negative-feedback effect on folliclestimulating hormone (FSH). Sertoli cells are named after the man who described their supporting and nutritive role for the germ cells in the human testis. It was not clear whether the Sertoli cell population is uniform or composed of cell types of different origin. A dual origin of the Sertoli cells was proposed, studying the fetal testis of the human and rabbit. On the other hand, a uniform origin of the Sertoli cells from the mesonephros was suggested by studies of the fetal mouse and sheep (Byskov, 1986). Later on, it was illustrated that they do not originate from mesonephros and the lineage that gives rise to Sertoli cells originates from the coelomic epithelium (CE) of the genital ridge, but these cells are also able to give rise to an interstitial cell type (Karl and Capel, 1998). After the coelomic epithelial cells migrate into the gonad, there is first a decision to become interstitial or supporting cells and then the transient expression of Sry in each pre-Sertoli cell, not in coelomic epithelial cells, determines its fate as a Sertoli cell by up-regulating Sox9 (Sekido et al., 2004) as it initiates differentiation. Sertoli cells are believed to act as the organizing center of the male gonad and orchestrate the differentiation of all other cell types. They are the first cell type known to differentiate within the gonad from bipotential precursors of the supporting cell lineage and are therefore the first indicator that the gonad has passed from the indifferent stage into testis development. The differentiation from pre-Sertoli cells into Sertoli cells is marked by the polarization of the cells when they form epithelial aggregates that assemble into testis cords. At the same time there is a change in the expression of certain extracellular matrix proteins; desmin is downregulated, whereas cytokeratins are upregulated (Wilhelm et al., 2007). Sertoli cells only proliferate during fetal and neonatal development. During fetal and neonatal development Sertoli cells undergo characteristic structural changes that lead to the specific structure of the 
adult Sertoli cell. During early stages of differentiation the shape of the Sertoli cells is roughly columnar with thick cytoplasmic extensions surrounding the prespermatogonia. Gradually they become more irregular in shape. They form long slender cytoplasmic extensions from their lateral and apical surfaces that reach into each other and surround the germ cells. In the fetal testis they are looser and tight junctional characteristics of the Sertoli cell membranes, which in the adult testis form the blood-testis barrier, are not present. However, incomplete tight junctions are observed between the plasma membranes of fetal Sertoli cells in the mouse, rat, and human. With advanced stages of differentiation, the Sertoli cell population seems to achieve a uniform appearance. Although the adult Sertoli cells apparently do not synthesize steroids de novo, they possess the essential enzymes for converting progesterone to testosterone and in particular to estradiol. The ability to synthesize these enzymes has probably been preserved from fetal life. Generally the newly enclosed Sertoli cells resemble fetal undifferentiated cells with lack of cell organelles but possessing all organelles of a protein-synthesizing cell (Byskov, 1986). Sertoli cells are the only cell type within the developing testis that requires the cell-autonomous expression of Sry. However, Sry is not necessary for differentiation of all Sertoli cells. In addition, the number of Sertoli cells must reach a certain threshold to guarantee testis development (Palmer \& Burgoyne, 1991a).

\section{d. Peritubular myoid cells}

The peritubular myoid (PM) cell is one of the three cell types that migrate from the mesonephros into the male gonad. PM cells form a single layer of flattened cells which surround the Sertoli cells and circumscribe the testis cords. They are known to have two main functions: 1) contribute structurally to the formation of the testis cords in conjunction with Sertoli cells, 2) promote the movement of mature sperm through the seminiferous tubules of the adult testis for export to the seminal vesicles. PM cells represent the only cell type in the testis so far for which no counterpart can be identified in the ovary (Wilhelm et al., 2007). 


\section{e. Testis cord formation}

Testis cords are the first morphological sign by which a differentiating gonad can be recognized as a testis. Initially the testicular cord diameter varies, but soon the cords become regular with a constant diameter. The somatic cells that become part of the cords are the presumptive Sertoli cells, and the germ cells are the future spermatogonia (Byskov, 1986). The gonad becomes separated by septa perpendicular to its long exis. The packing of Sertoli cells and germ cells is very tight, with extremely narrow intercellular spaces. In contrast, the intercellular spaces in the extracordal compartment are clearly visible. Throughout differentiation the plates or cords remain in connection with the basal part of the mesonephric cell mass. This cell mass gradually transforms into a network of cords, the rete testis (Byskov, 1986). Differentiation of the testicular cords occurs rapidly. Toward the periphery of the cords the Sertoli cells become flattened and a basal lamina begins to form. Blebs of cytoplasmic extensions from the Sertoli cells and sometimes from germ cells reach through the basal lamina (Magre \& Jost, 1980). These blebs are probably pinched off when the final enclosure of the basal lamina takes place (Byskov et al., 1983). Whereas the connections between the testicular cords and the rete testis remain intact, connections between testicular cords and the coelomic epithelium are only seen during the beginning of testicular differentiation (Merchant, 1975; Paranko et al., 1983; Torrey, 1945). The coelomic epithelium transforms into an epithelium with an intact basal lamina, and simultaneously the testicular cords retract from the testicular surface. This process leaves an area of loose mesenchymal tissue beneath the coelomic epithelium that develops into the tunica albuginea. The selection of the Sertoli cells may occur randomly among the mass of somatic cells, whereas practically all germ cells are confined to the cords. However, experiments in which the germ cells were virtually eliminated by irradiation (Mintz, 1959) or by treatment with busulfan (Merchant, 1975) indicated that testicular cord formation took place, regardless of the number of germ cells left. Therefore germ cells are not necessary for testicular cord 
formation. The developing testis becomes well vascularized when the testicular cords form. Capillaries grow between the arches of the testicular cords. In particular, the blood vessels in the developing tunica albuginea become clearly visible soon after sex differentiation.

\section{f. Leydig cell differentiation}

Steroidogenic Leydig cells differentiate within the second compartment of the testis, the interstitium. They were first described by Franz Leydig in 1850.50 years later Bouin and Ancel demonstrated that these cells secrete a hormone that plays a role in establishing and maintaining the secondary male sex characteristics (Bouin \& Ancel, 1903). Leydig cells often lie in clusters close to blood vessels, in line with their steroidogenic role. In mammals there are two types of Leydig cells. The fetal Leydig cells originate, at least in part, in the mesonephros, and are responsible for the production of androgen for the fetal masculinization; these cells probably degenerate postnatally (Hardy et al, 1993). The adult Leydig cells, which differentiate after birth, appear to be unrelated to their fetal counterparts. They arise from undifferentiated precursor cells that are part of the mesenchymal cells of the interstitium (Hardy et al, 1993: Wilhelm et al., 2007). The Leydig cells are in fact the most potent cells in androgen synthesis. They differentiate in the interstitium shortly after the testicular cords have formed. During testicular differentiation the Leydig cells gain the characteristics of typical steroid-producing cells. The amount of endoplasmic reticulum increases and changes gradually from a rough to a tubular agranular form that occupies most of the cytoplasm. The mitochondria increase in number and become spherical with tubular cristae. The morphological differentiation of the fetal Leydig cells is closely correlated with steroidogenic activity. Differentiation of the Leydig cells appears to depend on the formation of the testicular cords. In cultures of minced testicular tissue, testosterone production is decreased and the morphological differentiation of typical Leydig cells does not happen, whereas in cultures of intact testes with wellstructured testicular cords, the Leydig cells differentiate well and testosterone 
production is high. The development or maintenance of the appropriate enzymes necessary for synthesis of testosterone from progesterone seems to depend on interaction between cells of the testis cords and interstitium (Byskov, 1986). Progesterone may influence the differentiation of the testicular cords themselves and/or the differentiation of the steroid metabolic system of the Leydig cells. The number of Leydig cells that differentiate during early life changes with the secretion of testosterone by the testis. They are numerous and fully differentiated when testosterone reaches peak levels in the fetus, then they dedifferentiate, and testosterone production decreases (Byskov, 1986). Mitotic figures in Leydig cells are almost exclusively present during early stages of testicular development (Gondos, 1977). The fluctuation in the Leydig cell number seems to result from differentiation and/or regression of cells in relation to a fixed pool of Leydig cell precursors (Gondos, 1977; Wartenberg, 1981) since mitosis becomes rare or absent in later stages of development. Later on in the fetal development, the maintenance of Leydig cell function and steroid secretion is regulated by gonadotropins.

\section{g. Vascular and other interstitial cells}

Although Leydig cells are often considered as the major component of the testicular interstitium, there are several other interstitial cell types including endothelial cells, fibroblasts, and blood-derived cells such as macrophages, lymphocytes, plasma cells, monocytes, and mast cells. Endothelial cells together with PM and Leydig cells represent the third cell type that migrate into the testis from the mesonephros (Martineau et al., 1997). They form the male-specific vasculature with the prominent coelomic vessel on the surface of the gonad and side branches in between the testis cords. The formation of the vasculature and the testis cords are intimately interwoven (Wilhelm et al., 2007).

\subsubsection{Ovarian differentiation}


The ovary has two main functions: the production of steroid hormones and the generation of mature oocytes that are capable of being fertilized and developing into embryos. The functional unit of the ovary is the ovarian follicle which commences differentiation only after birth. The oocytes are surrounded by granulosa and thecal cells and mature in the ovarian follicles (Wilhelm et al., 2007). In the mouse, the fetal gonad appears inert for several days in females. However, female-specific gene expression commences as early as $11.5 \mathrm{dpc}$ (Bowles et al., 2000; Jorgensen \& Gao, 2005; Nef et al., 2005; Yao et al., 2004). Furthermore, there is a phase starting around 13.5 to $15.5 \mathrm{dpc}$, in which the poorly differentiated structure undergoes remodelling. The presumptive oocytes develop as interconnected cysts that are linked by cytoplasmic bridges (Pepling \& Spradling, 1998). There is also a high degree of vascularization, with a dense network of small vessels (Bullejos et al., 2002) which demarcate strings of germ cells, also known as ovigerous cords (Konishi et al., 1986, Odor \& Blandau, 1969). The function of this vascularization is not known. However, the vasculature in males and females might serve the same function, delivering exogenous growth factors to the somatic and/or germ cells. In most mammals the characteristic sign of a differentiating female gonad is the presence of germ cells entering meiotic prophase (Peter, 1970) which indicates differentiation of an ovary and not a testis. However, in many species such as sheep, pig, cow, and rabbit initiation of meiosis is not the first sign of ovarian differentiation, since meiosis is delayed during an early period of ovarian differentiation when the germ cells are enclosed in more or less well-defined germ cell cords. In the $12.5 \mathrm{dpc}$ mouse ovary, germ cells gather in clusters that are uniformly distributed throughout the ovarian tissue. $A$ thin rim resembling a tunica albuginea is present beneath the surface epithelium. During a limited period the ovarian surface epithelium may exert influences that are unfavourable for proliferation of germ cells and somatic cells. The ratio of germ cells to somatic cells is somewhat low in the basal part of the ovary, where mesonephric cells invade and where the first meiotic germ cells appear (Byskov, 1978). 


\section{Formation of primordial follicles}

The ovarian morphology undergoes a rapid reorganization within the first 3 days after birth. The intracellular bridges between oocytes within the ovigerous cords break down, and a somatic epithelial monolayer of flattened squamous pregranulosa cells closely surrounds the single oocytes. These definitive primordial follicles are separated from the somatic compartment with a basement membrane which surrounds the pregranulosa cells. At the same time, there is a reorganization of the ovary into morphological compartments, the cortex, where the primordial follicles reside, and the medulla. During the formation of the primordial follicles, high levels of oocyte death occur (Beaumont \& Mandl, 1963; Borum, 1961) due to a process known later as apoptosis, programmed cell death. It is likely that a combination of intercellular and intracellular signals triggers this massive cell death, which limits the number of primordial follicles. In contrast to the continuous proliferation of male germ cells, in females germ cells only proliferate during embryogenesis. It has been long thought that the female has a limited number of primordial follicles, which, alongside the rate of depletion of this pool, determines the reproductive life span of females. Recent reports of germ line stem cells (GCS) resident within the bone marrow challenged this dogma. This pool of stem cells may refill the ovary with new oocytes (Johnson et al., 2004; Johnson et al., 2005), an exciting possibility that is yet to be confirmed. During the formation of primary follicles the pregranulosa cells become cuboidal and commence the proliferation, the oocyte increases in size, produces the zona pellucida, an extracellular glycoprotein matrix deposit between the oocyte and the granulosa cells, and subsequently thecal cells surround the follicle. In fact, by the intragonadal factors that initiate the growth and extragonadal factors synchronizing granulosa and thecal cell function at later stages of folliculogenesis control these processes. On the other hand, other primordial follicles remain inactive until later so that there is a continuous production of preovulatory follicles, and follicles of each stage (primordial, primary, transitional, secondary, and antral) can be found at any given time. Moreover, not all follicles eventually ovulate 
successfully; many follicles are lost during folliculogenesis via atresia, a degenerative process involving loss of granulosa cells by apoptosis and subsequently the loss of the oocyte.

\subsection{Molecular genetics of gonadal differentiation (Fig.1.)}

\subsubsection{SRY: the master gene}

$S R Y$ is the master gene that orchestrates the cascade of testis determination in mammals. It was discovered 17 years ago by analysis of the small fragment of the $Y$ chromosome that had translocated to the $X$ chromosome in the $X X$ male (Sinclair et al., 1990). Characterization of three $X Y$ female patients with gonadal dysgenesis but no apparent cytogenetic abnormalities carrying frameshift mutation and single base substitutions in SRY provided evidence that $S R Y$ serves as the testis-determining factor (TDF) (Berta et al., 1990; Jager et al., 1991). However, the real proof was derived from mouse studies; Sry (the mouse ortholog) is deleted in a line of XY female mice (Gubbay et al., 1990), Sry is expressed in the somatic component of the genital ridge at exactly the predicted time for testis determination (Koopman et al., 1990) and transgenic XX mice carrying a genomic fragment containing the Sry gene develop as males (Koopman et al., 1991).

The gene was then mapped to the short arm of human $\mathrm{Y}$ chromosome, close to the pseudo-autosomal region, and consists of a single exon that encodes a 204amino-acid protein encompassing a conserved DNA binding domain of 79 amino acids, the HMG box (Cotinot et al., 2002) (Fig. 2). HMG (high mobility class of non-histone proteins) domain is the site of nearly all missense mutations causing XY gonadal dysgenesis (Hawkins, 1993; Poulat et al., 1994). Some of these mutations have been found to disrupt the interaction of SRY with DNA, affecting binding affinity or the angle of bend induced (Nasrin et al., 1991; Harley et al., 1992; Pontiggia et al., 1994; Poulat et al., 1994). Surprisingly, outside this domain, the SRY protein is poorly conserved among mammals, particularly in humans and 
mice. In human it remains possible that the HMG box might be the only functionally important domain required to bind and bend DNA and thereby allow SRY to act as an architectural factor, and also required for interacting with other proteins. The human SRY C-terminal domain has no obvious or conserved structure, except for the final seven amino acids, which interact in vitro with a PDZ domain protein (Poulat et al., 1997). The $\mathrm{N}$-terminal region of the protein also has no obvious structure, but phosphorylation of a sequence within this domain enhances DNA binding activity (Desclozeaux et al., 1998).

The mouse Sry gene codes for a protein containing an HMG box at $\mathrm{N}$-terminus, a bridge region, and a glutamine rich region which occupies over half of the protein at its C-terminus (Gubbay et al., 1992) (Fig. 2). The glutamine-rich domain is specific to mice and has an essential role in sex determination in vivo (Bowles et al., 1999); it has been suggested to be capable of acting as a transcriptional activation domain (Dubin and Ostrer, 1994). However, the lack of conservation of this domain in species other than mice raises doubts regarding its significance. SRY HMG domain binds to its target DNA in a sequence specific manner, preferentially to AACAAT, and causes a bend of about $90^{\circ}$ in its flanking chromatin in vitro (Nasrin et al., 1991; Ferrari et al., 1992; Harley et al., 1992; King and Weiss, 1993; Natesan and Gilman, 1993). The HMG domain also contains two distinct nuclear localization signals (NLS) flanking the domain, the N-terminal bipartite NLS and the monopartite C-terminal NLS, which modulate the nuclear localization (Südbeck and Scherer, 1997; Harley et al., 1996). The NH2-terminal NLS is recognized and bound by calmodulin (CaM), whereas the COOH-terminal acts via Importin- $\beta 1$ (Forwood et al., 2001). There are reports that SRY acts as a transcriptional activator, but also as a repressor. It is suggested that SRY forms transcriptional regulation complexes by interacting with other sex determining proteins or co-factors, encoded by autosomal and/or X-located genes, in mediating its biological function(s) (Eicher et al., 1996; Brennan and Capel, 2004). For both mouse and human SRY, a putative transactivation domain (TAD) has been described. The hinge or bridge region interacts with mouse SRY-interacting 
protein 1 (SIP-1/ NHERF2) and the KRAB-only protein (a novel protein containing only a Kruppel-associated box (KRAB) domain) (Poulat et al., 1997; Thevenet et al., 2005; Oh et al., 2005). This region is the only part outside the HMG box that shows reasonable homology between different species and human SRY interacts with SIP-1/ NHERF2 via its $\mathrm{COOH}$ terminus. Mutations in this region can lead to sex reversal in humans (Shahid et al., 2004; 2005). Interestingly, KRAB-only protein interacts with a corepressor complex leading to gene silencing, which would support the long-standing hypothesis that SRY acts as a repressor (McElreavey et al., 1993). Another protein, poly (ADP-ribose) polymerase-1 (PARP-1), is expressed in mouse fetal gonads at the time of sex determination and co-localized with SRY in the nuclei of pre-Sertoli cells. The interactive domains have been mapped to the HMG box of SRY and the zinc fingers of the PARP-1 protein, respectively. In the presence of its substrate, PARP-1 poly(ADPribosyl)ates minimizes severely the DNA-binding activities of SRY. PARP-1 represses Sry-mediated transactivation of a reporter gene in cultured cells. Hence, PARP-1 could modulate the regulatory function(s) of SRY on its target genes (Li et al., 2006). In addition to the direct transcriptional regulation, SRY has been implicated to play a role in splicing and thereby posttranscriptional control of gene expression, but the significance in vivo and genes that might be regulated are yet to be determined.

Sry is expressed within the pre-Sertoli cells; it was first demonstrated by analysis of chimeric mouse gonads made of aggregation of the $X Y$ and $X X$ embryos. Prior to the identification of Sry analysis of $X X / X Y$ chimeric testes indicated that Sertoli cells show a strong bias for the presence of a $Y$ chromosome, whereas all other lineages in the testis could be $X X$ or $X Y$ with equal probability (Burgoyne, 1988; Palmer \& Burgoyne, 1991a). In the mouse embryo, Sry exhibits a tightly controlled and limited spatiotemporal profile of expression in the pre-Sertoli cells of the $X Y$ gonad (Albrecht and Eicher, 2001; Sekido et al., 2004; Wilhelm et al., 2005; Taketo et al., 2005). Early studies revealed that Sry is first expressed around 10.5 
days post coitum ( $d p c)$, shortly after the emergence of the genital ridges, reaches peak levels of expression at $11.5 \mathrm{dpc}$, and is extinguished shortly after $12.5 \mathrm{dpc}$ in mouse (Koopman et al., 1990; Hacker et al., 1995; Jeske et al., 1995). Deeper analyses using in situ hybridization, transgenic reporter expression and immunofluorescence revealed that Sry mRNA and SRY protein display a dynamic expression pattern similar to a wave that emanates from the central longitudinal region of the genital ridges, then extends to rostral and caudal poles, and extinguishes in the order central-rostral-caudal (Albrecht and Eicher, 2001; Bullejos and Koopman, 2001; Sekido et al., 2004; Wilhelm et al., 2005). Mouse SRY protein is robustly expressed at $11.5 \mathrm{dpc}$ (Wilhelm et al., 2005; Taketo et al., 2005), despite the low level of mRNA expression. Individual cells are exposed to SRY activity for a period estimated at 8 hours or less (Sekido et al., 2004; Wilhelm et al., 2005). The correct timing of Sry expression is crucial for its function. Sry clearly throws a molecular switch to engage a male- specific cascade of molecular events, but continued expression of Sry is not required for these events to unfold.

\subsubsection{Other genes involved in gonadal sex differentiation}

\section{a. Bipotential stage}

Several genes are crucial for early gonadal development in both sexes, such as Lim1 (LIM homeobox gene 1), Lhx9 (LIM homeobox gene 9), Emx2 (emptyspiracles homeobox gene 2), Wt1 (Wilms' tumor suppressor 1), and Sf1 (steroidogenic factor 1). Mice homozygous for a null mutation of these genes lack genital ridges or have a blockage in genital ridge development (Shawlot \& Behringer, 1995; Birk et al., 2000; Miyamoto et al., 1997; Kreidberg et al., 1993; Luo et al., 1994; Ottolenghi et al., 2001). Kidneys and gonads are missing in the Lim1, Wt1, and Emx2 null mutants. Emx2 is essential for the formation of genital tracts. $L h \times 9$ can bind directly to the $S f 1$ promoter and has an additive effect to the WT1-induced activation in vitro. In mice lacking $L h \times 9$ function somatic cells of the genital ridge fail to proliferate and a discrete gonad fails to form. Unlike mice 
lacking other genes that mediate early stages of gonadogenesis, $L h \times 9$ mutants do not exhibit additional major developmental defects. Thus, LHX9 mutations may underlie certain forms of isolated gonadal agenesis in humans (Cotinot et al., 2002). Another gene, M33, homologous to Polycomb genes in Drosophila, has been shown to play a role in testis differentiation, probably by interfering with steps upstream of Sry. M33 null mice underwent a significant delay in gonadogenesis in both sexes. This retardation of gonad formation leads to the development of small ovaries in XX null mice and to partial or complete male to female sex reversal in $X Y$ null mice (Katoh-Fukui et al., 1998).

In addition to the mentioned genes, some of the genes involved in establishing sexual dimorphism are initially expressed in similar patterns in $X X$ and $X Y$ gonads, including Dax1 (dosage-sensitive sex reversal-congenital adrenal hypoplasia critical region on the $X$ chromosome protein 1), Sox9 (Sry-like HMG box 9), Fgf9 (fibroblast growth factor 9 ), and Wnt4 (wingless-related MMTV integration site 4), which is consistent with the idea that cells in the gonadal primordia are poised between two developmental pathways (Kim et al., 2006). On the other hand, genes such as $I r, I r r$, and $I g f 1 r$, together with $W t 1$ and $S f 1$ are thought to promote the expression of Sry in the XY gonads at the end of this developmental stage. Triple mutants of three insulin growth factor receptors (Ir, Igf1r, Irr), show male to female sex reversal; Sry levels are reduced and male development is not established. However, the primary role of insulin growth factor signalling in testis development is yet to be clarified (Nef et al., 2003). Special mention must be made of $W t I$ and $S f 1$ because these two genes arise at several levels in sexual differentiation. Their roles in gonadal formation have been mainly demonstrated by targeted disruption in the mouse (Cotinot et al., 2002).

\section{SF1}

SF1 is a nuclear receptor found predominantly in the endocrine tissues that control reproduction: the ventromedial hypothalamus, pituitary gonadotropes, 
adrenal gland and gonad (lkeda et al., 1996). Sf1 is expressed in the urogenital ridge at E9.5 (Ikeda et al., 1994; Ikeda et al., 2001). In the male gonad, SF1positive cells can be found in a population of coelomic epithelial cells that give rise to both Sertoli and interstitial cell precursors (Schmahl et al., 2000). In the Sertoli cell-lineage, one target of SF1 is the anti-Müllerian hormone (Amh/Mis) gene (Shen et al., 1994). Later in testis development, Sf1 expression intensity increases in the interstitial Leydig population where it regulates the expression of multiple steroidogenic enzyme genes necessary for testosterone production (lkeda et al., 1996; Morohashi et al., 1993). Sf1 is considered to be a master regulator of the reproductive system because it regulates the expression of a large array of genes required for gland development and hormone synthesis (Parker et al., 2002). SF1 protein acts by binding to a cognate DNA-response element (Rice et al., 1991) in the promoter regions of these genes. Unlike most nuclear receptors, SF1 binds DNA as a monomer (Wilson et al., 1993). SF1 interacts with a number of transcriptional co-activators (Val et al., 2003), and phosphatidyl inositol lipids may serve as ligands to regulate transcriptional activity (Krylova et al., 2005). In Sf1 null mutants adrenal glands and gonads are absent, due to increased programmed cell death in the cell populations that normally give rise to these tissues (Luo et al., 1994), causing the death of mice very early in postnatal life. In the $X Y$ gonad, the failure of testis differentiation results in persistence of Müllerian structures at birth. Prior to regression of the gonad rudiment in the Sf1 homozygous knockout, primordial germ cells are detectable in the gonadal ridge (Luo et al., 1994). Thus, the primary role of $S f 1$ in gonad development involves the

somatic cell lineages. Even heterozygous mutation of the SF1 gene has been associated with $46, \mathrm{XY}$ sex reversal and adrenal failure in humans (Achermann et al., 1999).

\section{WT1}

WT1 is a zinc finger gene which is mutated in a proportion of nephroblastomas, an embryonic kidney tumor found in 1 of 10,000 newborn. During development, the 
WT1 gene is expressed in the bipotential gonad and then becomes localized in the Sertoli cells of the testis and granulosa and epithelial cells of the ovary (Pritchard et al., 1990; Pelletier et al., 1991). In vitro and in vivo studies suggest that WT1 can act as both a transcriptional repressor (Menke et al., 1998) and activator (Lee et al., 1999). It has at least 24 different isoforms; of particular interest are the two KTS isoforms, +KTS and -KTS, depending on alternative splice donor sites at the end of exon 9, leading to the insertion or omission of three amino acids (KTS) between zinc fingers 3 and 4 . The alternative splice site is highly conserved during evolution and can be found in all vertebrates (Kent et al., 1995; Miles et al., 1998). Increasing evidence indicates that +KTS and -KTS isoforms serve distinct functions within the nucleus. -KTS isoforms are generally more active in transcriptional regulation; to date, a number of genes including Sf1 have been shown to be activated by -KTS in vitro. On the other hand +KTS products have been shown to colocalize with splicing factors and associate with spliceosomes (Larsson et al., 1995; Ladomery et al., 1999; Englert et al., 1995). Biochemical studies show different properties of WT1 isoforms in their interaction with other proteins: e.g., the splicing factor U2AF65 has a stronger affinity to +KTS variants (Davies et al., 1998), whereas steroidogenic factor 1 SF1 binds preferentially to -KTS isoforms (Nachtigal et al., 1998). The two isoforms also differ in their binding affinity to nucleic acids. Indeed, in vitro studies (Caricasole et al., 1996) and computer modeling (Kennedy et al., 1996) suggest that +KTS proteins can bind to RNA and it has been speculated that they may play a role in posttranscriptional modification. Finally, NMR relaxation experiments demonstrate that the insertion of the KTS sequence leads to an increased linker flexibility and loss of DNA binding of zinc finger 4 , hence providing a molecular basis for the differential affinity of + and -KTS variants to DNA (Laity et al., 2000). Wt1 plays important roles in differentiation of bipotential gonad in both sexes; it is required for the survival and differentiation of gonadal cells. WT1 regulates Dax-1 via GCrich binding sites upstream of the Dax-1 TATA box (Kim et al., 1999). Wt1 appears to turn on Sry expression and subsequently be turned off by Sry expression. In addition to its roles at the bipotential stage, $W t 1$ is essential at multiple steps in 
testicular development: for instance, it is essential for the maintenance of Sertoli cells and seminiferous tubules in the developing testes. Conditional knockout mice in which $W$ t 1 function was ablated specifically in Sertoli cells at $14.5 \mathrm{dpc}$ resulted in disruption of developing seminiferous tubules and subsequent progressive loss of Sertoli cells and germ cells. Particularly, expression of Sox9 in these Sertoli cells was turned off, suggesting that WT1 regulates Sox9, either directly or indirectly, after Sry expression comes to an end (Gao et al, 2006). Recently it has been demonstrated that $W t 1$ and $A m h r 2$ (AMH receptor 2) are coexpressed during urogenital development and that the WT1-KTS protein binds to specific sites in the promoter region of the Amhr2 gene. AMHR2 is an essential factor for the regression of the Müllerian duct in males, indicating a novel function for Wt1in Müllerian duct regression (Klattig et al., 2007).

\section{b. Genes involved in testicular differentiation downstream of $S R Y$}

\section{sox9}

SOX9, located on the human chromosome 17, encodes a SRY related HMG boxcontaining factor which is both necessary and sufficient for the differentiation of Sertoli cells (Kent et al., 1996; Morais da Silva et al., 1996). SOX9 was discovered by high-resolution mapping of the breakpoint in one patient with both sex reversal and a severe skeletal malformation syndrome known as campomelic dysplasia (CD) (Wagner et al., 1994; Tommerup et al., 1993; Foster et al., 1994). From an evolutionary point of view, SOX9 appears to be highly conserved among mammals as well as in other vertebrate species, such as birds and reptiles (Kent et al., 1996; Morais da Silva et al., 1996; Western et al., 1999). SOX9 mutations occur throughout the Open Reading Frame (ORF), unlike those in $S R Y$ that generally cluster within the HMG box. Mutations in the SOX9 ORF outside the HMG box are nonsense and frameshift mutations that disrupt the C-terminal domain of the protein and alter the ability of SOX9 to efficiently activate transcription of target genes (Sudbeck et al., 1996; $\mathrm{Ng}$ et al., 1997; McDowall et 
al., 1999). SOX9 mutations include splice acceptor/donor changes and missense, nonsense, translocation, and frameshift mutations (Wagner et al., 1994; Foster et al., 1994; McDowall et al., 1999; Meyer et al., 1997; Kwok et al., 1995; Hageman et al., 1998). There is no correlation between severity of the disease or associated sex reversal and mutation type with many of the same mutations causing varying degrees of gonadal dysgenesis and bone malformations (Kwok et al., 1995). Sox9 is expressed first at low levels in the indifferent gonad of both sexes, but becomes dramatically upregulated in Sertoli cells after the onset of Sry expression in a very similar spatio-temporal pattern to Sry (Harley et al., 2003). However, in contrast to Sry, Sox9 expression is maintained in Sertoli cells until after birth. SOX9 contains two well defined transactivation domains and has been implicated in the upregulation of several genes such as MIS and Vanin-1. As well, SOX9 binds to the Prostaglandin D Synthase (Pgds) gene promoter and regulates its transcription in vivo to ensure testis development (Wilhelm et al., 2007a). On the contrary, another study showed that Prostaglandin D2 induces nuclear import of the SOX9 via its CAMP-PKA phosphorylation (Malki et al., 2005). Sox9 is responsible for the maintenance, but not initiation of $S f 1$ expression in Sertoli cells. Consequently Sox9 with Sf1 regulate Amh (MIS) and Vanin-1 activation in Sertoli cells. Another putative target of SOX9 could be fibroblast growth factor 9 (Fgf9), recently shown to have a crucial role in testis differentiation (Colvin et al., 2001).

\section{PGD2}

Prostaglandin D2 (PGD2), produced by Prostaglandin D synthase ( $P g d s)$, is synthesized in many organs and has been implicated as a signalling molecule in the mediation or the regulation of various biological processes including platelet aggregation, bronchoconstriction and allergic diseases (Matsuoka et al, 2000; Breyer \& Breyer, 2001). PGD2 interacts with two receptors, the specific membrane-bound DP receptor associated with adenylcyclase and intracellular CAMP production (or DP1) (Boie et al, 1995; Breyer \& Breyer, 2001), and a novel 
receptor, CRTH2 (chemo attractant receptor T helper type 2 (Th2) cells) (or DP2), which is coupled to $\mathrm{Ca}^{2}+$ signalling (Hirai et al, 2001; Monneret et al, 2001). Pgds is expressed in Sertoli cells immediately after the onset of Sox9 expression. Subsequently, PGD2 acts as a paracrine signal by recruiting the supporting cell lineage to the Sertoli cell fate in order to ensure that Sertoli cell differentiation reaches a certain threshold to induce normal testis development (Wilhelm et al., 2007). It masculinises $11.5 \mathrm{dpc} X X$ gonads and induced MIS expression, a Sertoli cell marker in culture (Adams and McLaren, 2002). However, PGD2 is considered as an autocrine factor for $S O X 9$; it induces SOX9 nuclear translocation via its protein kinase A (PKA) phosphorylation in NT2/D1 cells, which is modulated via DP1 receptor of PGD2 and the subsequent stimulation of the CAMP pathway (Malki et al., 2005).

\section{MIS}

The existence of MIS was first suggested by Alfred Jost in the 1940s. MIS is synthesised as a 575 (bovine) or 560 (human) amino acid precursor with a 24-25 amino acid leader containing a 16-18 amino acid signal sequence and a putative 7-8 residue pro-sequence. The carboxyl-terminal region of MIS shares homology with that of members of the transforming growth factor $\beta$ (TGF- $\beta$ ) superfamily. The human MIS gene was mapped on chromosome 19 p13.3 (Cohen-Haguenauer et al., 1987); it encompasses five exons characterised by a high GC content. The mouse Mis promoter contains an almost perfect TATA box, while the human one lacks consensus TATA or CCAAT box elements. Human MIS transcript has been shown to contain a functional initiator (Inr) element that is specifically recognised by transcription factor TFII-I (Morikawa et al., 2000). More recently a housekeeping gene, named, was found which encodes for one spliceosome protein, at -789 from the human MIS ATG codon (and -434 in the mouse). The finding of SAP62/SF3A2 has led to the identification of binding elements for SOX/SRY proteins (Haqq et al., 1993, 1994; de Santa Barbara et al., 1998), SF-1 (Shen et al., 1994; Watanabe et al., 2000) and GATA factors (Tremblay and Viger, 
1999; Watanabe et al., 2000; Beau et al., 2000). MIS is the first factor secreted by differentiated Sertoli cells in the testis, and causes the Müllerian duct regression in males (Behringer et al., 1990) by triggering a BMP-like signalling pathway through MIS type II receptor (MISIIR) and probably the type I receptor ALK2 (Roberts et al., 2002). The MISIIR is expressed in the mesenchyme surrounding the Müllerian duct in $X Y$ and $X X$ animals, and in Sertoli and granulosa cells in embryonic and adult testes and ovaries, respectively. This regression can be an indirect effect because these receptors are expressed in the mesenchymal cells surrounding the Müllerian duct, but apoptosis is induced in cells of the Müllerian duct epithelium. Recently, MMP2, a member of the extracellular matrix metalloproteinase family, has been identified as a candidate target of MISIIR signalling. It seems to function as a paracrine death factor causing apoptosis in the epithelial cells (Roberts et al., 2002). Interestingly, male mice carrying null alleles for Mis retain their Müllerian ducts but develop normal testes. Therefore, Mis does not seem to have an essential role during male gonad development (Behringer et al., 1994). It has been reported that MIS can induce migration from the mesonephros into XX gonads in vitro, yet in gonads from Mis null mutant mice, migration occurs normally. Therefore, if MIS has a role in mesonephric cell migration in vivo, it is redundant with other TGF- $\beta$ family members (Ross et al., 2003).

\section{FGF9}

FGF9 encodes a signaling molecule involved in gonadal proliferation. There seems to be a positive interaction between Sox9 and Fgf9. Besides, Fgf9 is thought to antagonize the up-regulation of Wnt4 in XY gonads (Kim et al., 2006). Indeed, its invalidation in mice leads to male to female sex reversal with phenotypes ranging from testicular hypoplasia to complete sex reversal. The main role of Fgf9 in testis differentiation is to control mesonephric cell migration into the $X Y$ gonad. More than $80 \%$ of the Fgf9 null mutant XY mice do not express Sertoli cell markers, such as Sox9 and Amh and fail to form testis cord structures so that they develop as sex-reversed females (Colvin et al., 2001). Fgf9 is essential for 
two events in early testis development at about $11.5 \mathrm{dpc}$; to increase the proliferation of pre-Sertoli cells, and to localize an FGF receptor (FGFR2) in the nucleus of differentiating Sertoli cells. In fact, the nuclear localization of FGFR2 overlaps with the expression of Sry in Sertoli cells and colocalizes with SOX9, although growth factor receptors have been seen in the nuclei of cultured cells (Goldfarb, 2001; Wells and Marti, 2002).

\section{c. Other important genes}

Other members of three signalling pathways that play a role in early testis formation include platelet derived growth factor receptor alpha (Pdgfr- $\alpha$ ) (Brennan et al., 2003), Desert hedgehog (Dhh) (Yao et al., 2002) and the insulin growth factor receptors (Nef et al., 2003). XY mice homozygous for deletions of Pdgfr- $\alpha$ or Dhh exhibit abnormalities in the structural development of the testis and in the differentiation of the Leydig cells, but they do not show primary defects in Sertoli cell differentiation, and they are not sex reversed. Thus, although Pdgfr- $\alpha$ and Dhh are necessary for testis development, they are not crucial for Sertoli cell differentiation and the primary commitment to the testis fate. It has been shown that Pdgfr- $\alpha$ expression in gonadal cells is important for the mesonephric cell migration. More recently expression profiling of genital ridges and pre-Sertoli cells at the time of sex determination and early sexual differentiation by microarray have revealed novel candidate genes (Nef et al., 2005, Beverdam \& koopman, 2006; Bouma et al., 2007; Clement et al., 2007; Cory et al., 2007)

\section{d. Genes involved in ovarian pathway}

Though less studied, indeed, ovarian development must involve the coordinated activity of a large number of genes. Of particular note are the possible roles of four genes likely to be involved in early development of the ovary; Wnt4, Dax1, Fst, and Foxl2. 


\section{WNT4}

WNT4 is conserved throughout vertebrates and was originally studied in nonmammalian vertebrates such as zebrafish, chicken and Xenopus (Hollyday et al., 1995; Ungar et al., 1995). In these species, WNT4 is expressed in the developing brain and appears to play a crucial role in inhibiting cell movement during embryogenesis (Hollyday et al., 1995; Ungar et al., 1995). In mammals, WNT4 function was initially studied during nephrogenesis in the metanephric kidney as mice lacking Wnt4 die shortly after birth due to kidney failure (Stark et al., 1994). Besides, Wnt4 is required for mesenchymal to epithelial transformation, an essential step in kidney tubule formation (Kispert et al., 1998). More recently, it was observed that Wnt 4 is also expressed in the mesonephros and the gonad and its expression is in close association with the Müllerian duct. This observation indicated that Wnt4 may be important for the development of the reproductive system (Bernard \& Harley, 2007). Wnt4 is expressed in the embryonic gonad of both sexes at early stages of development and after the action of Sry in the XY gonad its expression becomes ovary specific (Vainio et al., 1999). Expression of Wnt4 is first observed in the mesonephric mesenchyme and coelomic epithelium from $9.5 \mathrm{dpc}$ onwards. At $11 \mathrm{dpc}$, Wnt4 is expressed in the mesenchyme of the indifferent gonad and the mesonephroi of both sexes, but is downregulated in the male gonad $12 \mathrm{~h}$ later. The Wnt4 expression persists in the mesonephroi as well as in the female gonad and the mesenchyme surrounding the Müllerian ducts (Stark et al., 1994; Vainio et al., 1999). Wnt4 seems to have several roles in sexual differentiation; Wnt4 inhibits the migration of adrenal precursors and endothelial cells into the developing XX gonad, preventing both the formation of a male-specific coelomic blood vessel and ectopic steroid production (Jeays-Ward et al., 2003; Vainio et al., 1999), suggesting that Wnt4 acts to positively regulate ovary differentiation. Wnt4 null mutant $X X$ mice show partial sex reversal; masculinisation, a massive loss of germ cells by apoptosis (that at $16.5 \mathrm{dpc}$ depletes the entire pool of oocytes) and ectopic expression of enzymes involved in steroid hormone biosynthesis. In these animals the gonad has the appearance of 
a testis: round, unencapsulated, and associated with a fat body; the Müllerian ducts are missing and the Wolffian ducts further differentiate. However, the gonads do not form testis cords or express Sertoli cell-specific markers (Vainio et al., 1999). In male mice which ectopically express Wnt4 proper testicular vascular development and androgen production is absent. However, in these mice Leydig cells differentiate and the gonad still forms a coelomic vessel, but the structure and the branching of coelomic vessel are abnormal (Jeays-Ward et al., 2003; Jordan et al., 2003). This suggests that either WNT4 is not the only factor responsible for repressing male-specific vascularization in the ovary, or testes express a factor that can overcome, at least in part, WNT4 mediated repression. WNT4 seems to exert these functions via the upregulation of follistatin, as suggested by expression and null mutation analysis (Yao et al., 2004).

\section{DAX1}

DAX1 (DSS AHC critical region on the $X$ chromosome, gene 1) (Muscatelli et al., 1994) also known as NROB1 (nuclear receptor subfamily 0 , group $B$, member 1 ), an orphan receptor belonging to the superfamily of nuclear receptor transcription factors, is composed of two exons that encode a 470 amino acid protein. DAX1 is unusual among nuclear receptors because it lacks the highly conserved zincfinger DNA-binding domain (Zanaria et al., 1994). Instead, the amino terminus of DAX1 contains a repeated peptide sequence comprising variations of a hydrophobic LXXLL-like motif (Zhang et al., 2000) that mediates protein-protein interactions (Suzuki et al., 2003). DAX1 may bind to certain DNA hairpin structures and to RNA (Lalli et al., 2000), but its major transcriptional regulatory action involves direct interactions with other nuclear receptors, including SF1 (Holter et al., 2002; Ito et al., 1997; Zhang et al., 2000). The carboxyl terminus of DAX1 contains a transcriptional repressor domain (Ito et al., 1997; Zazopoulos et al., 1997) that interacts with several different co-repressors (Altincicek et al., 2000; Crawford et al., 1998). The $\mathrm{N}$-terminal region of DAX1 is thought to serve as a DNA-binding domain and the $\mathrm{C}$-terminal region contains a putative ligand-binding 
domain (Bae et al., 1996). In humans and mice, DAX1/Dax1 is expressed throughout the hypothalamic-pituitary-adrenal/gonadal axis (Ikeda et al., 1996; Hanley et al., 2000; Ikeda et al., 2001). Although DAX1 represses the transcriptional activating potential of a number of proteins through protein-protein interaction (Clipsham \& McCabe, 2003), it is possible that DAX1 has additional functions, such as directly mediating gene expression by binding to DNA or RNA (Ludbrook and Harley, 2004). XY humans with a duplication of $D A X 1$, a $160 \mathrm{~kb}$ region on chromosome $\mathrm{Xp} 21$ exhibit gonadal dysgenesis and develop ambiguous or female external genitalia (Bardoni et al., 1994), a condition known as dosesensitive sex-reversal (DSS). Alternatively, a mutation within or a complete deletion of this chromosomal region causes $\mathrm{X}$-linked adrenal hypoplasia congenita $(\mathrm{AHC})$ in which $X Y$ individuals develop adrenal insufficiency and hypogonadotropic hypogonadism $(\mathrm{HH})$, leading to delayed puberty (McCabe, 2001). It was originally thought that $D A X 1$ was an ovarian determining gene, based on sex reversal data in humans (Bardoni et al., 1994; Swain et al., 1996). More recent studies, however, have challenged this view and suggested that Dax1 is involved in testicular development. One model of SF1 and DAX1 action proposes that the $\mathrm{N}$ terminus of DAX1 interacts with $\mathrm{SF} 1$, and recruits repressors to the SF1 transcription complex, thereby inhibiting the expression of SF1regulated genes such as Star, Dax1, Lhb, 3BHSD (Hsd3b - Mouse Genome Informatics), Cyp19, Cyp11a1 and Mis (Lalli et al., 1998; Nachtigal et al., 1998; Salvi et al., 2002; Suzuki et al., 2003; Tabarin et al., 2000; Wang et al., 2001; Zazopoulos et al., 1997). Another model suggests that although SF1 and DAX1 function as transcriptional antagonists for many target genes in vitro, they act independently or cooperatively in vivo to enhance the expression of the Sertoliderived factors $D h h$ and $A m h$, mediating somatic cell differentiation during testis development (Park et al., 2005). Three studies have dealt with loss of Dax1 function. The first report investigated gonad development in $129 \mathrm{~Sv} / \mathrm{J}$ mice containing a Dax1 exon 2 (ligand-binding domain) deletion (Dax1-). Heterozygote adult males for this Dax1 mutation had smaller than normal testes with impaired testicular germinal epithelial development and eventual germ cell loss (Yu et al., 
1998). By contrast, homozygous Dax1- mice were fertile females. A second study examined testicular development in fetal 129Sv/J Dax1-/Y mice (Meeks et al., 2003a). Testis development appeared to progress normally until E13.5, when some testis cords appeared disorganized and incomplete. The third study examined the effects of the Dax1- allele in mice containing a mixed genetic background and a Mus domesticus poschiavinus $Y$ chromosome $\left(Y^{\text {POS }}\right.$ ) (Meeks et al., 2003b). Combining a 'weaker' Sry (sex-determining region of chromosome $Y$ ) allele on $Y^{\text {POS }}$ (Eicher et al., 1995) and Dax1- caused sex reversal in Dax1-/YPOS mice (Bouma et al., 2005).

\section{FST}

FST (Follistatin) encodes an activin binding protein known to regulate the hypothalamic-pituitary- gonadal axis (Phillips and de Kretser, 1998). Fst acts downstream of Wnt4 to inhibit the formation of the coelomic vessel and to maintain germ cell survival in the cortical domain of the ovary. The same as Wnt4 null mutant mice, Fst null mutants form coelomic vessels and lose germ cells (Yao et al., 2004). Without Wnt4 or follistatin, female germ cells enter meiosis normally but undergo massive apoptosis at E16.5, leading to loss of the entire population at birth. Intriguingly, germ cell apoptosis normally occurs in the medullary region of the ovary, whereas in the affected ovaries, apoptotic germ cells appear in both medullary and cortical regions (Vainio et al., 1999; Yao et al., 2004). The WNT4/follistatin signaling cascade is unique in that it has both anti-testis (inhibition of the coelomic vessel) and pro-ovary properties (survival of meiotic germ cells). WNT4 and follistatin produced by somatic cells seem to create a protective niche in the ovarian cortex to maintain survival of female germ cells, which may explain why under normal circumstances, follicle formation occurs primarily in the cortex of the ovary. These two molecules represent the first organized signalling cascade in early ovarian development (Cederroth et al., 2007). 


\section{FOXL2}

FOXL2 is a single-exon gene encoding a transcription factor with a "forkhead" DNA binding domain. As well the protein has a polyalanine tract $(n=14)$ with a currently unknown function. Noteworthy, $30 \%$ of mutations consist in the expansion of this poly-ALA tract. The FOXL2 gene is highly conserved among all studied vertebrates; however its conservation is more distinct in the C-terminal domain rather than in the N-terminal part of the protein. In humans, the FOLX2 protein is expressed in the nucleus of fetal eyelid muscular cells and in mesenchymal pregranulosa cells and later in granulosa cells before its expression ceases postnatally (Schmidt et al. 2004). On the contrary, FOXL2 could be detected neither in the oocyte nor in the fetal or adult testes in the human, mouse, goat, chicken and fish (Govoroun et al., 2004; Baron et al., 2004). Heterozygous Fox/2+1- mice have a normal phenotype. However, Fox/2 null mutant mice present eyelid malformation and the females develop sterility while males remain fertile. Fox/2 null mutant $X X$ mice display a normal ovarian differentiation at birth, but later they develop premature ovarian failure. This failure is due to altered differentiation of granulosa cells which are not able to form follicles (Uda et al., 2004; Schmidt et al., 2004). FOXL2 also has been implicated in a human congenital disease, blepharophimosis-ptosis-epicanthus inversus syndrome (BPES) (Crisponi et al., 2001), which is characterized by eyelid abnormalities and is often associated with premature ovarian failure, implying a functional role in ovarian development or maintenance (Wilhelm et al., 2007). Furthermore, FoxL2 plays a role in the autosomal $X X$ sex reversal phenotype of the polled intersex syndrome in goats (Pailhoux et al., 2002). FOXL2 represses male sex determination; goats with FOXL2 deletion showed both a lack of horns (thought to be homologous to the eyelid anomalies in BPES) and XX maleness (polledintersex, PIS) (Pailhoux et al., 2001). Interestingly, a male differentiation program is indeed initiated in Fox/2 null mutant female mice, indicating that Fox/2 may function as a conserved repressor of the genetic program for somatic testis determination in mammals (Ottolenghi et al., 2005). 


\subsection{TAT technology}

Protein transduction with cell penetrating peptides over the past several years has been shown to be an effective way of delivering proteins in vitro and now several reports have also shown valuable in vivo applications in correcting disease states. An impressive bioinspired phenomenon of crossing biological barriers came from HIV transactivator TAT protein. In 1988, Green and Frankel independently discovered HIV TAT protein is able to cross cell membranes (Green \& Loewenstein, 1988; Frankel \& Pabo, 1988). In 1994, Fawell et al. demonstrated that chemically cross-linking a 36-amino acid domain of TAT to heterologous proteins conferred the ability to transduce into cells (Fawell et al., 1944). It was also shown that PTD-beta-gal fusion protein applied intraperitoneally entered the brain after crossing the blood-brain barrier (BBB) (Schwarze et al., 1999). Subsequently, several other studies have also reported effective biodistribution of therapeutically important proteins in vivo by using PTD (Dietz et al., 2004; Soane \& Fiskum, 2005). Other transduction domains were identified that reside in the Antennapedia (ANTP) protein from Drosophila and HSV VP22 protein from HSV.

Specifically, the protein transduction domain of HIV TAT has been shown to be a potent pleiotropic peptide in protein delivery. In the first exon of HIV TAT, a region coding for the basic domain from 48 to 56 amino acid residues is responsible for nuclear localization and protein transduction (Vives et al., 1997: Fawell et al., 1944: Nagahara et al., 1998).

Several studies have reported strong protein transduction property in vivo and in vitro after fusion with various full length or truncated proteins (Dietz et al., 2004). It has also been reported that TAT fusion protein can direct the peptides to the nucleus of a variety of mammalian cells ( $\mathrm{Li}$ et al., 2003).

Various approaches such as molecular modeling, arginine guanidinium head group structural strategy, multimerization of PTD sequence and phage display system have been applied for taming of the PTD. This has resulted in identification of PTD variants which are efficient in cell membrane penetration and cytoplasmic 
delivery (Chauhan et al., 2007). In spite of these state of the art technologies, the dilemma of low protein transduction efficiency and target specific delivery of PTD fusion proteins remains unsolved. Moreover, some misconceptions about PTD of TAT in the literature require considerations. 


\section{Hypothesis}

Based on TAT fusion protein technology and the fact that mouse SRY protein needs to be intact in order to initiate testicular differentiation, we hypothesized that TAT-SRY protein, which contains the whole SRY protein, could induce testicular differentiation in $X X$ gonads. In addition, we anticipated the testicular differentiation in $X Y$ gonads to be impaired by the presence of TAT-HMG, a dominant-negative mutant SRY protein, for the following reasons. TAT-HMG contains only DNA binding motif of SRY protein, thus, we assumed that it would compete with the endogenous SRY in binding to its target site on DNA. Besides, TAT-HMG lacks the bridge and glutamine rich regions which are required for the proper coordination of SRY Interacting Proteins (SIPS) and testicular differentiation in mouse.

In accordance with our results we assumed that the disturbance of differentiation was the effect of DMSO and not TAT-HMG and we speculated that TAT-HMG was acting at SRY level and DMSO was acting downstream of SRY upstream of SOX9 to support testicular differentiation.

We then attempted to rescue testicular differentiation by one of the candidates which act at the same level or upstream of DMSO, PDG2. It has been reported that PGD2 is able to induce testicular differentiation in culture, but it is not clear whether it acts upstream or downstream of SOX9. Based on our preliminary results, we predicted that PGD2 may act upstream of SOX9 and rescue Sertoli cell differentiation and cord formation in the $X Y$ gonads when treated with DMSO. 


\section{Materials and methods}

\subsection{Expression and purification of TAT-fusion proteins}

TAT fusion proteins were made and purified by our collaborators Yunmin $\mathrm{Li}$ and Y.-F. Chris Lau (Department of Medicine, VA Medical Center, University of California, San Francisco, California) according to the following protocol. The HMG domain of the B6 mouse Sry gene was amplified by PCR, and inserted into the plasmid PTAT-HA at Ncol and Xhol sites. The resultant fusion protein was named pTAT-HMG. The entire Sry gene of the CD1 mouse was processed likewise to prepare the TAT-SRY fusion protein. The pTAT-[HMG or Sry] was then transfected into BL21(DE3)pLysS cells, a single colony was selected from the plate and inoculated in $50 \mathrm{ml}$ LB medium containing $0.1 \mathrm{mg} / \mathrm{ml}$ ampicillin in a 250 $\mathrm{ml}$ flask and incubated at $37^{\circ} \mathrm{C}$ until the $\mathrm{OD}_{600}$ reached approximately 1 . The culture was then stored at $4^{\circ} \mathrm{C}$ overnight. The next morning, the cells were collected by centrifugation, resuspended in $500 \mathrm{ml}$ fresh LB medium containing $0.1 \mathrm{mg} / \mathrm{ml}$ ampicillin, and further cultured until $\mathrm{OD}_{600}$ reached 0.6. TAT-HMG expression was induced by adding $1 \mathrm{mM} I \mathrm{PTG}$, followed by incubation at $37^{\circ} \mathrm{C}$ for 4-5 hours. The bacteria cultures were chilled on ice and processed subsequently at $4^{\circ} \mathrm{C}$. They were harvested by centrifugation and washed with cold PBS. The pellets were resuspended in $10 \mathrm{ml}$ of PBS containing a protease inhibitor cocktail (Roche Diagnostics, Indianapolis, IN), and lysed by sonication. Inclusion body was washed with $1 \%$ Triton $\mathrm{X}-100,50 \mathrm{mM}$ Tris- $\mathrm{HCl}(\mathrm{pH} 8.0), 150 \mathrm{mM} \mathrm{NaCl}$ for 3 times, then washed with $50 \mathrm{mM}$ Tris- $\mathrm{HCl} \mathrm{pH} 8.0,150 \mathrm{mM} \mathrm{NaCl}$ to remove the Triton $\mathrm{X}$ 100. TAT-HMG inclusion body was dissolved in $90 \%$ dimethyl sulfoxide (DMSO) (Fisher Scientific), $50 \mathrm{mM}$ Tris- $\mathrm{HCl} \mathrm{pH} \mathrm{7,} \mathrm{and} \mathrm{insoluble} \mathrm{fraction} \mathrm{was} \mathrm{removed} \mathrm{by}$ centrifugation. DMSO served as the solvent of protein and protein concentrations were determined by SDS-PAGE and Coomassie Blue staining in comparison with known amounts of bovine serume albumin (BSA) (Sigma-Aldrich, St. Louis, MS) as a standard. 


\subsection{Organ culture}

\section{Tissue collection}

All animal procedures were performed in accordance with the Canadian Council on Animal Care and approved by the McGill University Animal Care Committee. CD1 mice were purchased from Charles River Laboratory (St. Constance, QC, Canada). Females were caged with males up to 3 days, and separated from the males on the morning when copulation plugs were identified. The gestation age was defined as dpc, assuming that the copulation occurred at 1:00 AM. As gonad development progresses rapidly in a day and the developmental stage may differ among litters, the number of tail somites (ts) was counted from the end of the tail to genital tubercle to identify the accurate developmental stage of each fetus. In the CD1 strain, 10-12, 13-23 and 24-28 ts-stages corresponded to $10.5 \mathrm{dpc}$, 11.5 and $12.5 \mathrm{dpc}$, respectively. Gonadal primordia with adjacent mesonephroi (=urogenital complexes) were isolated from mouse fetuses at 10.5-13.5 dpc in Eagle's MEM (Minimum Essential Medium) with Hank's salts containing $25 \mathrm{mM}$ Hepes buffer (both from Invitrogen/GIBCO, Long Island, NY). Gonads at 12.5-13.5 dpc were used as in vivo controls.

\section{Organ Culture}

Immediately after isolation, one gonad of each pair at 10.5-11.5 dpc was cultured and submerged in MEM with Earle's salt containing $1 \mathrm{mM} \mathrm{L-glutamine,} 10 \%$ heatinactivated horse serum and penicillin and streptomycin antibiotics (all from Invitrogen(GIBCO) for up to three days at $37^{\circ} \mathrm{C}$ and $5 \% \mathrm{CO}_{2}$, served as an untreated control. The other gonad of the same pair was incubated in the same medium and condition plus one of the fusion proteins dissolved in DMSO (Fisher Scientific), served as the treated one. Some gonads were also treated with the basic medium containing DMSO alone or DMSO plus prostaglandin D2 (ptgD2) (Sigma-Aldrich, St. Louis, MS). 


\subsection{Sexing}

The sex of gonads at 12.5 and $13.5 \mathrm{dpc}$ was identified by morphological characteristics. The sex of gonads at $10.5-11.5 \mathrm{dpc}$ was identified by PCR amplification of $Y$-specific $Z F Y$ sequence. A small piece of head was collected at the time of gonadal dissection and incubated overnight in lysis buffer $[0.05 \mathrm{M} \mathrm{KCl}$, $0.05 \mathrm{M}$ Tris at $(\mathrm{pH} 8.3), 0.1 \mathrm{mg} / \mathrm{ml}$ gelatin, $0.45 \%$ Nonident $\mathrm{P}-40,0.45 \%$ Tween and $60 \mu \mathrm{g} / \mathrm{ml}$ Proteinase $\mathrm{K}]$ at $55^{\circ} \mathrm{C}$. The lysates were then incubated at $95^{\circ} \mathrm{C}$ for $10 \mathrm{~min}$ to inactivate Proteinase K. $5 \mu$ of 1:10 diluted lysate served as DNA template for a 35 cycle repeat $\mathrm{PCR}$ (annealing temperature $=60^{\circ} \mathrm{C}$ ), using Taq DNA polymerase kit and the following set of Zfy primers $\left(5^{\prime} \rightarrow 3^{\prime}\right)$ (Invitrogen):

\section{F: AAGATAAGCTTAGATAATCACATGGA}

\section{R: CCTATGAAATCCTTTCGTGCACATGT}

The reaction mix was then kept at $4{ }^{\circ} \mathrm{C}$ until running on $2 \%$ agarose gel containing ethidium bromide for electrophoresis analysis. The presence of the $Y$ chromosome gave a 618 base pair (bp) amplificon; $X Y$ male, $X Y$ and $X X$ females were used as controls (Nagamine et al., 1989).

\subsection{Immunohistochemistry}

\section{Histology slide preparation}

After culture, all gonads were fixed with $2 \%$ formaldehyde (Electron Microscopy Sciences, Hartford, PA) in a microtubule stabilizing buffer (Messinger and Albertini, 1991) for 1 hour at room temperature, and stored in $70 \%$ ethanol at $4^{\circ} \mathrm{C}$ until being embedded in paraffin. Gonads at 12.5 and $13.5 \mathrm{dpc}$, served as in vivo controls, were fixed immediately after dissection in the same way. Serial paraffin sections of $6 \mu \mathrm{m}$ thickness were placed on Plus-coated histology slides (Fisher Scientific) and stored in a box containing silica gel at $4^{\circ} \mathrm{C}$. Selected slides were deparaffinised in toluene and hydrated through descending concentrations of 
ethanol, the antigens retrieval was performed through incubation in TBS $(\mathrm{pH} 7.6)$ at room temperature for $10 \mathrm{~min}$ followed by $50 \mathrm{mM}$ Tris- $\mathrm{HCl}(\mathrm{pH} 10)$ at $95^{\circ} \mathrm{C}$ for 30 min (Taketo et al., 2005). Slides were then cooled down and washed with deionized water to be processed for immunological staining.

\section{a. HA staining}

After antigen retrieval the slides were washed twice in PBS and incubated with a mouse anti-HA (HA is a sequence attached to pTAT) antibody (Santa Cruz Biotechnology, Santa Cruz, CA) at 1:500 dilution in PBS containing the protein concentrate provided in the MOM kit (Vector Laboratories, Burlingame, CA) at $37^{\circ} \mathrm{C}$ for $60 \mathrm{~min}$ or longer. The slides were then incubated with a goat anti mouse IgG antibody (Jackson ImmunoResearch, Baltimore) conjugated with fluorescein isothiocyanate (FITC) at $1: 1000$ dilution and $37^{\circ} \mathrm{C}$ for $30 \mathrm{~min}$.

\section{b. MIS-laminin double staining}

The slides were washed twice in PBS and incubated with a goat anti-MIS antibody (Santa Cruz Biotechnology, Santa Cruz, CA) and a rabbit anti-laminin polyclonal antibody (Sigma), both at 1:500 dilutions, in PBS containing the protein concentrate (MOM) at $37^{\circ} \mathrm{C}$ for $60 \mathrm{~min}$ or longer. The slides were then incubated with a donkey anti-goat $\lg$ antibody conjugated with RRX and a donkey antirabbit IgG antibody conjugated with Cy2 (both from Jackson ImmunoResearch, West, Grove, PA) at $1: 1000$ dilution and $37^{\circ} \mathrm{C}$ for $30 \mathrm{~min}$.

\section{c. [SOX9 or SRY]-MIS double staining}

The slides were incubated with the mouse IgG blocking reagent provided in the MOM kit for $60 \mathrm{~min}$, followed by anti-SRY monoclonal antibodies (Mab) (Taketo et al., 2005) or anti-SOX9 mouse Mab (Novus Biologicals, Littleton, CO) and the goat anti-MIS antibody, all at 1:500 dilutions, in PBS containing the protein 
concentrate at $4^{\circ} \mathrm{C}$ overnight. On the next day, all slides were washed with PBS and incubated with the anti-mouse IgG antibody conjugated with biotin provided in the MOM kit and the donkey anti-goat IgG antibody conjugated with RRX. All slides were washed with PBS and incubated with avidin conjugated with FITC (Sigma).

\section{Mounting and Imaging}

All slides were dehydrated and mounted in the Prolong Antifade mounting medium (Invitrogen) containing $0.4 \mu \mathrm{g} / \mathrm{ml}$ 4',6-diamidin-2'-phenylindole dihydrochloride (DAPI) (Boheringer Mannheim, Germany). Fluorescent signals were examined under an epifluorescence microscope (Zeiss, Axiophot, Germany). All images were captured with a digital camera (Retiga 1300, Qlmaging, Burnaby, BC, Canada) and processed with Northern Eclipse digital imaging software, version 6.0 (Empix Imaging, Mississauga, ON, Canada).

\subsection{TdT-mediated dUTP nick end labeling (TUNEL) assay}

After deparafinization and rehydration, the sections were incubated with $20 \mu \mathrm{g} / \mathrm{ml}$ proteinase $\mathrm{K}$ (Roche Diagnostics) in $10 \mathrm{mM}$ Tris/ $\mathrm{HCl}\left(\mathrm{pH} \mathrm{7.4)}\right.$ for $15 \mathrm{~min}$ at $37^{\circ} \mathrm{C}$. The slides were then washed twice in PBS, covered with $50 \mu \mathrm{g}$ of TUNEL reaction mixture provided in the In Situ Cell Death Detection kit, flurescein (Roche Diagnostics) and incubated for $60 \mathrm{~min}$ at $37^{\circ} \mathrm{C}$ in moisture chamber in the dark. The slides were washed twice in PBS and processed for mounting and imaging as mentioned before.

\subsection{Quantitative RT-PCR}

Total RNA purification 
After culture, gonads were snap-frozen in liquid nitrogen and stored at $-80^{\circ} \mathrm{C}$ until RNA purification within 2 days. As well, fetal gonads were dissected at 11.5 and $12.5 \mathrm{dpc}$ and snap-frozen immediately (to be used for the standard curves). Total RNA from each gonad was purified using RNeasy mini kit (QIAGEN, Mississauga, ON) according to the manufacturer's protocol and eluted in $60 \mu \mathrm{l}$ RNase free water. After precipitation of RNA with one-tenth volume of $1 \mathrm{M} \mathrm{NaOAc}(\mathrm{pH} 4.5)$ and 2.5 volume of cold $95 \%$ ethanol, the total RNA was stored at $-20^{\circ} \mathrm{C}$ overnight and then washed with cold $75 \%$ ethanol and dried under vacuum to eliminate any traces of ethanol.

\section{cDNA synthesis}

First strand CDNA was synthesized using $5 \mu$ of total RNA, Superscript ${ }^{\mathrm{TM}}$ II RNase $\mathrm{H}$ - Reverse Transcriptase kit (Invitrogen), 40U/ $\mu$ l RNaseOut ribonuclease inhibitor (Invitrogen) and Hexanucleotides (Roche Diagnostics) in a total volume of $20 \mu \mathrm{l}$. To verify the absence of genomic DNA contamination, an aliquot of each RNA sample was processed without reverse transcription, as Sry and 18s rRNA are intronless genes.

\section{Real-time RT-PCR}

$5 \mu$ of $C D N A$ was used for PCR analysis employing the ${ }^{\mathrm{T}}{ }^{\mathrm{TM}}$ SYBR Green Supermix real-time PCR kit (BioRad, Richmond, CA) in a total volume of 20 or 25 $\mu$ on a Biorad iCycler in a 96-well plate format (annealing temperature at $55^{\circ} \mathrm{C}$ ). All samples were measured as duplicates or triplicates. A standard curve was generated for each gene using serial dilutions of a cDNA pool from several male and female fetal gonads. All samples from one experiment were processed in one plate simultaneously and their transcript levels were normalized to the corresponding transcript levels of 18s rRNA cDNA. Only the values within the linear range of standard curve were used for data analysis. All values were compared to the $\mathrm{XY}$ untreated control for each gene. Primer pairs of genes other 
than Sry and 18s rRNA covered at least one intron. The following primers were selected from the list in the PrimerBank Search:

(http://pga.mgh.harvard.edu/cgi-bin/primerbank/search.cgi)

\begin{tabular}{|c|c|c|c|c|}
\hline Gene & Primers' sequence $\left(5^{\prime} \rightarrow 3^{\prime}\right)$ & Length & Location & $\begin{array}{l}\text { Amplicon } \\
\text { Size }\end{array}$ \\
\hline Sry & $\begin{array}{l}\text { F: GCTGGGATGCAGGTCGAAAA } \\
\text { R: GCCACTCСTCTGTGACACTTTAG }\end{array}$ & $\begin{array}{l}20 \\
23\end{array}$ & $\begin{array}{l}114-133 \\
261-239\end{array}$ & 148 \\
\hline Sox9 & $\begin{array}{l}\text { F: AGTACCCGCATCTGCACAAC } \\
\text { R: TACTTGTAATCGGGGTGGTCT }\end{array}$ & $\begin{array}{l}20 \\
21\end{array}$ & $\begin{array}{l}377-396 \\
521-501\end{array}$ & 145 \\
\hline${ }^{*} \mathrm{Mis}$ & $\begin{array}{l}\text { F: TGGTGCTAACCGTGGACTTC } \\
\text { R:AGCCAAATAGAAAGGCTTGCAG }\end{array}$ & $\begin{array}{l}20 \\
22\end{array}$ & $\begin{array}{l}578-597 \\
700-679\end{array}$ & 123 \\
\hline Wnt4 & $\begin{array}{l}\text { F: AGGATGCTCGGACAACATCG } \\
\text { R: CGCATGTGTGTCAAGATGGC }\end{array}$ & $\begin{array}{l}20 \\
20\end{array}$ & $\begin{array}{l}459-478 \\
608-589\end{array}$ & 150 \\
\hline Fgf9 & $\begin{array}{l}\text { F: TCTTCCCCAACGGTACTATCC } \\
\text { R: CCGAGGTAGAGTCCACTGTC }\end{array}$ & $\begin{array}{l}21 \\
20\end{array}$ & $\begin{array}{l}227-247 \\
350-331\end{array}$ & 124 \\
\hline $\begin{array}{l}{ }^{*} 18 s \\
r R N A\end{array}$ & $\begin{array}{l}\text { F: GCCCTGTAATTGGAATGAGTCCA } \\
\text { CTT } \\
\text { R: GTCCCCAAGATCCAACTACGAGC } \\
\text { TTT }\end{array}$ & $\begin{array}{l}26 \\
26\end{array}$ & & 149 \\
\hline
\end{tabular}

All primers were synthesized by Invitrogen. Mis (Amh) primers amplified a nonspecific sequences in addition to the expected one, so a set of Amh Quantitect Primer Assay was ordered from QIAGEN, which gave the same result. The 18s rRNA primers were chosen according to La Salle et al. (2003).

\section{Statistical analysis}

Statistical analysis was made on a total number of 3-9 different sets of $11.5 \mathrm{dpc}$ $X Y$ gonads together with $3 X X$ gonads at each time point in culture. A student $t-$ test was used to calculate the significant differences between two groups. 


\section{Results}

\subsection{Testis cord formation and Sertoli cell differentiation in culture}

We cultured one urogenital complex of each pair, dissected at $11.5 \mathrm{dpc}$ (12-18 tsstages), in the basic medium (=untreated control) and the other urogenital complex of the same pair in the basic medium plus TAT-SRY or TAT-HMG protein (=treated) for 3 days, and then assessed testicular differentiation compared to in vivo control. Expressions of SOX9, MIS and laminin were selected as indicators of testicular differentiation, as expression of SOX9 and MIS proteins is specific to Sertoli cells. Laminin is an extra cellular matrix protein that distinguishes the basal lamina of testis cords.

\section{a. In vivo control}

$\mathrm{XY}$ gonads at 11.5-13.5 dpc were examined for immunolabeling of SOX9, MIS and laminin to detect the time course of Sertoli cell differentiation and testis cord organization in vivo (Fig. 3). Our results showed that in the $X Y$ gonads at early $11.5 \mathrm{dpc}$ a small number of cells were positive for nucleic SOX9 labeling (Fig. 3a). At late $11.5 \mathrm{dpc}$, some cells were positive for cytoplasmic MIS labeling in the central region of the gonad (Fig. 3d), while cord formation was not apparent. At $12.5 \mathrm{dpc}$, the majority of cells within the gonad were positive for SOX9 but they were still unorganized (Fig. 3b). On the other hand, intense MIS labeling in the cytoplasm of Sertoli cells marked the early phase of testis cord organization (Fig. $3 e)$. At $13.5 \mathrm{dpc}$, numerous testis cords were formed within the gonad; SOX9positive Sertoli cells were aligned in a palisade fashion in the peripheral region of testis cords while MIS labeling in the cytoplasm of Sertoli cells was more prominent in the central region (Fig. $3 c$ \& f). Laminin labeling was widely spread outside the testis cords and concentrated along the basement membrane of testis cords. However, it was not prominent when the two labeling were merged. 


\section{b. Untreated control}

3 days after culture in the basic medium, a few to several testis cords were seen in each histological section from all of the examined $X Y$ gonads, though the shape and number of testis cords were not comparable to those of in vivo control; in the in vivo controls more testis cords were seen compared to untreated controls in vitro. Besides, testis cords in vivo were more elliptical while in the untreated controls they took different shapes due to the culture conditions. However, similar to in vivo controls, Sertoli cells were lined up in the peripheral region of testis cords; positive for nucleic SOX9 labeling and cytoplasmic MIS labeling in the gonads after culture (Fig. 4a \& e). For comparison, the XX gonads did not form any particular structure nor were they positive for SOX9 or MIS labeling (not shown).

\section{c. Treatment with TAT-HMG protein}

After 3 days of culture in the basic medium plus $6 \mu \mathrm{g} / \mathrm{ml}$ of TAT-HMG protein dissolved in DMSO (final concentration 1.8\%), XY gonads were positive for SOX9 and MIS labeling with almost the same intensity as the untreated controls, while testis cord organization was severely disrupted in all of the 18 examined gonads. 14 out of 18 examined gonads showed a single island of MIS-positive cells in which SOX9-positive cells were scattered (Fig. $4 d \& h$ ). After treatment with 2 $\mu \mathrm{g} / \mathrm{ml}$ of TAT-HMG protein dissolved in DMSO (final concentration $0.6 \%$ ) testis cord organization was disrupted in all of the 5 examined urogenital complexes (not shown), although not as severely as after the treatment with $6 \mu \mathrm{g} / \mathrm{ml} \mathrm{TAT-HMG}$ protein. Treatment with $0.6 \mu \mathrm{g} / \mathrm{ml}$ TAT-HMG did not cause any difference from those of untreated controls in all 5 examined urogenital complexes (not shown). $X X$ urogenital complexes treated with different concentrations of TAT-HMG

protein neither formed any particular structure nor were positive for MIS labeling ( 3 gonads examined, not shown). 


\section{d. Treatment with TAT-SRY protein}

After 3 days of culture in the basic medium plus 2.0 and $0.6 \mu \mathrm{g} / \mathrm{ml}$ of TAT-SRY protein dissolved in DMSO (final concentrations $0.9 \%$ and $0.3 \%$ respectively), $\mathrm{XY}$ urogenital complexes were positive for MIS labeling with the same intensity as the untreated controls while testis cords were fragmented in all of the 12 examined gonads. Treatment with $0.2 \mu \mathrm{g} / \mathrm{ml}$ TAT-SRY did not cause any difference from those of untreated controls (4 urogenital complexes examined, not shown). When $X X$ urogenital complexes were treated with TAT- SRY protein at $2 \mu \mathrm{g} / \mathrm{ml}$, only 1 out of 10 examined gonads showed a cord like structure with MIS labeling (not shown).

\section{e. Treatment with DMSO alone}

As TAT-fusion proteins were dissolved in DMSO, we examined the effects of DMSO alone on testicular differentiation in culture in comparison to untreated controls. Testicular differentiation was completely blocked in all of the 7 urogenital complexes cultured with $1.8 \%$ DMSO for 3 days. A few cells were positive for SOX9 labeling while there was no sign of MIS expression or testis cord structure. Interestingly, bright and intense laminin labeling was seen along the basement membrane of the surface epithelium, which was not so clear in the untreated control (Fig. 4c \& g). When the dosage of DMSO was decreased to $0.6 \%$ testis cord organization was affected in all of the 5 examined gonads, however, the gonads were positive for SOX9 and MIS labeling (Fig. $4 b$ \& d).

\section{f. Treatment with PGD2}

After 3 days of culture in the basic medium plus $1 \mu \mathrm{g} / \mathrm{ml}$ of PtgD2 and $1.8 \%$ DMSO, in 3 out of 6 examined $X Y$ urogenital complexes testis cords were partially formed and SOX9-positive Sertoli cells were more aligned in the peripheral region than other regions of the gonad while MIS labeling in the cytoplasm of Sertoli cells 
was scattered all over the developing gonad (Fig. 5b). Sertoli cells were better organized compared to treatment with TAT-HMG. The remaining 3 gonads failed to differentiate and there was no sign of testis cord formation or SOX9 and MIS positive cells (not shown). Similar to the treatment with DMSO alone, when 500 $\mathrm{ng} / \mathrm{ml}$ of PGD2 plus DMSO was added to the basic culture medium, few cells were positive for SOX9 labeling while there was no sign of MIS expression or testis cord structure in both of the 2 urogenital complexes examined (not shown).

\subsection{TAT- fusion protein incorporation into gonad}

We tested the TAT- fusion protein integration into urogenital complexes at different time points in culture ranging from $30 \mathrm{~min}$ to 1 day. TAT-SRY protein was rarely detectable within the gonad but often concentrated in the cells on the surface of both $X X$ and $X Y$ gonads, especially on the side of genital ridges (2-4 gonads were examined at each time point; $0.5,1.0,1.5,2.0,2.5,3.0,4.0$ and 24.0 hrs). The incorporation was mainly seen in cytoplasm, although it was occasionally seen in the nucleus. Similar results were obtained when TAT-HMG protein was tested (Fig. 6 a, b, c) (2-4 gonads were examined at each time point; $0.5,1.0,1.5,2.0,2.5,3.0,3.5,4.0$ and $24.0 \mathrm{hrs}$ ).

\subsection{Time course of testicular differentiation in culture}

\section{a. Untreated control}

Intense nucleic SRY labeling was scattered all over a gonad without any clear organization in the 4 examined urogenital complexes cultured for 1 day in the basic medium (Fig. 7a). Gonadal cells in which the SRY labeling was weaker were more positive for cytoplasmic MIS labeling. As well, SOX9 positive cells were scattered in the gonad with equal intensity to one another (Fig. 7e). By the second day, SRY labeling diminished, while MIS labeling became intense within the cytoplasm of Sertoli cells in all of the 8 examined gonads (Fig. 7b). SOX9 
expression remained intense in the gonadal cells in the peripheral segment of the developing testis cords in 4 gonads examined (Fig. $7 f$ ). MIS positive cells were negative for SRY expression, when the two immunolabeled images were merged. Testis cord formation was not complete, although they organized one island of finger-like structures within the developing gonad.

\section{b. Treatment with $6 \mu \mathrm{g} / \mathrm{ml}$ TAT-HMG}

In all of the 4 examined urogenital complexes treated with $6 \mu \mathrm{g} / \mathrm{ml}$ TAT-HMG for 1 day, SRY labeling was intense all over the gonad while MIS labeling was weak or absent (Fig. 7c). There was no sign of cord formation or arrangement of preSertoli cells in the developing gonad and SOX9 labeling was weaker compared to untreated controls (Fig. $7 \mathrm{~g}$ ). By the second day, all of the 8 examined urogenital complexes showed a prolonged SRY labeling in the gonad compared to untreated control, although weaker compared to the first day. In addition, weak MIS labeling appeared in the central region of gonad (Fig. 7d). SOX9 positive cells, with almost the same intensity as the untreated control, were scattered in an unorganized pattern all over the gonad as cord formation was still absent in all 4 urogenital complexes examined (Fig. 7h).

\subsection{Effects of TAT-HMG on gene expression during testicular differentiation}

We examined the effects of TAT-HMG treatment for 1 and 3 days on the transcript levels of Sry, Sox9 and Mis genes as well as those of Wnt4 and Fgf9 genes. To validate our assays, we included XX urogenital complexes in these studies. Sry is the master gene; it initiates the cascade of testicular differentiation in $X Y$ gonads. Sox9 is one of the first genes known to be upregulated after the expression of Sry in XY gonads; it is necessary and sufficient for testis determination. Fgf9 encodes a signaling molecule involved in testis cord formation; it is both necessary for the migration of mesenchymal cells from adjacent mesonephros into gonad and the 
proliferation of pre-Sertoli cells. It seems that Fgf9 antagonizes the up-regulation of Wnt4 in XY gonads. Wnt4 encodes a signaling molecule involved in the ovarian pathway.

The results showed that, neither Sry nor Mis transcripts were detectable in the $\mathrm{XX}$ urogenital complex after culture with or without treatment with TAT-HMG (Fig. 8). Transcript levels of Sox9 in $X Y$ urogenital complexes were higher than transcript levels of Sox9 in XX gonads, similarly transcript levels of Fgf9 in XY urogenital complexes were higher than transcript levels of Fgf9 in XX gonads, in the 3 examined urogenital complexes (not shown). Wnt4 transcript levels in the XX urogenital complex were higher than Wnt4 transcript levels in the $X Y$ in all of the 3 examined urogenital complexes particularly 3 days after culture (not shown). All examined genes were transcribed at higher levels after culture compared to in vivo controls. More variations were observed in gene transcript levels 3 days after culture compared to 1 day. Three concentrations of TAT-HMG - 2.0, 6.0 and 10.0 $\mu \mathrm{g} / \mathrm{ml}$ - were used, and the results indicated that Sry transcription was significantly upregulated in the $X Y$ urogenital complexes in a dosage dependent manner 1 day after treatment $(P<0.01)$. However, 3 days after culture there was no significant difference in the levels of Sry transcript between the treated and untreated groups. On the other hand, Sox9 appeared to be downregulated, again in a dosage dependent manner, 1 day after culture $(P<0.01)$. Sox9 transcription levels showed no major differences between the treated and untreated groups 3 days after culture. No significant changes were detected in the transcript levels of the genes downstream of Sox9 - Mis, Fgf9 and Wnt4 - in XY gonads. In XX gonads 3 days after culture there was a downregulation in Sox9 transcript levels when treated with $2 \mu \mathrm{g} / \mathrm{ml}$ and Wnt4 expression when treated with $6 \mu \mathrm{g} / \mathrm{ml}$ TAT-HMG. Transcript levels of other genes did not show significant changes after treatment with TAT-HMG protein in XX urogenital complexes (not shown).

\subsection{Effects of DMSO alone on gene expression during testicular differentiation}


We examined the transcript levels of Sry, Sox9 and Mis in the urogenital complexes treated with $1.8 \%$ DMSO for 1 day. The results showed that Sry transcript levels were comparable to those in the untreated control (Fig. 9). On the other hand, the transcript levels of either Sox9 or Mis were reduced to almost negligible levels with significant differences $(P<0.05$ and 0.001 , respectively) compared to the untreated controls in all 3 examined urogenital complexes.

\subsection{Cell death}

We processed the urogenital complexes 1 and 3 days after culture for detection of apoptotic cell death by TUNEL. The results showed that in all of the 12 untreated controls examined, 1 and 3 days after culture, several TUNEL positive cells were scattered over the entire $X X$ and $X Y$ urogenital complexes (Fig. 10a). 1 day after treatment with $1.8 \%$ DMSO or $6 \mu \mathrm{g} / \mathrm{ml}$ TAT-HMG dissolved in $1.8 \%$ DMSO, a considerably larger number of TUNEL-positive cells were clustered in the mesonephros near the gonad (Fig. 10b \& c) in all of the 3 and 6 urogenital complexes examined, respectively. After the treatment with either reagents for 3 days, TUNEL-positive cells decreased in number and were scattered over the entire 4 urogenital complexes examined like the untreated control. Similar results were obtained in all of the $3 \mathrm{XX}$ urogenital complexes examined. 


\section{Discussion and Conclusion}

To clarify the molecular mechanism of SRY action during testicular differentiation in mouse, we examined the effects of TAT-SRY and TAT-HMG fusion proteins, dissolved in DMSO, on gonadal differentiation in culture. Our initial results indicated that TAT-SRY was unable to induce testicular differentiation in XX gonads and supported the assumption that TAT-HMG disturbs testicular differentiation. We assumed that the differences between treated and untreated controls originate somewhere in the pathway of testicular differentiation due to the altered function of Sry or the genes downstream. Protein expression and gene transcript levels were tested to identify at which level this impairment happened and what was its effect on the upstream and downstream events. However, we realized later that the impaired testicular differentiation was the effect of DMSO and not TAT-HMG.

\subsection{Sertoli cell differentiation and testis cord formation}

Time course study of gonadal differentiation in vivo (11.5-13.5 dpc) indicated that no distinct structure was seen in the $\mathrm{XY}$ gonads at $11.5 \mathrm{dpc}$. At $12.5 \mathrm{dpc}$ testicular structures were detectable, although not well formed and by $13.5 \mathrm{dpc}$ they were well formed. However, nucleic SOX9 labeling appeared at early $11.5 \mathrm{dpc}$ and remained in evidence while the SOX9-positive pre-Sertoli cells were organized into testis cords. These studies also suggested that MIS protein expression in preSertoli cells preceded testis cord formation in XY gonads; however, it is still ambiguous which one completes earlier; Sertoli cell differentiation or testis cord formation. Similar results were obtained by time course studies of gonadal differentiation in culture (untreated control). Disappearance of SRY labeling in MIS positive Sertoli cells suggested that, the expression of MIS protein in the developing gonad is complementary to the expression of SRY. Where cells were positive for SRY labeling there was no sign of MIS labeling and vice versa. In 
contrast to $X Y$ gonads, we could not detect nucleic SOX9 labeling in the $X X$ gonads in vivo; at $11.5 \mathrm{dpc}$ SOX9 labeling was cytoplasmic and mostly at the membrane of gonadal cells. At $12.5 \mathrm{dpc}$, SOX9 labeling became less intense and again became intense at the membrane by $13.5 \mathrm{dpc}$, however, we were not sure about the specificity of staining.

\subsection{DMSO inhibits testicular differentiation.}

Our results demonstrated that the addition of $1.8 \%$ DMSO to the culture medium completely blocked testicular differentiation in the XY gonads in terms of Sertoli cell differentiation and testis cord formation. This inhibition seemed to happen immediately downstream of Sry and upstream of Sox9 in the pathway of testis differentiation. The results of real-time RT-PCR indicated that 1 day after treatment with $1.8 \%$ DMSO, there was no significant change in Sry transcript levels, while Sox9 transcript levels were reduced severely and Mis transcript levels were almost negligible, compared to untreated control $X Y$ gonads. Immunolabeling experiments indicated that treatment with $0.6 \%$ DMSO only disturbed testis cords organization, while treatment with 1.8\% DMSO had an inhibitory effect on a factor which is either directly involved in the upregulation of Sox9 or mediates the SRY action upstream of Sox9. A candidate for such a factor is prostaglandin D2 (PGD2). PGD2 is considered to induce testicular differentiation through a paracrine signaling pathway; it has been reported that addition of exogenous $P G D 2$ to the $X X$ gonads in culture results in upregulation of MIS and variable levels of masculinization (Adams \& McLaren, 2002). Furthermore, PGD2, via activation of its DP1 receptor and subsequent stimulation of the CAMP pathway, induces SOX9 expression and its nuclear translocation in the mouse XX gonad (Malki et al., 2005; Wilhelm et al., 2005). Besides, the PGD2 synthase (Ptgds), an enzyme required for the final step of PGD2 synthesis, is upregulated concurrently with Sox 9 expression in the mouse $X Y$ gonad consistent with the role of PGD2 in testicular differentiation. However, the relevance in vivo remains unclear since testicular differentiation is not disturbed in the absence of 
genes encoding the Ptgds or two intra cellular receptors for naturally occurring metabolites of PGD2 (PPAR $\alpha$ and NF- $\alpha$ B) (Sha et al., 1995; Barak et al., 1999; Eguchi et al., 1999; Matsuoka et al., 2000). Therefore, we tested the effects of PGD2 on the gonads when treated with DMSO. Our results supported the previous studies; the addition of $1 \mu \mathrm{g} / \mathrm{ml}$ PGD2 overcame the inhibitory effects of DMSO by restoring the expression of SOX9 and MIS. We hypothesized that PGD2 at higher concentrations (e.g. 2-3 $\mu \mathrm{g} / \mathrm{ml}$ ) may rescue testis cord formation, though we have not yet examined it.

\subsection{TAT-SRY failed to induce testicular differentiation}

Immunolabeling of MIS and laminin indicated that addition of $2 \mu \mathrm{g} / \mathrm{ml}$ TAT-SRY fusion protein dissolved in $90 \%$ DMSO (0.9\% final concentration) to the basic culture medium rescued the expression of MIS protein to similar levels as in the untreated control $X Y$ gonads 3 days after culture, although testis cord organization was fragmented. However, except for one gonad that formed a cord like structure with MIS expression, TAT-SRY did not induce testicular differentiation in XX gonads. We assumed that it could be mainly due to the inhibitory effects of DMSO on testicular differentiation and TAT-SRY, and at examined concentrations, was incapable of counteracting this inhibition. Another possibility could be the low efficiency of TAT-SRY in translocation into the nucleus of the gonadal cells. Higher concentrations of TAT-SRY could be more effective.

\subsection{TAT-HMG rescued Sertoli cell differentiation but not testis cord formation}

At first, we expected TAT-HMG to compete with the endogenous SRY in binding to the SRY Interacting Proteins (SIPS) or the SRY target site on DNA. Thus, TATHMG was anticipated to inhibit testicular differentiation, due to the failure of mouse $\mathrm{SRY}$ proteins that lack the glutamine rich region at their C-terminus to act properly (Bowels et al. 1999). However, after we noticed the inhibitory effects of DMSO, we 
realized that TAT-HMG did not inhibit the testicular differentiation but rather supported and rescued SOX9 and MIS expression to the similar levels as in the untreated control $X Y$ gonads 3 days after culture. However, testis cord organization was completely blocked and SOX9 positive cells were scattered all over a large MIS positive island within the gonad. On the other hand, the effects of TAT-HMG on the cultured gonads at lower concentration were the same as those of treatment with $0.6 \%$ DMSO alone. Thus, surprisingly, TAT-HMG supports testis determination in terms of Sertoli cell differentiation, although it is unable to rescue testis cord formation coordinately. Based on this finding, TAT-HMG was acting downstream of testis cord formation. It might be also possible that the pathway of cord formation separates from gene expression somewhere in the hierarchy of testis determination earlier during the gonadal development. Another possibility could be altered gene expression during the progress of testicular differentiation.

The results of real-time RT-PCR revealed that in XY gonads 1 day after treatment with TAT-HMG, Sry transcript levels were upregulated about 3 fold compared to untreated control or DMSO treatment. Sry upregulation is consistent with and can explain the delay in down regulation of SRY protein observed by SRY immunolabeling. In addition, Sox9 transcript levels slightly increased compared to the treatment with DMSO alone, but they were still significantly lower than the levels in the untreated control. On the other hand, Mis transcript levels reached the levels of untreated control 1 day after treatment with TAT-HMG, but this upregulation was not consistent with what we observed by immunolabeling of MIS, although MIS expression reaches the untreated control levels by the end of culture. One possibility is that, expression of genes downstream of Sox9 could be repressed temporarily but compensated by Sry up regulation immediately. Another possible explanation is that TAT-HMG bound to the Sry promoter and upregulated its transcription. However, this model cannot explain why the Sox9 transcript levels remained low despite the high Sry transcript levels. It might be possible that even very low levels of Sox 9 transcript is sufficient for Sertoli cell differentiation in $\mathrm{XY}$ gonads, as we could see that SOX9 expression levels in treated gonads did 
not differ remarkably from untreated control 1 day and 2 days after culture. An alternative explanation is that TAT-HMG competed with SRY in binding to the Sry target site and while keeping Sox9 transcription at low levels, promoted Sry transcription by a negative feedback mechanism.

\subsection{Prolonged SRY expression and delay in Sertoli cell differentiation}

In this study we observed that Sry downregulation in XY gonads was delayed after treatment with TAT-HMG, which was tightly associated with the delay in MIS expression. The delay in Sertoli cell differentiation can be attributed to the low levels of Sox9 transcript. Consistently, it has been reported that in mice lacking Sox9 activity in fetal gonads, Sry expression persists (Chaboissier et al., 2004; Barrionuevo et al., 2006). Before we examined the effect of DMSO on our organ culture we had assumed that testis cord disruption might be associated with the delay in SRY downregulation and MIS expression, which implies a delay in Sertoli cell differentiation. However, this delay cannot explain it any more.

\subsection{Association of Fgf9 and Wnt4 transcript levels with testicular differentiation in culture}

The antagonistic relationship between Fgf9 and Wnt4 in gonadal sex differentiation has been suggested; Fgf9 is upregulated in Sertoli cells and promotes testis cord organization, whereas Wnt4 is upregulated in XX gonads and suppresses testicular differentiation (Colvin et al., 2001; Schmahl et al., 2004). However, we did not find any significant differences in the transcript levels of either Fgf9 or Wnt4 in the XX or XY gonads within 3 days in culture. It is convincible that sexually dimorphic regulations of $F g f 9$ and $W n t 4$ are relatively late events and did not occur during the three days of culture in the gonads. Alternatively, gonadal differentiation in culture may not be parallel to that of in vivo. Nevertheless, our results indicated that Sertoli cell differentiation and testis cord 
organization in culture are not associated with transcript levels of either Fgf9 or Wnt4.

\subsection{Migration of mesonephric cells into developing gonad}

We consistently observed that the $X Y$ urogenital complexes treated with DMSO with or without TAT-HMG were smaller in size than untreated controls after culture for 3 days. Therefore, we considered the possibility that some cells died by treatment, preventing the proliferation of pre-Sertoli cells or migration of mesenchymal cells from adjacent mesonephros. Both events are known to play critical roles in the organization of testis cords. The TUNEL reaction preferentially labels DNA single strand breaks (nicks) generated during apoptosis. Apoptosis is programmed cell death, which can be identified by labeling free 3'-OH termini of DNA with an enzymatic reaction. The results of TUNEL indicated that, indeed, there was a massive cell death in the mesonephros of the urogenital complexes treated with DMSO. TAT-HMG treatment did not change this selective cell death. By contrast, TUNEL-positive cells were much fewer and not restricted to the mesonephric part of the urogenital complex in the untreated control. The selective cell death in the mesonephros can be attributed to the vulnerability of the mesonephros or resistance of the gonad to DMSO treatment. To distinguish these possibilities, we treated kidney and a piece of limb-bud with TAT-HMG dissolved in DMSO for 3 days (data not shown). We observed necrosis in the middle of both types of tissues but no concentrated TUNEL-positive cells in the periphery region. We concluded that DMSO treatment caused cell death preferentially in the mesonephros and TAT-HMG was unable to rescue mesonephric cells from death. This effect of DMSO is separate from that on the gene expression part of testis determining pathway, which could be rescued by the treatment with TAT-HMG or its resultant upregulation. Consequently the massive cell death and probably the loss of mesenchymal cells in the mesonephros decreased the migration of mesonephric cells into the gonad and is likely responsible for the absence of testis cord organization after treatment with DMSO. 


\subsection{Conclusions}

We found that $0.6 \%$ and $1.8 \%$ DMSO disturbed and completely blocked testicular differentiation, respectively. Unexpectedly, TAT-HMG did not suppress testicular differentiation; after treatment with TAT-HMG Sertoli cells differentiated, although testis cord formation was still absent. We concluded that, at least in culture, Sertoli cell differentiation is independent of testis cord formation. In addition, rescue of testicular differentiation by PGD2 suggested that $P g d 2$ could be located upstream of Sox9 in the pathway of testis determination. 


\section{References}

Achermann JC, Ito M, Ito M, Hindmarsh PC, Jameson JL. A mutation in the gene encoding steroidogenic factor- 1 causes XY sex reversal and adrenal failure in humans. Nat. Genet. 1999, 22:125-126.

Adams I, McLaren A. Sexually dimorphic development of mouse primordial germ cells: switching from oogenesis to spermatogenesis. Development, 2002, 129: $1155-1164$.

Albrecht KH, Eicher EM: Evidence that Sry is expressed in pre-Sertoli cells and Sertoli and granulosa cells have a common precursor. Dev. Biol. 2001, 240: 92 107.

Altincicek, B., Tenbaum, S. P., Dressel, U., Thormeyer, D., Renkawitz, R. and Baniahmad, A. Interaction of the corepressor Alien with DAX- 1 is abrogated by mutations of DAX-1 involved in adrenal hypoplasia congenita. J. Biol. Chem. 2000, 275: 7662-7667.

Aoyama S, Shibata K, Tokunaga S, Takase M, Matsui K, Nakamura M: Expression of Dmrt1 protein in developing and in sexreversed gonads of amphibians. Cytogenet. Genome Res. 2003, 101:295-301.

Bae, D. S., Schaefer, M. L., Partan, B. W. and Muglia, L. Characterization of the mouse DAX-1 gene reveals evolutionary conservation of a unique aminoterminal motif and widespread expression in mouse tissue. Endocrinology, 1996, 137: 3921-3927.

Bardoni B, Zanaria E, Guioli S, Floridia G, Worley KC, Tonini G, Ferrante E, Chiumello G, McCabe ERB, Fraccaro M, Zuffardi O, Camerino G. A dosage sensitive locus at chromosome $\mathrm{Xp} 21$ is involved in male to female sex reversal. Nature Genet. 1994, 7: 497-501.

Baron D, Cocquet J, Xia X, Fellous M, Guiguen Y, Veitia RA. An evolutionary and functional analysis of FoxL2 in rainbow trout gonad differentiation. J Mol Endocrinol. 2004, 33: 705-715. 
Baron D., Batista F., Chaffaux S., Cocquet J., Cotinot C., Cribiu E., De Baeree E., Guiguen Y., Jaubert F., Pailhouxd E., Pannetier M., Vaiman D., Bernard V.R., Fellous M.: "Foxl2 gene and the development of the ovary: a story about goat, mouse, fish and woman." Reprod. Nutr. Dev. 2005, 45: 377-382.

Barrionuevo F, Bagheri-Fam S, Klattig J, Kist R, Taketo MM, Englert C, Scherer G. Homozygous inactivation of Sox 9 causes complete XY sex reversal in mice. Biol. Reprod. 2006, 74: 195-201.

Beau, C., Rauch, M., Joulin, V., Jégou, B., Guerrier, D. GATA-1 is a potential repressor of anti-Müllerian hormone expression during the establishment of puberty in the mouse. Mol. Reprod. Dev. 2000, 56: 124-138.

Beau, C., Vivian, N., Münsterberg, A., Dresser, D.W., Lovell-Badge, R., Guerrier, D. In vivo analysis of the regulation of the anti-Müllerian hormone, as a marker of Sertoli cell differentiation during testicular development, reveals a multi-step process. Mol. Reprod. Dev. 2001, 59: 256-264.

Beaumont HM, Mandl AM. A quantitative study of primordial germ cells in the male rat. J. Embryol. Exp. Morphol. 1963, 11: 715-740.

Behringer RR, Cate RL, Froelick GJ, Palmiter RD, Brinster RL. Abnormal sexual development in transgenic mice chronically expressing Müllerian inhibiting substance. Nature, 1990, 345:167-170.

Behringer RR, Finegold MJ, Cate RL. Müllerian-inhibiting substance function during mammalian sexual development. Cell, 1994, 79: 415-425.

Bendel-Stenzel M, Anderson R, Heasman J, Wylie C. The origin and migration of primordial germ cells in the mouse. Semin Cell Dev Biol, 1998, 9: 393-400. Bernard, P. and Harley V. R. Wnt4 action in gonadal development and sex determination. The Intl. J. Biochem. \& Cell Biol. 2007, 39: 31-43.

Berta P, Hawkins JR, Sinclair AH, Taylor A, Griffiths BL, Goodfellow PN, Fellous M. Genetic evidence equating $S R Y$ and the male sex determining gene. Nature, 1990, 348: 448-450.

Beverdam A, Koopman P. Expression profiling of purified mouse gonadal somatic cells during the critical time window of sex determination revearls novel candidate genes for human dysgenesis syndromes. Hum. Mol. Genet., 2006, 3 : 
417-431.

Beye M, Hasselmann M, Fondrk MK, Page RE, Omholt SW: The Gene $c s d$ Is the Primary Signal for Sexual Development in the Honeybee and Encodes an SR-Type Protein. Cell 2003, 114:419-429.

Birk OS, Casiano DE, Wassif CA, et al. The LIM homeobox gene $L h x 9$ is essential for mouse gonad formation. Nature, 2000, 403: 909-913.

Bishop-Calame S. Further research concerning the role of the Wolffian duct in the differentiation of the mesonephros of the chick embryo. J Embryol Exp Morphol 14: 239-245, 1965.

Boie Y, Sawyer N, Slipetz DM, Metters KM, Abramovitz M. Molecular cloning and characterization of the human prostanoid DP receptor. J. Biol. Chem. 1995, 270: $18910-18916$.

Borum K. Oogenesis in the mouse. A study of the meiotic prophase. Exp. Cell. Res. 1961, 24: 495-507.

Bouin P, Ancel P. Recherches sur les cellules interstitielles du testicule des mammiferes. Arch de Zool. Exp. Gen. 1903, 1: 437-523.

Bouma GJ, Albrecht KH, Washburn LL, Recknagel AK, Churchill GA, Eicher EM. Gonadal sex reversal in mutant Dax1 XY mice: a failure to upregulate Sox9 in pre-Sertoli cells. Development , 2005,132: 3045-3054.

Bouma GJ, Affourtit JP, Bult CJ, Eicher EM. Transcriptional profiling of mouse pre-granulosa and Sertoli cells isolated from early-differentiated fetal gonads.

Gene exp. Patterns, 2007, 7: 113-123.

Bowles J, Berkman J, Cooper L, Koopman P. Sry requires a CAG repeat domain for male sex determination in Mus musculus. Nature Genet. 1999, 22: 405-408.

Bowles J, Bullejos M, Koopman P. Screening for novel mammalian sexdetermining genes using expression cloning and microarray approaches. Australian Biochemist, 2000, 31: 4-6.

Bowles J, Knight D, Smith C, Wilhelm D, Richman J, Mamiya S, Yashiro K, Chawengsaksophak K, Wilson MJ, Rossant J, Hamada H, Koopman P. Retinoid signaling determines germ cell fate in mice. Science, 2006, 312: 596-600.

Brennan J, Capel B. One tissue, two fates: molecular genetic events that 
underlie testis versus ovary development. Nat. Rev. Genet. 2004, 5: 509-521. Brennan J, Tilmann C, Capel B. PDGFR-alpha mediates testis cord organization and fetal Leydig cell development in the XY gonad. Genes Dev 17: 800-810, 2003.

Breyer MD, Breyer RM. G protein-coupled prostanoid receptors and the kidney. Annu. Rev. Physiol. 2001, 63: 579-605.

Buehr M, Gu S, McLaren A. Mesonephric contribution to testis differentiation in the fetal mouse. Development, 1993, 117: 273-281.

Bullejos M, Bowles J, Koopman P. Extensive vascularization of developing mouse ovaries revealed by caveolin-1 expression. Dev. Dyn. 2002, 225: 95-99. Burgoyne PS, Buehr M, McLaren A. XY follicle cells in ovaries of XX $\times \mathrm{XY}$ female mouse chimaeras. Development, 1988, 104: 683-688.

Burgoyne PS. Role of mammalian Y chromosome in sex determination. Philos. Trans. R. Soc. Lond. B. Biol. Sci. 1988, 322:63-72.

Byskov AG, Fenger M, Westergaard L, Andersen CY. Forskolin and the meiosis inducing substance synergistically initiate meiosis in fetal male germ cells. Mol. Reprod. Dev. 1993, 34: 47-52.

Byskov AG, Saxen L. Induction of meiosis in fetal mouse testis in vitro. Dev Biol, 1976, 52: 193-200.

Byskov AG. Differentiation of Mammalian Embryonic Gonad. Physiological Reviews 1986, Vol. 66, No. 1, January.

Byskov AG. The anatomy and ultrastructure of the rete system in the fetal mouse ovary. Biol. Reprod. 1978, 19: 720-735.

Byskov, A. G., C. Yding Andersen, and L. Westergaard. Dependence of the onset of meiosis on the internal organization of the gonad. In: Current Problems in Germ Cell Differentiation, edited by A. McLaren and C. C. Wiley. Cambridge, UK: Cambridge Univ. Press, 1983, 215- 224. Bysokv, A. G., N. E. Skakkebazk, G. Stafanger, H. Peters. Influence of ovarian surface epithelium and rete ovarian follicle formation. J. Anat, 1977.123: 77-86 Capel B, Albrecht KH, Washburn LL, Eicher EM. Migration of mesonephric 
cells into the mammalian gonad depends on Sry. Mech. Dev. 1999, 84: 127-131. Capel B. The battle of the sexes. Mech. Dev. 2000, 92: 89-103.

Caricasole, A., Duarte, A., Larsson, S.H., Hastie, N.D., Little, M., Holmes, G., Todorov, I., and Ward, A. RNA binding by the Wilms tumor suppressor zinc finger proteins. Proc. Natl. Acad. Sci. USA 1996, 93: 7562-7566.

Carmi I, Kopczynski JB, Meyer BJ: The nuclear hormone receptor SEX-1 is an X-chromosome signal that determines nematode sex. Nature 1998, 396:168-173. Cederroth C. R., Pitetti J., Papaioannou M. D., Nef S. Genetic programs that regulate testicular and ovarian development. Mole. Cell. Endocrinol. 2007, 265266: 3-9.

Chaboissier MC, Kobayashi A, Vidal VIP, Lutzkendorf S, van de Kant HJG, Wegner M, de Rooij DG, Behringer RR, Schedl A. Functional analysis of Sox8 and Sox9 during sex determination in the mouse. Development 2004, 131: 1891-1901.

Chan, S.T.H. Natural sex reversal in vertebrates. Philos. Trans. R. Soc. Lond. B Biol. Sci.1970, 259: 59-71.

Charlesworth B: Sex Determination in the Honeybee. Cell 2003, 114:397-398. Chauhan A, Tikoo A, Kapur AK, Singh M. The taming of the cell penetrating domain of the HIV Tat: myths and realities. J. Control Release. 2007, 117: 14816.

Clement TM, Anyway MD, Uzumcu M, Skinner MK. Regulation of gonadal transcriptome during sex determination and testis morphogenesis: comparative candidate genes. Reproduction, 2007, 134: 455-472.

Clinton M, Haines LC: An overview of factors influencing sex determination and gonadal development in birds. Cell. Mol. Life Sci. 1999, 55:876-886. Clipsham, R. and McCabe, E. R. DAX1 and its network partners: exploring complexity in development. Mol. Genet. Metab. 2003, 80: 81-120.

Cohen-Haguenauer, O., Picard, J.Y., Mattei, M.G., Serero, S., Nguyen, V.C., de Tand, M.F., Guerrier, D., Hors-Cayla, M.C., Josso, N., Frézal, J. Mapping of the gene for anti-Müllerian hormone to the short arm of human chromosome 19. Cytogenet. Cell Genet. 1987, 44: 2-6. 
Colvin JS,Green RP, Schmahl J, Capel B, Ornitz DM. Male to female sex reversal in mice lacking fibroblast growth factor 9. Cell, 2001; 104: 875-889. Cory AT, Boyer A, Pilon N, Lussier JG, Silverside WD. Presumptive pre-Sertoli cells express genes involved in cell proliferation and cell signaling during a critical window in early testis differentiation. Mol. Reprod. Dev. 2007, 74: 14911504.

Cotinot, C., Pailhoux E., Jaubert F., Fellous M. Molecular genetics of sex determination. Seminars in Reproductive Medicine, 2002, 20: 157-167. Crawford, P. A., Dorn, C., Sadovsky, Y. and Milbrandt, J. Nuclear receptor DAX-1 recruits nuclear receptor corepressor N-CoR to steroidogenic factor 1 . Mol. Cell. Biol. 1998, 18: 2949-2956.

Crisponi L, Deiana M, Loi A, Chiappe F, Uda M, Amati P, Bisceglia L, Zelante L, Nagaraja R, Porcu S, Ristaldi MS, Marzella R, Rocchi M, Nicolino M, Lienhardt-Roussie A, Nivelon A, Verloes A, Schlessinger D, Gasparini P, Bonneau D, Cao A, Pilia G. The putative forkhead transcription factor FOXL2 is mutated in blepharophimosis /ptosis /epicanthus inversus syndrome. Nature Genet. 2001, 27: 159-166.

Davies, R.C., Calvio, C., Bratt, E., Larsson, S.H., Lamond, A.I., and Hastie, N.D. WT1 interacts with the splicing factor U2AF65 in an isoform- dependent manner and can be incorporated into spliceosomes. Genes Dev. 1998, 12: $3217-$ 3225 .

De Loof A, Huybrechts R: "Insects do not have sex hormones": a myth? Gen Comp Endocrinol 1998, 111:245-260.

de Santa Barbara, P., Bonneaud, N., Boizet, B., Desclozeaux, M., Moniot, B., Sudbeck, P., Scherer, G., Poulat, F., Berta, P. Direct interaction of SRY-related protein SOX9 and steroidogenic factor 1 regulates transcription of the human anti-Müllerian hormone gene. Mol. Cell. Biol. 1998, 18, 6653-6665.

Desclozeaux M, Poulat F, de Santa Barbara P, Capony JP, Turowski P, Jay P, Mejean C, Moniot B, Boizet B, Berta P. Phosphorylation of an N-terminal motif enhances DNA-binding activity of the human SRY protein. J. Biol. Chem. 1998, 273: 7988-7995. 
Dietz GP, Bähr M. Delivery of bioactive molecules into the cell: the Trojan horse approach. Mol. Cell Neurosci. 2004, 27: 85-131.

Dolci S, De Felici M. A study of meiosis in chimeric mouse fetal gonads.

Development, 1990, 109: 37-40.

Dresser, D.W., Hacker, A., Lovell, B., Guerrier, D. The genes for a spliceosome protein (SAP62) and the anti-Müllerian hormone (AMH) are contiguous. Hum. Mol. Genet. 1995, 4: 1613-1618.

Dubin RA, Ostrer H. Sry is a transcriptional activator. Mol. Endocrinol. 1994, 8: $1182-1192$.

Eicher EM, Washburn LL: Genetic control of primary sex determination in mice. Annu. Rev. Genet. 1986, 20: 327-360.

Eicher, E. M., Shown, E. P. and Washburn, L. L. Sex reversal in C57BL/6JYPOS mice corrected by a Sry transgene. Philos. Trans. R. Soc. London Ser. B, 1995, 350: 263-269.

Eicher, E.M., Washburn, L.L., Schork, N.J., Lee, B.K., Shown, E.P., Xu, X., Dredge, R.D., Pringle, M.J., Page, D.C.. Sex-determining genes on mouse autosomes identified by linkage analysis of C57BL/6J-YPOS sex reversal. Nat. Genet. 1996, 14 (2), 206-209.

Ellegren $\mathrm{H}$ : Hens, cocks and avian sex determination. A quest for genes on $\mathrm{Z}$ or W? Embo. Reports, 2001, 2:192-196

Englert, C., Vidal, M., Maheswaran, S., Ge, Y., Ezzell, R.M., Issel bacher, K.J., and Haber, D.A. (). Truncated WT1 mutants alter the subnuclear localization of the wild-type protein. Proc. Natl. Acad.Sci. USA, 1995, 92: 11960-11964.

Fawcett D. W. Ultrastructure and function of the Sertoli cell. In: Handbook of Physiology Male Reproductive system, edited by R. 0. Greep and E. B. Astwood. Washington, DC: Am. Physiol. Sot., 1975, sect. 7, vol. V, chapt. D. 21-55.

Fawell, S. et al. Tat-mediated delivery of heterologous proteins into cells. Proc. Natl. Acad. Sci USA, 1994, 91: 664-668.

Ferguson MW: Temperature of egg incubation determines sex in Alligator mississippiensis. Nature 1982, 296:850-853. 
Ferrari S, Harley VR, Pontiggia A, Goodfellow PN, Lovell-Badge R, Bianchi ME. SRY, like HMG1, recognizes sharp angles in DNA. EMBO J. 1992, 11: 4497-4506.

Ford CE, Evans EP, Gardner RL.: Marker chromosome analysis of two mouse chimaeras. J. Embryol. Exp. Morphol. 1975, 33: 447-457.

Forwood J. K., Harley V., and Jans D. A. "The C-terminal Nuclear Localization Signal of the Sex-determining Region Y (SRY) High Mobility Group Domain Mediates Nuclear Import through Importin- $\beta 1$. The J. of Biol. Chem. 2001, 276: 46575-46582.

Foster JW, Dominguez-Steglich MA, Guioli S, Kowk G, Weller PA, Stevanovic M, Weissenbach J, Mansour S, Young ID, Goodfellow PN, Brook JD, Schafer AJ. Campomelic dysplasia and autosomal sex reversal caused by mutations in an SRY-related gene. Nature, 1994, 372: 525-530.

Frankel, A.D. \& Pabo, C.O. Cellular uptake of the tat protein from human immunodeficiency virus. Cell, 1988, 55: 1189-1193.

Fujiwara Y, Komiya T, Kawabata H, Sato M, Fujimoto H, Furusawa M, Noce T: Isolation of a DEAD-family protein gene that encodes a murine homolog of Drosophila vasa and its specific expression in germ cell lineage. Proc. Natl. Acad. Sci. USA. 1994, 91:12258-12262.

Gao, F., S. Maiti, N. Alam, Z. Zhang, J. M. Deng, R. R. Behringer, C. Lecureuil, F. Guillou, and V. Huff. The Wilms tumor gene, Wt1, is required for Sox9 expression and maintenance of tubular architecture in the developing testis. Proc. Natl. Acad. Sci. USA. 2006, 103: 11987-11992.

Goldfarb, M. Signaling by fibroblast growth factors: the inside story. Sci. STKE, 2001,106, PE37.

Gondos, B. Testicular development In: TIte 2" edited by A. D. Johnson and W. R. Gomes. New York Academic, 1977, 4: 1-37.

Govoroun M, Pannetier M, Pailhoux E, Cocquet J, Brillard JP, Couty I, Batellier $\mathrm{F}$, Cotinot C. Isolation of chicken homolog of foxl2 gene and comparison of its expression patterns with those of aromatase during ovarian development. Dev. Dyn. 2004, 231: 859-870. 
Graves JAM, Shetty S: Sex from $\mathrm{W}$ to $\mathrm{Z}$ : evolution of vertebrate sex chromosomes and sex determining genes. J Exp Zool 2001, 290:449-462.

Green, M. \& Loewenstein, P.M. Autonomous functional domains of chemically synthesized human immunodeficiency virus tat trans-activator protein. Cell, 1988, 55: 1179-1188.

Gropp, A., Ohno S. Presence of a common embryonic blastema for ovarian and testicular parenchymal (follicular, interstitial and tubular) cells in cattle.

Bostaurua Z Zellfrosch Milcrosk. Anatomy, 1966, 74: 505-523.

Gubbay J, Koopman P, Collignon J, Burgoyne P, Lovell-Badge R. Normal structure and expression of Zfy genes in XY female mice mutant in Tdy.

Development, 1990, 109: 647-653.

Gubbay J, Vivian N, Economou A, Jackson D, Goodfellow P, Lovell-Badge R. Inverted repeat structure of the Sry locus in mice. Proc. Natl. Acad. Sci. USA, 1992, 89: 7953-7957.

Hacker A, Capel B, Goodfellow P, Lovell-Badge R. Expression of Sry, the mouse sex determining gene. Development, 1995, 121: 1603-1614.

Hageman RM, Cameron FJ, SinclairAH. Mutation analysis of the SOX9 gene in a patient with campomelic dysplasia. Hum. Mutat. Suppl. 1998, 1: S112-S113. Hanley N, Hagan D, Clement-Jones M, Ball S, Strachan T, Salas-Corte's L, McElreavey K, Lindsay S, Robson S, Bullen P, Ostrer H, Wilson D. SRY, $S O X 9$, and $D A X 1$ expression patterns during human sex determination and gonadal development. Mech. Dev, 2000, 91: 403-407.

Haqq, C.M., King, C.Y., Ukiyama, E., Falsafi, S., Haqq, T.N., Donahoe, P.K., Weiss, M.A. Molecular basis of mammalian sexual determination: activation of Müllerian inhibiting substance gene expression by SRY. Science, 1994, 266: 1494-1500.

Haqq, C. M., King, C. Y., Donahoe, P. K. and Weiss, M. A. SRY recognizes conserved DNA sites in sex-specific promoters. Proc. Natn. Acad. Sci. USA, 1993: 90, 1097-1101.

Hardy MP, Nonneman D, Ganjam VK, Zirkin BR. Hormonal control of Leydig cell differentiation and mature function. In: Understanding Male Fertility: Basic 
and Clinical Approaches, edited by Whitcomb R and Zirkin BR. New York:

Raven, 1993, p. 125-142.

Harley V.R., Clarkson M. J., Argentaro A. The Molecular Action and

Regulation of the Testis-Determining Factors, SRY (Sex-Determining Region on the Y Chromosome) and SOX9 [SRY-Related High-Mobility Group (HMG) Box 9]. Endocrine Reviews, 2003, 24: 466-487.

Harley VR, Jackson DI, Hextall PJ, Hawkins JR, Berkovitz GD, Sockanathan S, Lovell-Badge R, Goodfellow PN. DNA binding activity of recombinant SRY from normal males and XY females. Science, 1992, 255: 453-456.

Harley VR, Lovell-Badge R, Goodfellow PN, Hextall PJ. The HMG box of SRY is a calmodulin binding domain. FEBS Lett. 1996, 391: 24-28.

Harvey P, Slatkin M: Some like it hot: temperature-determined sex. Nature 1982, 296:807-808.

Hawkins, J. R. Mutational analysis of $S R Y$ in XY females. Human Mutation, 1993, 2: 347-350.

Hilscher B, Hilscher W, Bulthoff-Ohnolz B, Kramer U, Birke A, Pelzer H, Gauss G. Kinetics of gametogenesis. I. Comparative histological and autoradiographic studies of oocytes and transitional prospermatogonia during oogenesis and prespermatogenesis. Cell Tissue Res, 1974, 154: 443-470.

Hirai H, Tanaka K, Yoshie O, Ogawa K, Kenmotsu K, Takamori Y, Ichimasa M, Sugamura K, Nakamura M, Takano S, Nagata K. Prostaglandin D2 selectively induces chemotaxis in T helper type 2 cells, eosinophils, and basophils via seven-transmembrane receptor CRTH2. J. Exp. Med. 2001, 193: 255-261. Hofsten J, Per-Erik O: Zebra-fish sex determination and differentiation: Involvement of FTZ-F1 genes. Reprod. Biol. Endocrinol. 2005, 3:63. Hollyday,M., McMahon, J. A.,\&McMahon, A. P. Wnt expression patterns in chick embryo nervous system. Mech. Dev. 1995, 52: 9-25.

Holter E, Kotaja N, Makela S, Strauss L, Kietz S, Janne OA, Gustafsson JA, Palvimo JJ, Treuter E. Inhibition of androgen receptor (AR) function by the reproductive orphan nuclear receptor DAX-1. Mol. Endocrinol. 2002, 16: 515528 . 
Hunt, S.E., Mittwoch, U. Y-chromosomal and other factors in the development of testis size in mice. Genet. Res. 1987, 50: 205-211.

Ikeda, Y., Shen, W. H., Ingraham, H. A. and Parker, K. L. Developmental expression of mouse steroidogenic factor-1, an essential regulator of the steroid hydroxylases. Mol. Endocrinol. 1994, 8: 654-662.

Ikeda, Y., Swain, A., Weber, T. J., Hentges, K. E., Zanaria, E., Lalli, E., Tamai, K. T., Sassone-Corsi, P., Lovell-Badge, R., Camerino, G. et al. Steroidogenic factor 1 and Dax-1 colocalize in multiple cell lineages: potential links in endocrine development. Mol. Endocrinol. 1996, 10: 1261-1272.

Ikeda, Y., Takeda, Y., Shikayama, T., Mukai, T., Hisano, S. and Morohashi, K. I. Comparative localization of Dax-1 and Ad4BP/SF-1 during development of the hypothalamic-pituitary-gonadal axis suggests their closely related and distinct functions. Dev. Dyn. 2001, 220: 363-376.

Ito M, Yu R, Jameson JL. DAX-1 inhibits SF-1-mediated transactivation via a carboxy-terminal domain that is deleted in adrenal hypoplasia congenita. Mol, Cell. Biol. 1997, 17: 1476-1483.

Jager RJ, Anvret M, Hall K, Scherer G. A human XY female with a frame shift mutation in the candidate testis-determining gene SRY. Nature, 1990, 348: 452454.

Jeays-Ward K, Hoyle C, Brennan J, Dandonneau M, Alldus G, Capel B, Swain A. Endothelial and steroidogenic cell migration are regulated by WNT4 in the developing mammalian gonad. Development, 2003, 130: 3663-3670.

Jeske YWA, Bowles J, Greenfield A, Koopman P. Expression of a linear Sry transcript in the mouse genital ridge. Nat .Genet. 1995, 10:480-482.

Johnson J, Bagley J, Skaznik-Wikiel M, Lee HJ, Adams GB, Niikura Y, Tschudy KS, Tilly JC, Cortes ML, Forkert R, Spitzer T, Iacomini J, Scadden DT, Tilly JL. Oocyte generation in adult mammalian ovaries by putative germ cells in bone marrow and peripheral blood. Cell, 2005, 122: 303-315. Johnson J, Canning J, Kaneko T, Pru JK, Tilly JL. Germline stem cells and follicular renewal in the postnatal mammalian ovary. Nature, 2004, 428: 145150. 
Jordan, B.K., Shen, J.H., Olaso, R., Ingraham, H.A., Vilain, E. Wnt4 overexpression disrupts normal testicular vasculature and inhibits testosterone synthesis by repressing steroidogenic factor $1 /$ beta-catenin synergy. Proc. Natl. Acad. Sci. USA, 2003, 100: 10866- 10871.

Jorgensen JS, Gao L. Irx3 is differentially up-regulated in female gonads during sex determination. Gene. Expr. Patterns. 2005, 5: 756-762,

Jost A, Vigier B, Prepin J, Perchellet JP. Studies on sex differentiation in mammals. Recent Prog. Horm. Res. 1973, 29:1-41.

Jost, A. Recherches sur la diff renciation sexuelle de I'embryon de lapin. Arch. Anat. Microsc. Morph. Exp. 1947: 36, 271-315.

Karl J, Capel B. Sertoli cells of the mouse testis originate from the coelomic epithelium. Dev Biol, 1998, 203: 323-333.

Karl J, Capel B. Three-dimensional structure of the developing mouse genital ridge. Philos Trans R Soc Lond, 1995, 350: 235-242.

Katoh-Fukui Y, Tsuchiya R, Shiroishi T, et al. Male-to female sex reversal in M33 mutant mice. Nature, 1998, 393: 688-692.

Kennedy D, Ramsdale T, Mattick J, Little M. An RNA recognition motif in Wilms' tumour protein (WT1) revealed by structural modelling. Nat. Genet. 1996, 12: 329-331.

Kent, J., Coriat, A.M., Sharpe, P.T., Hastie, N.D., and van Heyningen, V. The evolution of WT1 sequence and expression pattern in the vertebrates. Oncogene 1995, 11: 1781-1792.

Kent, J., Wheatley, S.C., Andrews, J.E., Sinclair, A.H., Koopman, P. A malespecific role for SOX9 in vertebrate sex determination. Development , 1996,122: 2813-2822.

Keyes LN, Cline TW, Schedi P: The primary sex determination signal of Drosophila acts on the level of transcription. Cell 1992, 68:933-943.

Kim Y, Kobayashi A, Sekido R, DiNapoli L, Brennan J, Chaboissier MC, Poulat F, Behringer R, Lovell-Badge R, Capel B: Fgf9 and Wnt4 act as antagonistic signals to regulate mammalian sex determination. Plosbiology, 2006, 4: 10001010. 
Kim, J., Prawitt, D., Bardeesy, N., Torban, E., Vicaner, C., Goodyer, P., Zabel, B., and Pelletier, J. The Wilms' tumor suppressor gene (wt1) product regulates Dax-1 gene expression during gonadal differentiation. Mol. Cell. Biol. 1999, 19: 2289-2299.

Kim, Y., \& Capel ,B. "Balancing the Bipotential Gonad Between Alternative Organ Fates: A New Perspective on an Old Problem." DEVELOPMENTAL DYNAMICS 2006, 235: 2292-2300.

King, C.-Y., Weiss, M. A. The SRY high-mobility-group box recognizes DNA by partial intercalation in the minor groove: A topological mechanism of sequence specificity. Proc. Natn. Acad. Sci. USA 1993, 90: 11990-11994. Kispert, A., Vainio, S., \& McMahon, A. P. Wnt-4 is a mesenchymal signal for epithelial transformation of metanephric mesenchyme in the developing kidney. Development, 1998, 125: 4225-4234.

Klattig, J. r., Sierig R., Kruspe D., Besenbeck B., and Englert C. Wilms' Tumor Protein Wt1 Is an Activator of the Anti-Mu"llerian Hormone Receptor Gene Amhr2. MCB, 2007, 27: 4355-4364

Konishi I, Fujii S, Okamura H, Parmley T, Mori T. Development of interstitial cells and ovigerous cords in the human fetal ovary: an ultrastructural study. J. Anat. 1986, 148: 121-135.

Koopman P, Gubbay J, Vivian N, Goodfellow P, Lovell Badge R. Male development of chromosomally female mice transgenic for Sry. Nature 1991;351:117-121

Koopman P, Munsterberg A, Capel B, Vivian N, Lovell-Badge R. Expression of a candidate sex-determining gene during mouse testis differentiation. Nature, 1990, 348: 450-452.

Koubova J, Menke DB, Zhou Q, Capel B, Griswold MD, Page DC. Retinoic acid regulates sex-specific timing of meiotic initiation in mice. Proc. Natl. Acad. Sci. USA, 2006, 103: 2474-2479.

Kreidberg JA, Sariola H, Loring JM, et al. WTI is required for early kidney development. Cell, 1993, 74: 679-691.

Krovel A, Olsen L: Sexual dimorphic expression pattern of a splice variant of 
zebrafish vasa during gonadal development. Dev. Biol. 2004, 271:190-197. Krylova, I. N., Sablin, E. P., Moore, J., Xu, R. X., Waitt, G. M., MacKay, J. A., Juzumiene, D., Bynum, J. M., Madauss, K., Montana, V. et al. Structural analyses reveal phosphatidyl inositols as ligands for the NR5 orphan receptors SF-1 and LRH-1. Cell, 2005: 120, 3433-3455.

Kuwabara PE, Kimble J: Molecular genetics of sex determination in C.elegans. TIG 1992, 8:164-168.

Kuwabara PE, Perry MD: It ain't over till it's ova: germline sex determination in C.elegans. BioEssays 2001, 23:596-604.

Kwok C, Weller PA, Guioli S, Foster JW, Mansour S, Zuffardi O, Punnett HH, Dominguez-Steglich MA, Brook JD, Young ID, Goodfellow PN, Schafer AJ. Mutations in SOX9, the gene responsible for Campomelic dysplasia and autosomal sex reversal. Am. J. Hum. Genet. 1995, 57:1028-1036. Ladomery, M.R., Slight, J., Mc, G.S., and Hastie, N.D. Presence of WT1, the Wilm's tumor suppressor gene product, in nuclear poly $(\mathrm{A})(+)$ ribonucleoprotein. J. Biol. Chem. 1999, 274: 36520-36526.

Laity, J.H., Dyson, H.J., and Wright, P.E. Molecular basis for modulation of biological function by alternate splicing of the Wilms' tumor suppressor protein. Proc. Natl. Acad. Sci. USA, 2000, 97: 11932- 11935.

Lalli E, Ohe K, Latorre E, Bianchi ME, Sassone-Corsi P: Sexy splicing: regulatory interplays governing sex determination from Drosophila to mammals. J Cell Sci 2003, 116:441-445.

Lalli, E., Melner, M. H., Stocco, D. M. and Sassone-Corsi, P. DAX- 1 blocks steroid production at multiple levels. Endocrinology, 1998, 139, 4237- 4243. Lalli, E., Ohe, K., Hindelang, C. and Sassone-Corsi, P. Orphan receptor DAX-1 is a shuttling RNA binding protein associated with polyribosomes via mRNA. Mol. Cell. Biol. 2000, 20: 4910-4921.

Larsson, S. H., Charlieu, J.-P., Miyagawa, K., Engelkamp, D., Rassoulzadegan, M., Ross, A., Cuzin, F., van Heyningen, V. and Hastie, N. D. Subnuclear localization of WT1 in splicing or transcription factor domains is regulated by alternative splicing. Cell, 1995: 81, 391-401. 
Lawson KA, Hage WJ. Clonal analysis of the origin of primordial germ cells in the mouse. Ciba Found Symp. 1994, 182: 68-91.

Lee, S.B., Huang, K., Palmer, R., Truong, V.B., Herzlinger, D., Kol quist, K.A., Wong, J., Paulding, C., Yoon, S.K., Gerald, W. The Wilms tumor suppressor WT1 encodes a transcriptional activator of amphiregulin. Cell 1999, 98: 663673.

Li Y, Yue L, Taketo T, Lau YF. Protein transduction as a strategy for evaluating important factors in mammalian sex determination and differentiation.

Cytogenet. Genome Res. 2003, 101: 237-241.

Li, Y., Oh H. J., Lau Y-F C. "The poly(ADP-ribose) polymerase 1 interacts with Sry and modulates its biological functions. Mol. and Cell. Endocrinol. 2006, 257-258: 35-46.

Lodish H., B. A., Ziprusky S.L, Marsudaria P., Baltimore D., Darnell J.

Molecular biology of the cell, W.H. Freeman and Company, 2001.

Ludbrook LM, Harley VR. Sex determination: a "window" of DAX1 activity. Trends. Endocrinol. Metab. 2004, 15: 116-121.

Luo X, Ikeda Y, Parker KL. A cell-specific nuclear receptor is essential for adrenal and gonadal development and sexual differentiation. Cell, 1994, 77: 481-490.

Luo, X., Ikeda, Y. and Parker, K. L. A cell-specific nuclear receptor is essential for adrenal and gonadal development and sexual differentiation. Cell, 1994, 77; 481-490.

Magre, S., and A. Jost. The initial phases of testicular organogenesis in the rat. An electron microscopy study. Arch. Anat. Micros. Morphol. 1980, 69: 297-318. Maldonado L, Piedra A, Mendoza N, Valencia A, Martúneza A, Larios H: Expression profiles of Dax1, Dmrt1, and Sox9 during temperature sex determination in gonads of the sea turtle Lepidochelys olivacea. General and Comparative Endocrinology 2002, 129:20-26.

Malki S, Nef S, Notarnicola C, Thevenet L, Gasca S, Mejean C, Berta P, Poulat F, Boizet-Bonhoure B. Prostaglandin D2 induces nuclear import of the sexdetermining factor SOX9 via its cAMPPKA phosphorylation. EMBO. J. 2005, 
24: 1798-1809.

Manolakou P., L. G., Angelopoulou R.: Molecular patterns of sex determination in the animal kingdom: a comparative study of the biology of reproduction.

Reproductive Biology and Endocrinology, 2006, 4: 1477-7827.

Martineau J, Nordqvist K, Tilmann C, Lovell-Badge R, Capel B. Male-specific cell migration into the developing gonad. Curr. Biol. 1997; 7: 958-968

Matsuda M: Sex determination in the teleost medaka, Oryzias latipes. Annu. Rev. Genet. 2005, 39:293-307.

Matsuoka T, Hirata M, Tanaka H, Takahashi Y, Murata T, Kabashima K, Sugimoto Y, Kobayashi T, Ushikubi F, Aze Y, Eguchi N, Urade Y, Yoshida N, Kimura K, Mizoguchi A, Honda Y, Nagai H, Narumiya S. Prostaglandin D2 as a mediator of allergic asthma. Science, 2000, 287: 2013-2017.

McCabe, E. R. B. Adrenal hypoplasias and aplasias. In The Metabolic And Molecular Bases Of Inherited Disease, 2001: 4263-4274. New York: McGrawHill.

McDowall S, Argentaro A, Ranganathan S, Weller P, Mertin S, Mansour S, Tolmie J, Harley V. Functional and structural studies of wild type SOX9 and mutations causing campomelic dysplasia. J. Biol. Chem. 1999, 274: 2402324030

McElreavey K, Vilain E, Herskowitz I, Fellous M. A regulatory cascade hypothesis for mammalian sex determination: SRY represses a negative regulator of male development. Proc. Nat1. Acad. Sci. USA. 1993, 90: 33683372.

McLaren A, Simpson E, Tomonari K, Chandler P, Hogg H. Male sexual differentiation in mice lacking H-Y antigen. Nature, 1984, 312: 552-555. McLaren A. Development of the mammalian gonad: the fate of the supporting cell lineage. Bioessays, 1991, 13: 151-156.

McLaren A. Germ and somatic cell lineages in the developing gonad. Mol Cell Endocrinol, 2000; 163:3-9.

McLaren A., Southee D. Entry of mouse embryonic germ cells into meiosis. 
Dev Biol, 1997, 187: 107-113.

McLaren A: Germ cells and germ cell sex. Philos. Trans. R. Soc. Lond. B. Biol. Sci 1995, 350:229-233.

Meeks, J. J., Crawford, S. E., Russell, T. A., Morohashi, K., Weiss, J. and Jameson, J. L. Daxl regulates testis cord organization during gonadal differentiation. Development, 2003a, 130: 1029-1036.

Meeks, J. J., Weiss, J. and Jameson, J. L. Daxl is required for testis determination. Nat. Genet. 2003b, 34: 32-33.

Menke, A.L., van der Eb, A.J., and Jochemsen, A.G. The Wilms' tumor 1 gene: oncogene or tumor suppressor gene? Int. Rev. Cytol. 1998, 181: 151-212. Merchant, H. Rat gonadal and ovarian organogenesis with and without germ cells. An ultrastructural study. Lkv. Bid.1975, 44: 1-21.

Merchant-Larios H, Moreno-Mendoza N, Buehr M. The role of the mesonephros in cell differentiation and morphogenesis of the mouse fetal testis. Int J Dev Biol, 1993, 37: 407-415.

Messinger, S. M., Albertini D. F. Centrosome and microtubule dynamics during meiotic progression in the mouse oocyte. J. cell Sci. 1991, 100: 289-298.

Meyer BJ: Sex in the worm; counting and compensating X chromosome dose. TIG 2000, 16:247-253.

Meyer J, Sudbeck P, Held M, Wagner T, Schmitz ML, Bricarelli FD, Eggermont E, Friedrich U, Haas OA, Kobelt A, Leroy JG, Van Maldergem L, Michel E, Mitulla B, Pfeiffer RA, Schinzel A, Schmidt H, Scherer G. Mutational analysis of the SOX9 gene in campomelic dysplasia and autosomal sex reversal: lack of genotype/phenotype correlations. Hum. Mol. Genet. 1997, 6: 91-98.

Miles, C., Elgar, G., Coles, E., Kleinjan, D.J., van Heyningen, V., and Hastie, N. Complete sequencing of the Fugu WAGR region from WT1 to PAX6: dramatic compaction and conservation of synteny with human chromosome 11p13. Proc.

Natl. Acad. Sci. USA 1998, 95: 13068-13072.

Mintz, B. Continuity of the female germ cell line from embryo to adult. Arch. Anat. Micros. Morphol. 1959, 48: 155-172. 
Mittwoch, U. Do genes determine sex? Nature, 1969, 221: 446-448.

Mittwoch, U. Sex differentiation in mammals and tempo of growth: probabilities vs. switches. J. Theor. Biol. 1989, 137: 445-455.

Mittwoch, U., Buehr, M. Gonadal growth in embryos of sex reversed mice.

Differentiation, 1973, 1: 291-224.

Miyamoto N, Yoshida M, Kuratani S, Matsuo I, Aizawa S. Defects of urogenital development in mice lacking Emx2. Development, 1997, 124: 16531664.

Monneret G, Gravel S, Diamond M, Rokach J, Powell WS Prostaglandin D2 is a potent chemoattractant for human eosinophils that acts via a novel DP receptor. Blood, 2001, 98: 1942-1948.

Morais da Silva, S., Hacker, A., Harley, V., Goodfellow, P., Swain, A., LovellBadge, R. Sox 9 expression during gonadal development implies a conserved role for the gene in testis differentiation in mammals and birds. Nat. Genet. 1996, 14: $62-68$.

Morikawa, N., Clarke, T.R., Novina, C.D., Watanabe, K., Haqq, C., Weiss, M., Roy, A.L., Donahoe, P.K. Human Müllerian inhibiting substance promoter contains a functional TFII-I-binding initiator. Biol. Reprod. 2000, 63: 10751083.

Morohashi, K., Zanger, U. M., Honda, S., Hara, M., Waterman, M. R. and Omura, T. Activation of CYP11A and CYP11B gene promoters by the steroidogenic cell-specific transcription factor, Ad4BP. Mol. Endocrinol. 1993, 7: 1196-1204.

Muscatelli F, Strom T, Walker A, Zanaria E, Recan D, Meindl A, Bardoni B, Guioli S, Zehetner G, Rabl W, Schwarz H, Kaplan J, Camerino G, Meitinger T, Monaco A. Mutations in the $D A X-1$ gene give rise to both $\mathrm{X}$-linked adrenal hypoplasia congenita and hypogonadotropic hypogonadism. Nature, 1994, 372: 672-676.

Nachtigal, M. W., Y. Hirokawa, D. L. Enyeart-VanHouten, J. N. Flanagan, G. D. Hammer, and H. A. Ingraham. Wilms' tumor 1 and Dax-1 modulate the orphan nuclear receptor SF-1 in sex-specific gene expression. Cell, 1998, 93:445-454. 
Nagahara H, Vocero-Akbani AM, Snyder EL, Ho A, Latham DG, Lissy NA, Becker-Hapak M, Ezhevsky SA, Dowdy SF. Transduction of full-length TAT fusion proteins into mammalian cells: TAT-p27Kip1 induces cell migration. Nature Med. 1998, 4: 1449-1452.

Nagamine CM, Chan K, Kozak CA, Lau Y-F. Chromosome mapping and expression of a putative testis-determining gene in mouse. Science, 1989 , 243:80-83.

Nasrin, N., Buggs, C., Kong, X. F., Carnazza, J., Goebl, M. and Alexander Bridges, M. DNA-binding properties of the product of the testisdetermining gene and a related protein. Nature, 1991, 354: 317-320.

Natesan, S. and Gilman, M. Z. DNA bending and orientationdependent function of YY1 in the c-fos promoter. Genes Dev. 1993, 7: 2497-2509.

Nef S, Schaad O, Stallings NR, Cederroth CR, Pitetti JL, Schaer G, Malki S, Dubois-Dauphin M, Boizet-Bonhoure B, Descombes P, Parker KL, Vassalli JD. Gene expression during sex determination reveals a robust female genetic program at the onset of ovarian development. Dev. Biol. 2005, 287: 361-377. Nef S, Verma-Kurvari S, Merenmies J, Vassalli JD, Efstratiadis A, Accili D, Parada LF. Testis determination requires insulin receptor family function in mice. Nature, 2003, 426: 291-295.

Ng LJ, Wheatley S, Muscat GE, Conway-Campbell J, Bowles J, Wright E, BellDM,TamPP, Cheah KS,KoopmanP. SOX9 binds DNA, activates transcription, and coexpresses with type II collagen during chondrogenesis in the mouse. Dev. Biol. 1997, 183: 108-121.

Odor DL, Blandau RJ. Ultrastructural studies on fetal and early postnatal mouse ovaries. I. Histogenesis and organogenesis. Am. J. Anat. 1969, 124: 163-186. Oh HJ, Li Y, Lau YF. Sry associates with the heterochromatin protein 1 complex by interacting with a KRAB domain protein. Biol. Reprod. 2005, 72: 407-415. Ottolenghi C, Moreira-Filho C, Mendonca BB, et al. Absence of mutations involving the LIM homeobox domain gene $L H X 9$ in 46 , XY gonadal agenesis and dysgenesis. J. Clin. Endocrinol. Metab. 2001, 86: 2465-2469.

Ottolenghi C, Omari S, Garcia-Ortiz JE, Uda M, Crisponi L, Forabosco A, Pilia 
G, Schlessinger D. Fox12 is required for commitment to ovary differentiation. Hum. Mol. Genet. 2005, 14: 2053- 2062.

Pace HC, Brenner C: Feminizing chicks: a model for avian sex determination based on titration of Hint enzyme activity and the predicted structure of an AswHint heterodimer. Genome Biology, 2003, 4:R18

Pailhoux E, Vigier B, Vaiman D, Servel N, Chaffaux S, Cribiu EP, Cotinot C.

Ontogenesis of female-to-male sex-reversal in XX polled goats. Dev. Dyn. 2002, 224: $39-50$.

Pailhoux, E., Vigier, B., Chaffaux, S., Servel, N., Taourit, S., Furet, J.P., Fellous, M., Grosclaude, F., Cribiu, E.P., Cotinot, C. and Vaiman, D.A. 11.7 kb deletion triggers intersexuality and polledness in goats. Nat. Genet. 2001, 29, 453-458. Palmer SJ, Burgoyne PS. In situ analysis of fetal, prepuberal and adult $\mathrm{XX} \times \mathrm{XY}$ chimaeric mouse testes: Sertoli cells are predominantly, but not exclusively, XY. Development, 1991a, 112: 265-268.

Palmer SJ, Burgoyne PS. XY follicle cells in the ovaries of $\mathrm{XO} / \mathrm{XY}$ and XO/XY/XXY mosaic mice. Development, 1991, 111: 1017-1019.

Paranko, J., L. J. Pelliniemi, A. Vaheri, J. M. Foidart, and, T. Lakkala-Paranko. Morphogenesis and fibronectin in sexual differentiation of rat embryonic gonads. Differentiation, Suppl. 1983, 23: 72-81.

Park, S. Y., Meeks J. J., Raverot G., Pfaff L. E., Weiss J., Hammer G. D. , JamesonJ. L. Nuclear receptors Sf1 and Dax 1 function cooperatively to mediate somatic cell differentiation during testis development. Development. 2005, 132: 2415-2423.

Parker, K. L., Rice, D. A., Lala, D. S., Ikeda, Y., Luo, X., Wong, M., Bakke, M., Zhao, L., Frigeri, C., Hanley, N. A. et al. Steroidogenic factor 1: an essential mediator of endocrine development. Recent Prog. Horm. Res. 2002, 57: 19-36. Pedersen, J.F. Ultrasound evidence of sexual difference in fetal size in first trimester. Br. Med. J. 1980, 281: 1253.

Pelletier, J., M. Schalling, A. J. Buckler, A. Rogers, D. A. Haber, and D. Housman. Expression of the Wilms' tumor gene WT1 in the murine urogenital system. Genes Dev. 1991, 5:1345-1356. 
Penalva LOF, Sanchez L: RNA binding protein sex-lethal (sxl) and control of Drosophila sex determination and dosage compensation. Microbiol Mol Biol Rev 2003, 67:343-359.

Pepling ME, Spradling AC. Female mouse germ cells form synchronously dividing cysts. Development, 1998, 125: 3323-3328.

Peters, H. Migration of gonocytes into the mammalian gonad and their differentiation. Philos. Trans. R Soc. Land. B Biol. sci. 1970, 9: 91-101. Phillips DJ, de Kretser DM. Follistatin: a multifunctional regulatory protein. Front Neuroendocrinol. 1998,19:287-322.

Polanco JC, Koopman P. Sry and the hesitant beginnings of male development. Dev. Biol. 2007, 302: 13-24.

Pontiggia A, Rimini R, Harley VR, Goodfellow PN, Lovell Badge R, Bianchi ME. Sex-reversing mutations affect the architecture of SRY-DNA complexes. EMBO J. 1994, 13: 6115-6124.

Poulat F, Barbara PS, Desclozeaux M, Soullier S, Moniot B, Bonneaud N, Boizet B, Berta $P$. The human testis determining factor SRY binds a nuclear factor containing PDZ protein interaction domains. J. Biol. Chem. 1997, 272: 7167-7172.

Poulat, F., Soullier, S., Gozé, C., Heitz, F., Calas, B. and Berta, P. Description and functional implications of a novel mutation in the sex determining gene $S R Y$. Human Mutation, 1994, 3: 200-204.

Pritchard-Jones, K., S. Fleming, D. Davidson, W. Bickmore, D. Porteous, C. Gosden, J. Bard, A. Buckler, J. Pelletier, D. E. Housman, V. van Heyningen, and N. Hastie. The candidate Wilms' tumor gene is involved in genitourinary development. Nature, 1990, 346:194-197.

Puoti A, Pugnale P, Belfiore M, Sclappi AC, Saudan Z: RNA and sex determination in Caenorhabditis elegans. EMBO reports 2001, 2:889-904. Purohit A, Singh A, Ghilchik M, Serlupi-Crescenzi O, Reed M: Inhibition of IL6+IL- 6 soluble receptor-stimulated aromatase activity by the IL- 6 antagonist, Sant 7, in breast tissue derived fibroblasts. British Journal of Cancer 2003, 88:630-635. 
Rice, D. A., Mouw, A. R., Bogerd, A. M. and Parker, K. L. A shared promoter element regulates the expression of three steroidogenic enzymes. Mol. Endocrinol. 1991, 5: 1552-1561.

Roberts LM, Visser JA, Ingraham HA. Involvement of a matrix metalloproteinase in MIS-induced cell death during urogenital development. Development, 2002, 129: 1487-1496.

Ross A., F. Cuzin, V. van Heyningen, and N. D. Hastie. Subnuclear localization of WT1 in splicing or transcription factor domains is regulated by alternative splicing. Cell, 1995, 81:391-401.

Ross, A. J., Tilmann, C., Yao, H., MacLaughlin, D. \& Capel, B. AMH induces mesonephric cell migration in XX gonads. Mol. Cell. Endocrinol. 2003, 211:17.

Salvi, R., Gomez, F., Fiaux, M., Schorderet, D., Jameson, J. L., Achermann, J. C., Gaillard, R. C. and Pralong, F. P. Progressive onset of adrenal insufficiency and hypogonadism of pituitary origin caused by a complex genetic rearrangement within DAX-1. J. Clin. Endocr. Metab. 2002, 87: 4094-4100. Sarre SD, Georges A, Quinn A: The ends of a continuum: genetic and temperature-dependent sex determination in reptiles. BioEssays 2004, 26:639645.

Schartl M: Sex chromosome evolution in non-mammalian vertebrates. Curr Opin Genet Dev 2004, 14:634-641.

Schmahl J, Capel B: Cell proliferation is necessary for the determination of male fate in the gonad. Dev. Biol. 2003, 258: 264-276.

Schmahl J, Eicher E, Washburn L, Capel B. Sry induces cell proliferation in the mouse gonad. Development 127: 65-73, 2000.

Schmidt D, Ovitt CE, Anlag K, Fehsenfeld S, Gredsted L, Treier AC, Treier M. The murine winged-helix transcription factor Foxl2 is required for granulosa cell differentiation and ovary maintenance. Development, 2004, 131: 933-942. Schwarze SR, Ho A, Vocero-Akbani A, Dowdy SF. In vivo protein transduction: delivery of a biologically active protein into the mouse. Science 1999, 285 : 1569-1572. 
Scott, W.J., Holson, J.F. Weight differences in rat embryos prior to sexual differentiation. J. Embryol. Exp. Morphol. 1977, 40: 259-263.

Sekido R, Bar I, Narvaez V, Penny G, Lovell-Badge R. SOX9 is up-regulated by the transient expression of SRY specifically in Sertoli cell precursors. Dev Biol, 2004, 274: 271-279.

Seller, M.J., Perkins-Cole, K.J. Sex difference in mouse embryonic development at neurulation. J. Reprod. Fertil. , 1987, 79: 159-161.

Shahid M, Dhillion VS, Jain N, Hedau S, Diwakar S, Sachdeva P, Batra S, Das

BC, Husain SA. Two new novel point mutations localized upstream and downstream of the HMG box region of the SRY gene in three Indian 46,XY females with sex reversal and gonadal tumour formation. Mol. Hum. Reprod. 2004, 10: 521-526.

Shahid M, Dhillon VS, Aslam M, Husain SA. Three new novel point mutations localized within and downstream of high-mobility group-box region in SRY gene in three Indian females with Turner syndrome. J. Clin. Endocrinol. Metab. 2005, 90: 2429-2435.

Shawlot W, Behringer RR. Requirement for Lim1 in headorganizer function. Nature, 1995, 374: 425-430.

Shen, W. H., Moore, C. C., Ikeda, Y., Parker, K. L. and Ingraham, H. A. Nuclear receptor steroidogenic factor 1 regulates the Müllerian inhibiting substance gene: a link to the sex determination cascade. Cell, 1994, 77: 651-661.

Shibata K, Takase M, Nakamura M: The Dmrtl expression in sexreversed gonads of amphibians. Gen. Comp. Endocrinol. 2002, 127:232-241.

Simpson E, Davis S: Minireview: Aromatase and the Regulation of Estrogen Biosynthesis - Some New Perspectives. Endocrinology 2001, 142:4589-4594. Smith CA, McClive PJ, Hudson Q, Sinclair AH. Male-specific cell migration into the developing gonad is a conserved process involving PDGF signalling. Dev. Biol. 2005, 284: 337-350.

Smith CA, Sinclair AH: Sex determination: insights from the chicken. BioEssays 2004, 26:120-132.

Soane L., Fiskum G. TAT-mediated endocytotic delivery of the loop deletion 
Bcl-2 protein protects neurons against cell death, J. Neurochem. 2005, 95: 230243.

Stalhut JK, Cowan DP: Single-locus complementary sex determination in the inbreeding wasp Euodynerus foraminatus Saussure (Hymenoptera: Vespidae). Heredity 2004, 92:189-196.

Stark, K., Vainio, S., Vassileva, G., \& McMahon, A. P. Epithelial transformation of metanephric mesenchyme in the developing kidney regulated by Wnt-4. Nature, 1994, 372: 679- 683.

Stothard P, Pilgrim D: Sex determination gene and pathway evolution in nematodes. BioEssays 2003, 25:221-231.

Südbeck P, Scherer G. Two independent nuclear localization signals are present in the DNA-binding high mobility group domains of SRY and SOX9. J. Biol. Chem. 1997, 272: 27848-27852.

Südbeck P, Schmitz ML, Baeuerle PA, SchererG. Sex reversal by loss of the Cterminal transactivation domain of human SOX9. Nat. Genet. 1996, 13: 230232.

Suzuki T, Kasahara M, Yoshioka H, Morohashi K, Umesono K. LXXLL-related motifs in Dax-1 have target specificity for the orphan nuclear receptors Ad4BP/SF-1 and LRH-1. Mol. Cell. Biol. 2003, 23: 238-249.

Swain A, Lovell-Badge R. Mammalian sex determination: a molecular drama. Genes Dev 1999.13:755-767.

Swain A, Zanaria E, Hacker A, Lovell-Badge R, Camerino G. Mouse Dax I expression is consistent with a role in sex determination as well as adrenal and hypothalamus function. Nat. Genet. 1996, 12: 404-409.

Tabarin, A., Achermann, J. C., Recan, D., Bex, V., Bertagna, X., ChristinMaitre, S., Ito, M., Jameson, J. L. and Bouchard, P. A novel mutation in DAX1 causes delayed-onset adrenal insufficiency and incomplete hypogonadotropic hypogonadism. J. Clin. Invest. 2000, 105: 321-328.

Taketo T, Lee CH, Zhang J, Li Y, Lee CY, Lau YF. Expression of SRY proteins in both normal and sex-reversed XY fetal mouse gonads. Dev. Dyn. 2005, 233: 612-622. 
Thevenet L, Albrecht KH, Malki S, Berta P, Boizet-Bonhoure B, Poulat F. NHERF2/SIP-1 interacts with mouse SRY via a different mechanism than human SRY. J. Biol. Chem. 2005, 280: 38625-38630.

Tilmann C, Capel B. Mesonephric cell migration induces testis cord formation and Sertoli cell differentiation in the mammalian gonad. Development, 1999; 126: $2883-2890$

Tilmann C, Capel B: Mesonephric cell migration induces testis cord formation and Sertoli cell differentiation in the mammalian gonad. Development 1999, 126: $2883-2890$.

Tommerup N, Schempp W, Mienecke P, Pedersen S, Bolund L, Brandt C, Goodpasture C, Guldberg P, Held KR, Reinwein H, Saaugstad OD, Scherer G, Skjeldal O, Toder R, Westvik J, vander Hagen CB, Wolf U. Assignment of an autosomal sex reversal locus (SRA1) and campomelic dysplasia (CMPD1) to 17q24.3-q25.1. Nat. Genet. 1993, 4: 170-174.

Torrey, T. W. The development of the urinogenital system of the albino rat. II. The gonads. Am. J. Anat. 1945, 76: 375-397.

Tremblay, J.J., Viger, R.S. Transcription factor GATA-4 enhances Mullerian inhibiting substance gene transcription through a direct interaction with the nuclear receptor SF-1. Mol. Endocrinol. 1999, 13: 1388- 1401.

Uda M, Ottolenghi C, Crisponi L, Garcia JE, Deiana M, Kimber W, Forabosco A, Cao A, Schlessinger D, Pilia G. Fox12 disruption causes mouse ovarian failure by pervasive blockage of follicle development. Hum. Mol. Genet. 2004, 13: 1171-1181.

Ungar,A. R.,Kelly,G. M.,\&Moon, R.T. Wnt4 affects morphogenesis when misexpressed in the zebrafish embryo. Mech. Dev. 1995, 52: 153-164. Upadhyay, S., J. M. Luciani, Zamboni L. The role of the mesonephros in the development of the indifferent gonads and ovaries of the mouse. Ann. Bid Anim. Biochim Biophys. 1979, 19: 1179-1196.

Vainio, S., Heikkila, M., Kispert, A., Chin, N., McMahon, A.P. Female development in mammals is regulated by Wnt-4 signalling. Nature, 1999, 397: 405- 409 . 
Val, P., Lefrancois-Martinez, A. M., Veyssiere, G. and Martinez, A. SF-1 a key player in the development and differentiation of steroidogenic tissues. Nucl. Recept. 2003, 1: 8 .

Vives E., Brodin P., Lebleu B. A truncated HIV-1 Tat protein basic domain rapidly translocates through the plasma membrane and accumulates in the cell nucleus, J. Biol. Chem. 1997, 272: 16010-16017.

Wagner T, Wirth J, Meyer J, Zabel B, Held M, Zimmer J, Pasantes J, Bricarelli FD, Keutel J, Hustert E, Wolf U, Tommerup N, Schempp W, Scherer G. Autosomal sex reversal and campomelic dysplasia are caused by mutations in and around the SRY-related gene SOX9. Cell, 1994, 79: 1111-1120. Wang, Z. J., Jeffs, B., Ito, M., Achermann, J. C., Yu, R. N., Hales, D. B. and Jameson, J. L. Aromatase (Cyp19) expression is up regulated by targeted disruption of Dax1. Proc. Natl. Acad. Sci. USA, 2001, 98: 7988-7993. Wartenberg, H., Kinsky, I., Viebahn, C., and Schmolke, C. Fine structural characteristics of testicular cord formation in the developing rabbit gonad. J. Electron Microsc. Tech. 1991, 19:133-157.

Wartenberg, H. Differentiation and development of the testis. In: The Testis, Comprehensive Endocrinology, edited by H. Burger and D. de Kretser. New York: Raven, 1981, 39-80.

Wartenberg, H. Human testicular development and the role of the mesonephros in the origin of a dual Sertoli cell system. Andrologia, 1978, 10: 1-21.

Watanabe, K., Clarke, T.R., Lane, A.H., Wang, X., Donahoe, P.K. Endogenous expression of Müllerian inhibiting substance in early postnatal rat Sertoli cells requires multiple steroidogenic factor-1 and GATA-4-binding sites. Proc. Natl. Acad. Sci. USA, 2000, 97: 1624- 1629.

Waters PD., Wallis MC, Marchall Graves JA. Mammalian sex-origin and evolution of the Y chromosome and SRY. Semin. Cell Dev. Biol. 2007 June; 18(3): 398-400.

Wells, A. and Marti, U. Signalling shortcuts: cell-surface receptors in the nucleus? Nat. Rev. Mol. Cell Biol. 2002, 3: 697-702. 
Wennstrom K, Gill C, Crews D: Sex differences in estrogeninduced progesterone and estrogen receptor mRNA in the ventromedial hypothalamus of hatchling whiptail lizards. Developmental Brain Research 2003, 145:151-157. Western PS, Harry JL, Graves JA, Sinclair AH. Temperaturedependent sex determination: upregulation of $S O X 9$ expression after commitment to male development. Dev. Dyn. 1999, 214:171-177.

Wilhelm D, Martinson F, Bradford S, Wilson MJ, Combes AN, Beverdam A, Bowles J, Mizusaki H, Koopman P. Sertoli cell differentiation is induced both cell-autonomously and through prostaglandin signaling during mammalian sex determination. Dev. Biol. 2005, 287: 111-124.

Wilhelm D, Palmer S, Koopman P: Sex Determination and Gonadal Development in Mammals. Physiol. Rev. 2007, 87:1-28.

Wilhelm, D., Hiramatsu R., Mizusaki H., Widjaja L.,Combes A.N., Kanai Y and Koopman P. SOX9 Regulates Prostaglandin D Synthase Gene Transcription in Vivo to Ensure Testis Development. j. Biol. Chem. 2007a, 282: 10553-10560. Wilson, T. E., Fahrner, T. J. and Milbrandt, J. The orphan receptors NGFI-B and steroidogenic factor 1 establish monomer binding as a third paradigm of nuclear receptor-DNA interaction. Mol. Cell. Biol. 1993, 13: 5794-5804.

Yao HH, Matzuk MM, Jorgez CJ, Menke DB, Page DC, Swain A, Capel B.

Follistatin operates downstream of Wnt4 in mammalian ovary organogenesis. Dev. Dyn. 2004, 230: 210-215.

Yao, H. H., Whoriskey, W. and Capel, B. Desert Hedgehog/Patched 1 signaling specifies fetal Leydig cell fate in testis organogenesis. Genes. Dev. 2002, 16: 1433-1440.

Yu, R. N., Ito, M., Saunders, T. L., Camper, S. A. and Jameson, J. L. Role of Ahch in gonadal development and gametogenesis. Nat. Genet. 1998, 20: 353357.

Zamboni L, Upadhyay S. Germ cell differentiation in mouse adrenal glands. J. Exp. Zool. 1983, 228: 173-193.

Zamboni, L., Upahyay S., Bezard J.\& Mauleon. P. The role of the mesonephros in the development of the sheep testis and its current pathways in: Development 
and Function of Reproductive Organs, edited by A. G. Byskov and H. Peters. Amsterdam: Excerpta Med., 1981, p. 31-40.

Zanaria E, Muscatelli F, Bardoni B, Strom TM, Guioli S, Guo W, Lalli E, Moser C, Walker AP, McCabe ERB, Meltinger T, Monaco AP, Sassone-Corsi P, Camerino G. An unusual member of the nuclear hormone receptor superfamily responsible for Xlinked adrenal hypoplasia congenita. Nature, 1994, 372: 635641.

Zayed A: Effective population size in Hymenoptera with complementary sex determination. Heredity 2004, 93:627-630.

Zazopoulos E, Lalli E, Stocco DM, Sassone-Corsi P. DNA binding and transcriptional repression by DAX-1 blocks steroidogenesis. Nature, 1997, 390: 311-315.

Zhang H, Thomsen JS, Johansson L, Gustafsson JA, Treuter E. DAX-1 functions as an LXXLL-containing corepressor for activated estrogen receptors. J. Biol. Chem. 2000, 275: 39855-39859. 


\section{Figure legends}

Figure 1. Genetic pathways with a characterized functional role in the divergent development of $X X$ and $X Y$ gonads. (Adapted from Brennan \& Capel, 2004)

Several factors are required between 10.5-11.5 days post coitum (dpc) for the outgrowth of the early bipotential gonad (Sf1, Wt1, Lhx9, M33, Emx2, lgf1rl/r/lirr).

Between 10.5-12.0 dpc, GATA4/FOG2 and WT1+KTS are implicated in the activation of Sry expression in the XY gonad. Sry expression diverts the $X Y$ gonad towards the testis fate. Sox9, Fgf9 and Dax1 are implicated in the early steps of the male pathway after the initiation of Sry expression. Downstream signalling pathways promote the rapid structural changes that characterize early testis development.

By contrast, few morphological changes are apparent in the $X X$ gonad until near birth $(18.5 \mathrm{dpc})$, when ovarian follicles begin to form in the ovarian cortex. Wnt4 and Fst are the only two genes with characterized functions in early ovarian development. 

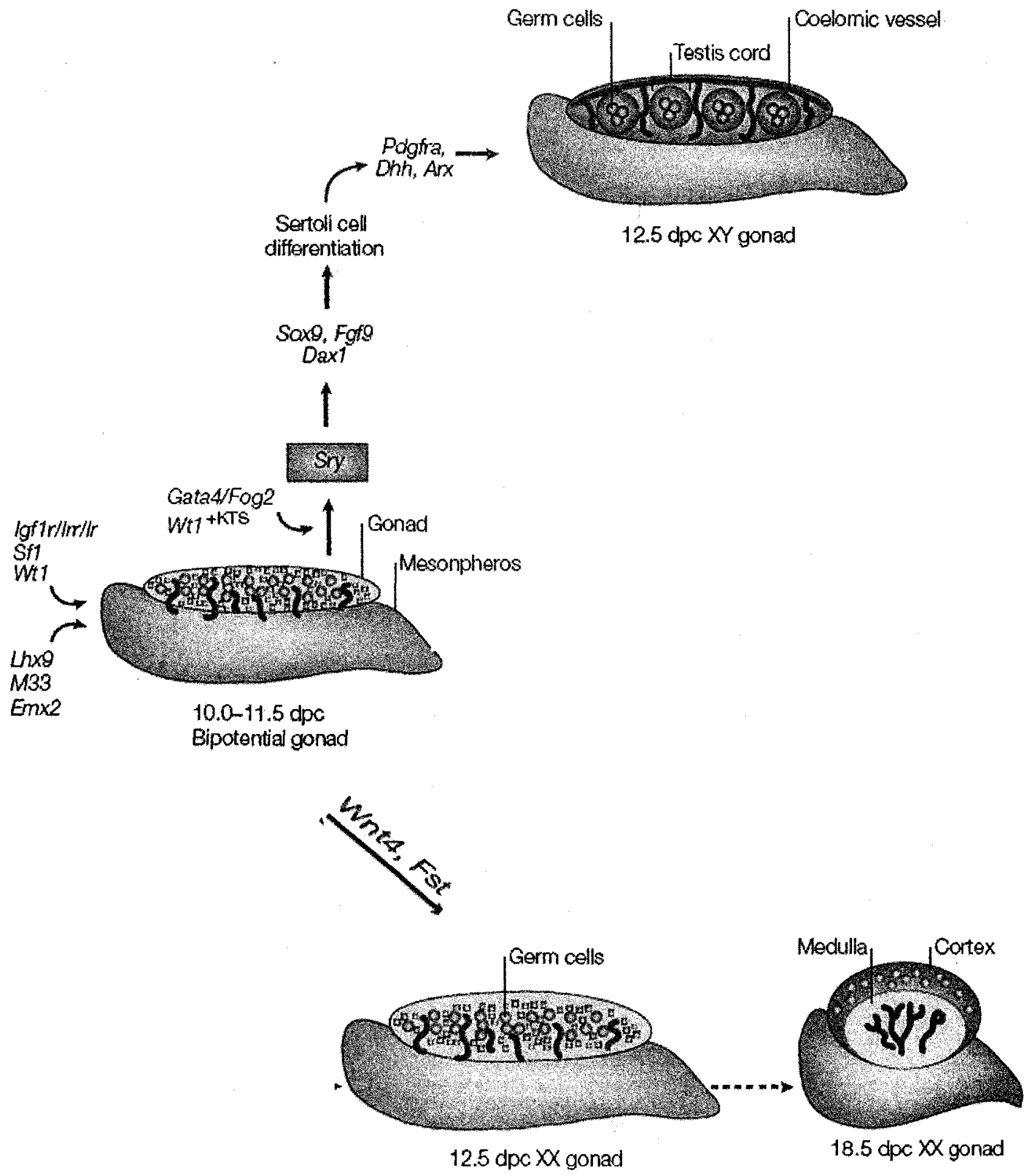
Figure 2. Structure of the SRY protein. (Adapted from Polanco \& Koopman, 2006)

a. Human SRY protein diagram showing the mapping of reported interactions. The HMG domain is represented as a solid box flanked by the $\mathrm{N}$-terminal and $\mathrm{C}$-terminal domains. Numbers indicate amino acid residues. Nuclear localization signals (NLS) interacting with calmodulin or importin $\beta$ are shown in green. Post-translational modifications regulating SRY activity are shown in red, and reported stable interactions with nuclear proteins in blue.

b. Comparison of human and mouse SRY proteins. Level of amino acid homology to human SRY in the HMG box and C-terminal region of the proteins are shown (98\%). The mouse protein contains a large glutamine-rich repetitive region shown as a shaded box. SRY in the subspecies $M . m$. domesticus has a premature stop codon (asterisk) that truncates this domain. Apart from the HMG domain, the bridge region in mouse is the only region homologous to human SRY (47\%). 


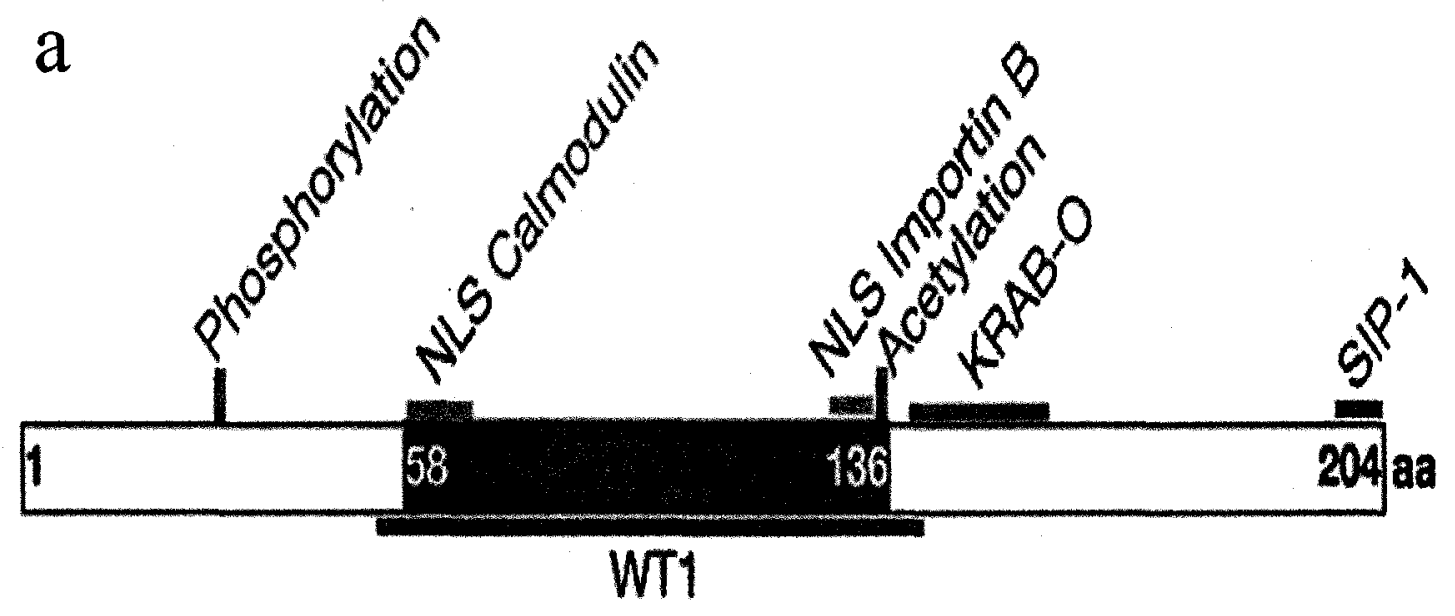

b

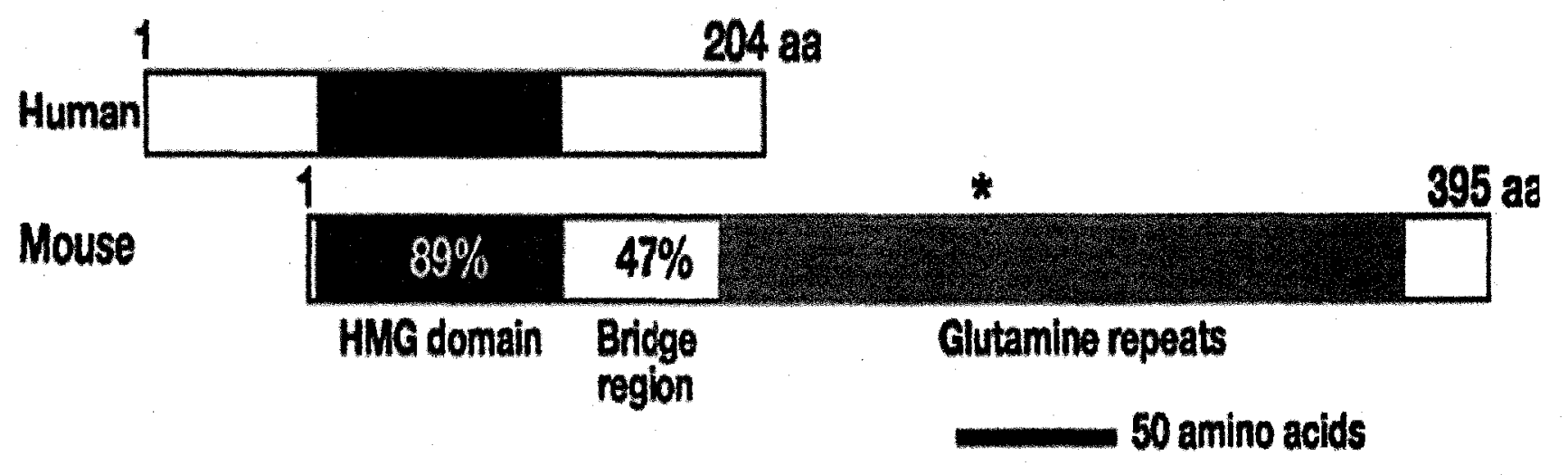


Figure 3. Fetal testes at 11.5-13.5 dpc (in vivo). a-c, double labeling of SOX9 (green) and MIS (red). d-f, double labeling of $\alpha$-laminin (green, invisible when two labeled images were merged) and MIS (red). Counterstained with DAPI (blue). Bar indicates $0.4 \mathrm{~mm}$. Yellow dots are blood.

a \& d. XY urogenital complex at $11.5 \mathrm{dpc}$ (22 ts-stage). a. Several SOX9positive cells were scattered in the anterior region of the genital ridge. $d$. MIS expression was seen in the central region of the genital ridge near the mesonephros.

b \& e. XY urogenital complex at $12.5 \mathrm{dpc}$ (28 ts-stage). Many SOX9-positive cells were scattered in the gonad while MIS-positive cells marked the early phase of testis cord formation.

c \& f. XY urogenital complex at $13.5 \mathrm{dpc}$. Many testis cords were formed with nucleic SOX9 labeling in the peripheral region and cytoplasmic MIS labeling in the central region. 

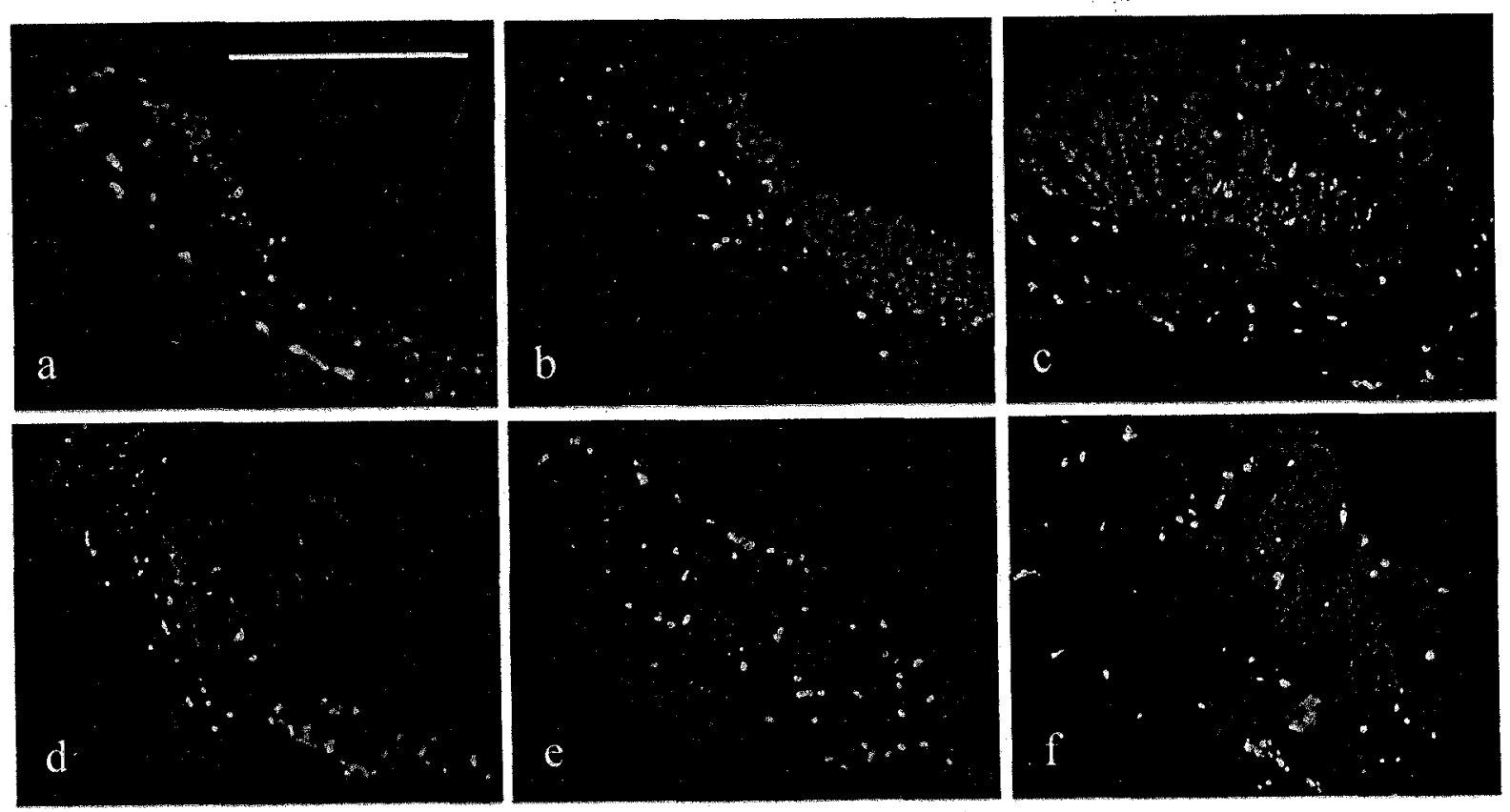
Figure 4. $X Y$ urogenital complexes after culture for 3 days. a-d, double labeling of SOX9 (green) and MIS (red). e-h, double labeling of $\alpha$-laminin (green, invisible when two labeled images were merged) and MIS (red). Counterstained with DAPI (blue). Bar indicates $0.27 \mathrm{~mm}$.

a \& e. Untreated control. Testis cords were well formed with SOX9 and MIS labeling in Sertoli cells.

b \& f. Treatment with $0.6 \%$ DMSO. Intense labeling of SOX9 and MIS were seen in the gonad, but testis cords were not well formed or appeared fragmented.

c \& g. Treatment with 1.8\% DMSO. Several SOX9-positive cells were scattered while MIS labeling was absent in the gonad. Testis cords were not formed. A distinct laminin layer was seen along the surface epithelium.

d \& h. Treatment with $6 \mu \mathrm{g} / \mathrm{ml}$ TAT-HMG dissolved in $1.8 \%$ DMSO. Intense labeling of SOX9 and MIS were seen in the gonad but testis cords were not formed. 


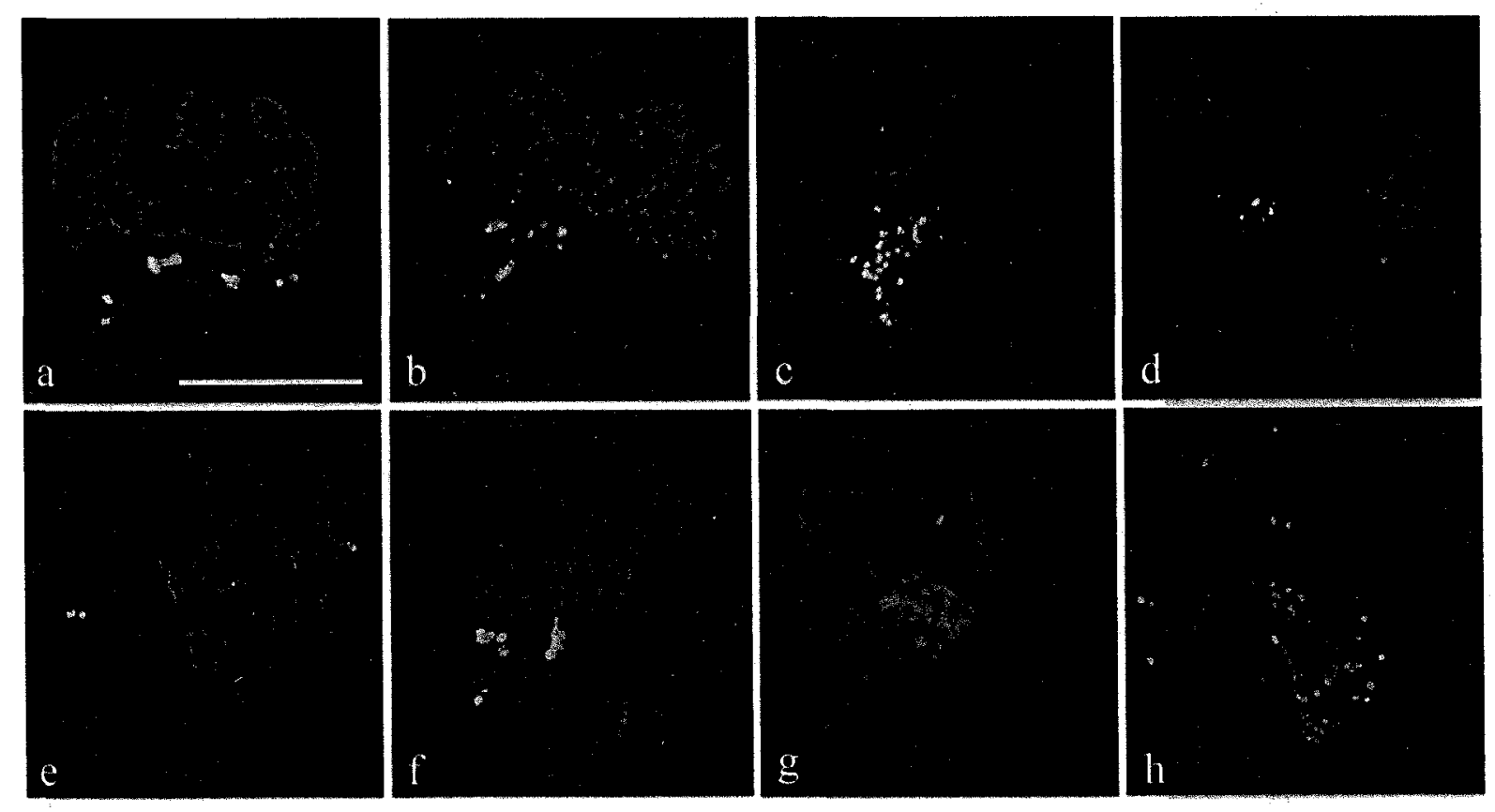


Figure 5. XY urogenital complexes after culture for 3 days. Double labeling of SOX9 (green) and MIS (red). Counterstained with DAPI (blue). Bar indicates $0.4 \mathrm{~mm}$.

a. Untreated control. Testis cords were well formed with SOX9 and MIS labeling in Sertoli cells.

b. Treatment with $1 \mu \mathrm{g} / \mathrm{ml} \mathrm{PGD2}$ in the presence of DMSO. Intense labeling of SOX9 and MIS were seen in the gonad but testis cords were not well formed. 
7
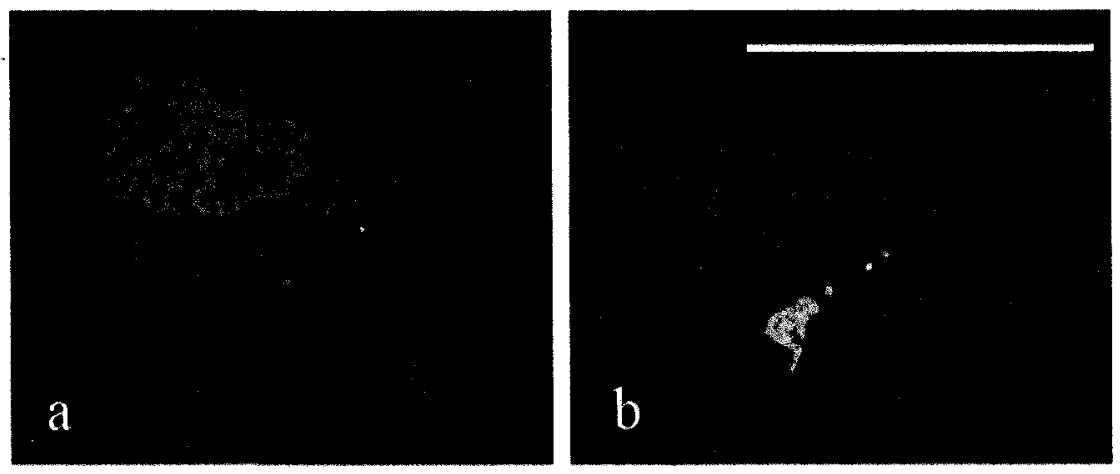
Figure 6. Sections of $X Y$ urogenital complexes after treatment with TATHMG for $\mathbf{2}$ hrs. Immunolabeling of HA (green, HA is a sequence attached to pTAT). Counterstained with DAPI (blue). Bar indicates $0.4 \mathrm{~mm}$.

a. TAT-HMG was mostly concentrated in the nuclei (blue dots) of cells on the surface and $a$ in the cytoplasm of few cells internally within the genital ridge.

b \& c. 5 times magnified of selected parts of a; incorporation of TAT-HMG was seen in the cytoplasm and nucleus of some of the cells on the surface layer. 
7
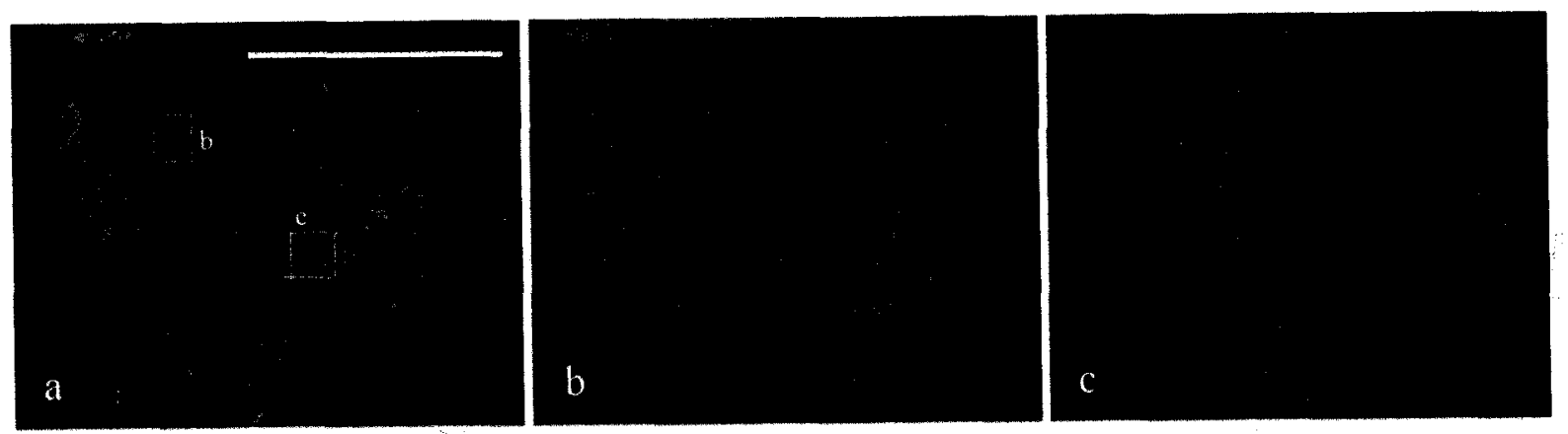
Figure 7. The time course of gonadal differentiation in the $X Y$ urogenital complex with or without $6 \mu \mathrm{g} / \mathrm{ml}$ TAT-HMG treatment in culture. a-d. Double labeling of SRY (green) and MIS (red). e-h. Double labeling of SOX9 (green) and MIS (red). Counterstained with DAPI (blue). Bar indicates $0.4 \mathrm{~mm}$.

a \& e. Untreated control after culture for 1 day. SRY labeling was weaker where MIS labeling was visible (arrows). Intensive SOX9 labeling was seen in the pre-Sertoli cells scattering in the developing testis cords.

b \& f. Untreated control after culture for 2 days. SRY labeling was barely visible while MIS labeling was intense in well-formed testis cords. Intensive SOX9 labeling was seen in the peripheral region of testis cords.

c \& g. Treatment with TAT-HMG for 1 day. SRY labeling was intense while MIS labeling was absent in the gonad. SOX9 labeling was seen in the preSertoli cells scattering all over the gonad.

$d \& h$. Treatment with TAT-HMG for 2 days. Low intensity of SRY labeling was visible over the gonad while MIS labeling was limited to the central region of the gonad. No testis cords were formed. Intense SOX9 labeling was seen in the Sertoli cells scattering all over the gonad. 


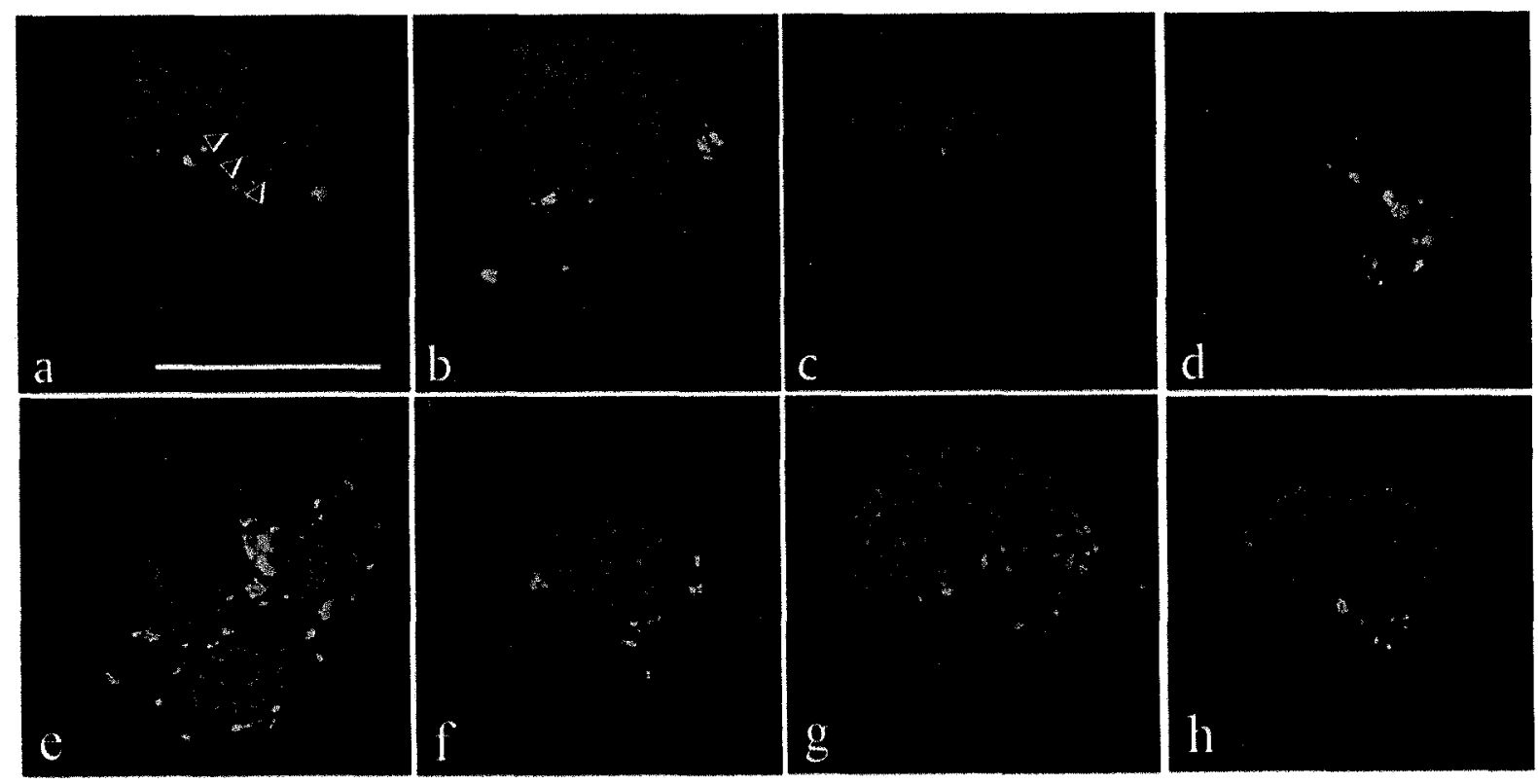


Figure 8. Comparison of Sry, Sox9, and Mis transcript levels in XX and XY urogenital complexes with or without treatment with TAT-HMG. The number in blankets above each column indicates the total number of gonads examined.

a. Sry transcript levels after culture for 1 day. The levels significantly increased $(P<0.05)$ in the $X Y$ urogenital complex after treatment with the higher dosage of TAT-HMG. Sry transcrips were undetectable in the XX urogenital complex.

b. Sox 9 transcript levels after culture for 1 day. The levels significantly decreased $(P<0.01)$ in the XY urogenital complex after treatment with the higher dosage of TAT-HMG. Low levels of Sox9 transcripts were detectable in the XX urogenital complex.

c. Mis transcript levels after culture for 1 day. No difference was found in the XY urogenital complex after treatment with TAT-HMG. Mis transcripts were undetectable in the XX urogenital complex.

d. Sry transcript levels after culture for 3 days. No difference was found in the XY urogenital complex after treatment with TAT-HMG. Sry transcripts were undetectable in the $X X$ urogenital complex.

e. Sox9 transcript levels after culture for 3 days. No difference was found in the $X Y$ urogenital complex after treatment with TAT-HMG. Sox9 transcripts were at the detection limit in the $X X$ urogenital complex.

f. Mis transcript levels after culture for 3 days. No difference was found in the $X Y$ urogenital complex after treatment with TAT-HMG. Mis transcripts were undetectable in the $X X$ urogenital complex. 

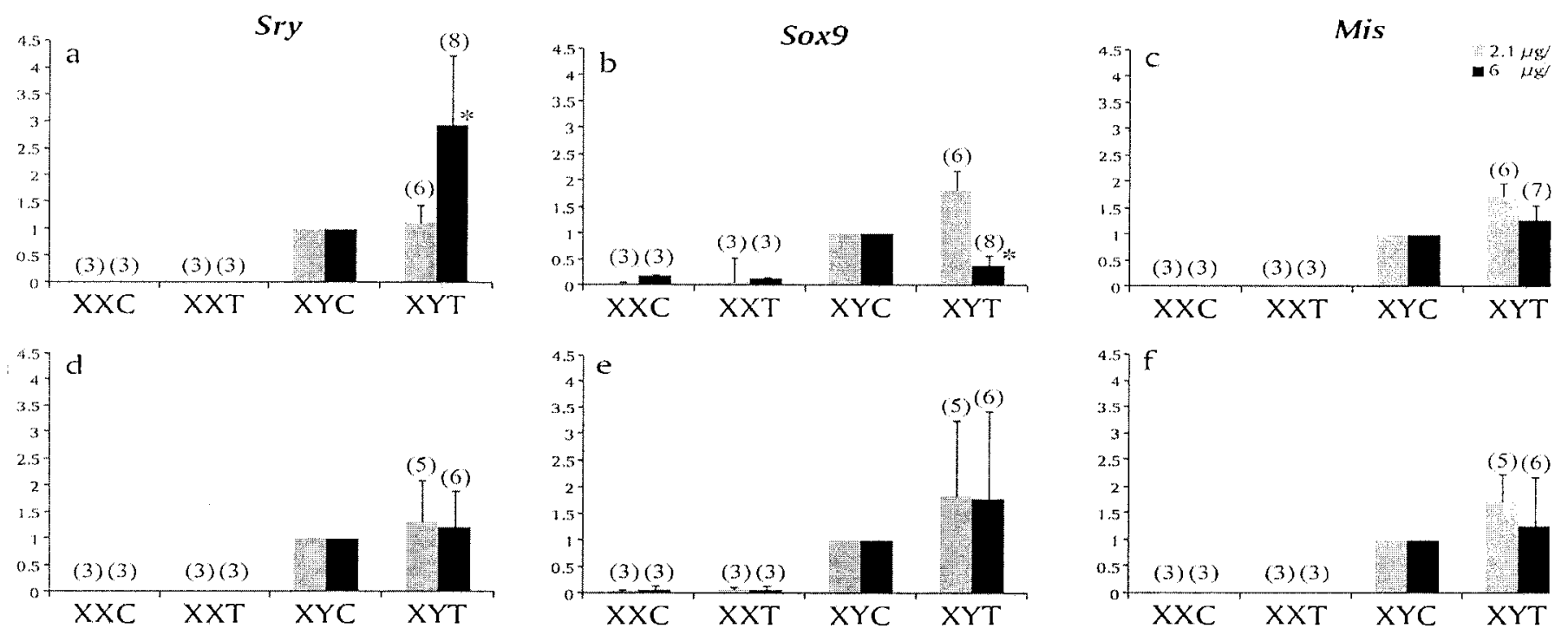
Figure 9. Comparison of Sry, Sox9, and Mis transcript levels in the XY urogenital complex with or without treatment with $1.8 \%$ DMSO for 1 day. Sox 9 and Mis transcript levels significantly decreased $(P<0.05$ and 0.001 , respectively) while Sry transcript levels did not change after treatment ( $n=3$ each). $Y$ axis indicates the amount of fold increase when normalized to 18srRNA transcript levels and then to XY control transcript levels. 


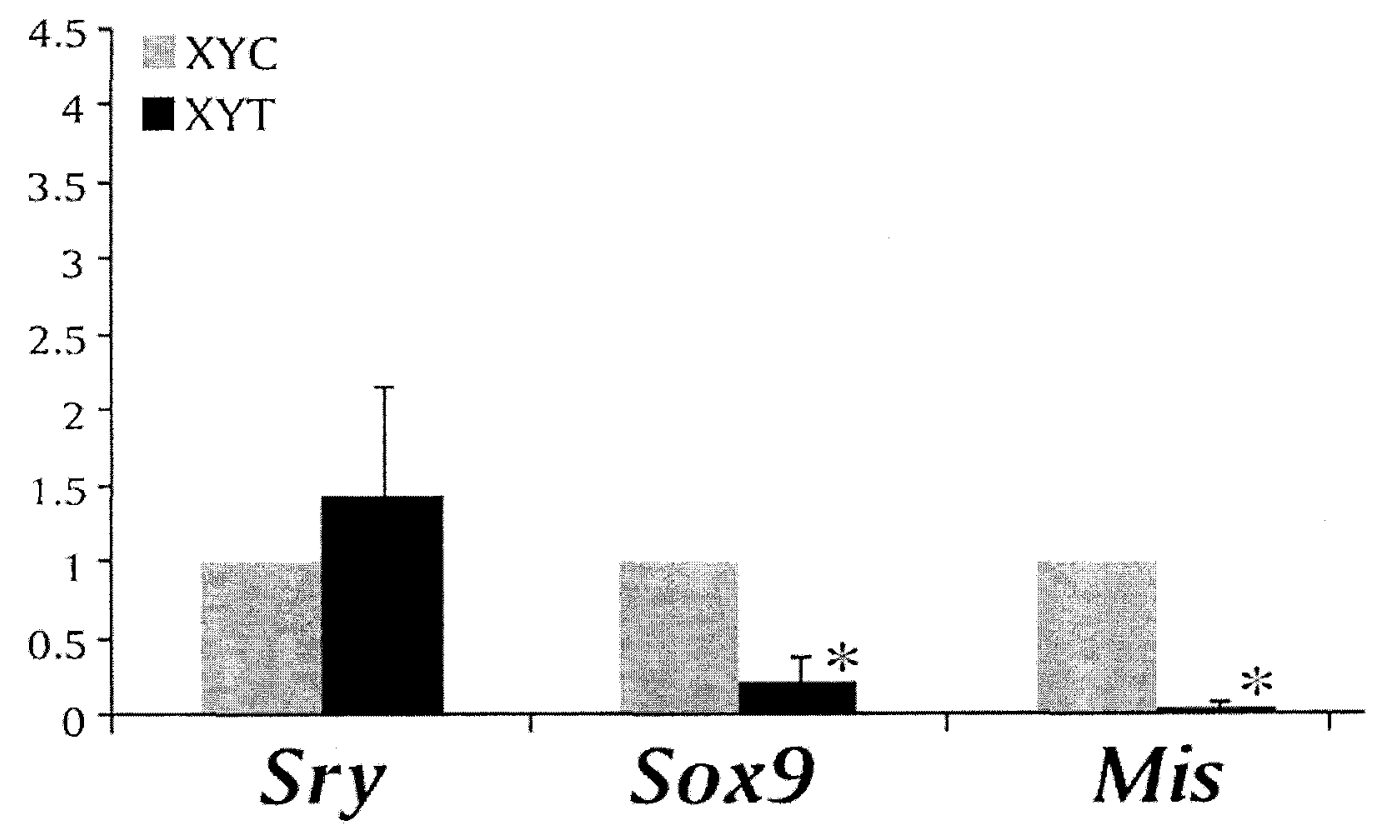


Figure 10. TUNEL detection (green) of cell death in the $\mathrm{XY}$ urogenital complex after culture for 1 day. Counterstained with DAPI (blue). Bar indicates $0.4 \mathrm{~mm}$.

a. Untreated control. TUNEL-positive cells were scattered over the urogenital complex.

b. Treatment with 1.8\% DMSO. An excessive number of TUNEL-positive cells were seen in the mesonephros.

c. Treatment with $6 \mu \mathrm{g} / \mathrm{ml}$ TAT-HMG dissolved in 1.8\% DMSO. A large number of TUNEL-positive cells were seen over the mesonephros. 
$+$
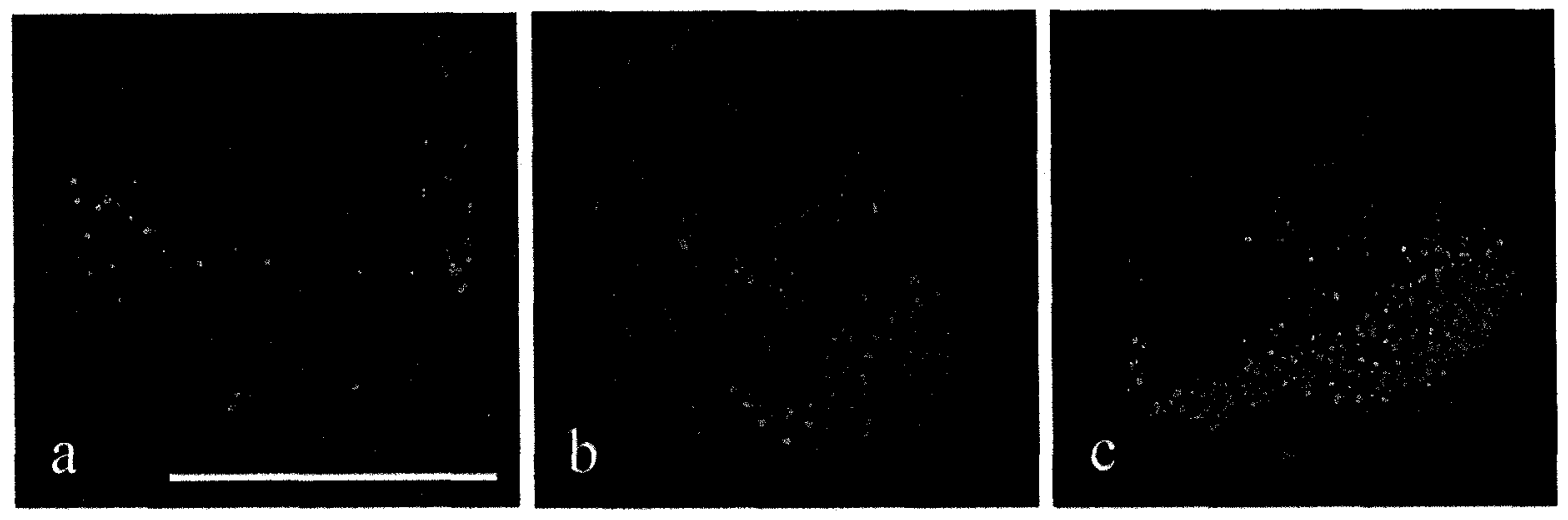